\title{
Evaluation OF Drivers' Behavior Performing a Curve under Mental Workload
}

A thesis submitted in conformity with the requirements for the degree of Master of Science to the Department of Transportation Engineering of the School of Engineering of São Carlos, from the University of São Paulo.

Tutor: Professor Ana Paula Camargo Larocca

\section{SÃo CARLOS}

2016 



\section{Avaliação do Comportamento dos CONDUTORES PARA Realizar uma Curva sob Distração Mental}

Dissertação apresentada à Escola de Engenharia de São Carlos da Universidade de São Paulo para a obtenção do título de Mestre em Ciências pelo Departamento de Engenharia de Transportes.

Orientadora: Profa. Dra. Ana Paula Camargo Larocca

SÃO CARLOS

2016 


\section{AUTORIZO A REPRODUÇÃO TOTAL OU PARCIAL DESTE TRABALHO, POR QUALQUER MEIO CONVENCIONAL OU ELETRÔNICO, PARA FINS DE ESTUDO E PESQUISA, DESDE QUE CITADA A FONTE.}

V251e Eieira, Fábio Sartori
Evaluation of drivers' behavior performing a curve under mental workload / Fábio Sartori Vieira; orientadora Ana Paula Camargo Larocca. São Carlos, 2016.

Dissertação (Mestrado) - Programa de Pós-Graduação em Engenharia de Transportes e Área de Concentração em Infra-Estrutura de Transporte -- Escola de Engenharia de São Carlos da Universidade de São Paulo, 2016.

1. Driving simulator. 2. Driver behavior. 3. Speed profile. 4. Distraction task. 5. Secondary task. 6. Traffic density. 7. Level of service. I. Título. 


\section{FOLHA DE JULGAMENTO}

Candidato: Engenheiro FÁBIO SARTORI VIEIRA.

Título da dissertação: "Comparação do comportamento de motoristas para realizar uma curva sob distração mental".

Data da defesa: 20/04/2016.

\section{Comissão Julgadora:}

Profa. Dra. Ana Paula Camargo Larocca

(Orientadora)

(Escola de Engenharia de São Carlos/EESC)

Profa. Dra. Raquel Alves dos Santos Almqvist

(Universidade de Franca/UNIFRAN)

Prof. Associado Denis Fernando Wolf

(Instituto de Ciências Matemáticas e de Computação/ICMC)

\section{Resultado:}
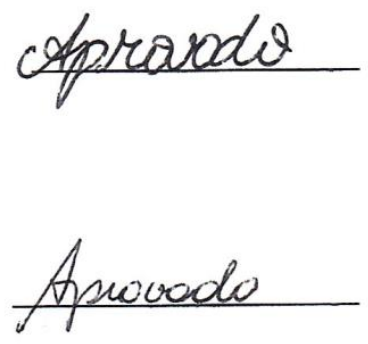

Aprovano

Coordenador do Programa de Pós-Graduação em Engenharia de Transportes: Prof. Associado Paulo Cesar Lima Segantine

Presidente da Comissão de Pós-Graduação:

Prof. Associado Paulo Cesar Lima Segantine 

Dedication

To my niece, Helena,

and those of her generation,

for a safer tomorrow. 



\section{ACKNOWLEDGMENTS}

At the end of this stage, I would like to acknowledge people that contributed in the elaboration of this thesis along these years.

I would first like to thank you for my thesis advisor, Professor Ana Larocca for the trustworthy and for sharing her knowledge. She consistently allowed this paper to be my own work, but steered me in the right direction whenever she thought I needed it.

I would also like to thank the experts who were involved in the validation of this thesis and integrated my master's qualification and commission: Prof. Anabela dos Santos Aleixo Simões, Prof. Denis Fernando Wolf and Prof. Raquel Alves dos Santos Almqvist.

My acknowledgment for CAPES - Comissão de Aperfeiçoamento de Pessoal do Nível Superior) for the financial support that enable this fruitful experience and I thank my colleagues at USP, for their kind company and friendship. 

VIEIRA, F. S. Evaluation of drivers' behavior performing a curve under mental workload. Thesis (Master) - Escola de Engenharia de São Carlos, Universidade de São Paulo, São Carlos, 2016.

\begin{abstract}
Driving under distraction may lead drivers to wrong actions that can result in serious accidents. The objective of this thesis was to apply a driving simulator to verify variations in drivers' behavior while driving. Behavior to drive on a curve was measured by variation in drivers' speed profile in a virtualized highway. The comparison was performed between two identical simulations, one involving drivers distracted with a mental workload, and other in which they were full aware of driving task. 54 volunteer drivers took part in this study, which was divided into 4 stages. 17 drivers performed the distraction test known as PASAT, and results showed that distracted drivers did not recognize the beginning of the curve and drove through it at speeds higher than those when they were fully aware. Moreover, driving performance was increased when drivers were aware of driving, thereby hitting high speeds in tangents, but perceiving curves in advance to reduce acceleration. This study confirms that driving simulators are beneficial in discovering drivers' behavior exposed to activities that could be highly risky if driving in real situations.
\end{abstract}

Keywords: driving simulator; driver behavior; speed profile; distraction; secondary task; traffic density; level of service. 

VIEIRA, F. S. Evaluation of drivers' behavior performing a curve under mental workload. Dissertação (Mestrado) - Escola de Engenharia de São Carlos, Universidade de São Paulo, São Carlos, 2016.

\section{Resumo}

A distração durante a atividade de direção pode levar o condutor de veículos automotores a cometer falhas, que podem ocasionar até mesmo acidentes graves. Este estudo aborda a utilização de simuladores de direção para verificar variações no comportamento de motoristas ao realizar a atividade de direção, distraídos ou com plena atenção na condução do veículo. O comportamento é medido pela variação no perfil de velocidade dos condutores para desenvolver uma curva considerada perigosa em uma rodovia simulada em ambiente virtual. A variação de velocidade deste perfil é comparada entre duas simulações idênticas, onde em uma delas os condutores estão distraídos com um teste que proporciona estresse mental e, na outra, estão com plena atenção à direção. 54 condutores fizeram parte deste estudo dividido em 3 etapas. 17 participantes realizaram o teste de distração conhecido como PASAT, e a análise dos resultados mostram que, distraídos, os condutores não perceberam o início da curva e desenvolveram velocidades maiores durante seu trajeto. Além disso, quando estavam com plena atenção à atividade de direção, o desempenho dos condutores foi melhor, atingindo velocidades maiores nas tangentes, mas percebendo as curvas antecipadamente e reduzindo suas velocidades antes de iniciar esses trechos.

Palavras-chave: Simulador de direção; comportamento dos motoristas; Perfil de velocidade; distração; atividade secundária; nível de serviço. 



\section{LIST OF ABBREVIATIONS}

$\begin{array}{ll}\text { AADT } & \text { Average Annual Daily Traffic } \\ \text { ADAS } & \text { Advanced driver assistance systems } \\ \text { C-00 } & \text { Curve identification in selected stretch } \\ \text { C-14 } & \text { Stretch of BR-116 comprising the curve on KM514+800 } \\ \text { EEG } & \text { Electroencephalography } \\ \text { FOV } & \text { Field of view } \\ \text { LOS } & \text { Level of Service } \\ \text { PASAT } & \text { Paced Auditory Serial Addition Test } \\ \text { V } 85 & \text { 85o percentile of speed developed in stretch } \\ \text { p } & \text { p-Value of Significance test } \\ \text { PSAT } & \text { Paced Serial Addition Test } \\ \text { w/ } & \text { with } \\ \text { w/0 } & \text { without }\end{array}$





\section{LIST OF FIGURES}

Figure 1. Flow versus density graph. The shaded zone represents the moment when drivers change from a free flow situation to a car following synchronized flow (Adapted from KERNER, 2012)

Figure 2. Relationship between demand and performance (MEISTER, 1976)

Figure 3. Ilustration of simulator's cockpit and projection screens. Additionally, 4 eye tracking camera systems captures eye movements.

Figure 4. Car crash statistics identified by curves

Figure 5. Aerial view of simulated C-14 geometry

Figure 6. Stretch's profile and curve's identification (C14)

Figure 7. Example of traffic in the three different levels of service

Figure 8. Variations in the average speed according to the level of service.

Figure 9. Average speed of Group 2 in different LOS scenarios.

Figure 10. Average speed variation from point to point in different traffic densities 31

Figure 11. Driver's situation performing the curve, according to the traffic ahead 32

Figure 12. Average speed according to curve flow

Figure 13. Average speed according to LOS, considering car following flows

Figure 14. Average speed according to LOS traffic and considering only free flow 35 Figure 15. Examples of free flow, with or without vehicles in other lanes and headway requirement achieved

Figure 16. Example of car following flow

Figure 17. Speed variation from actual position to next site

Figure 18. Speed profiles comparing all drivers' simulations without workload with results in the PASAT

Figure 19. Speed profiles comparing drivers without workload with the test application only for free flow simulations 
Figure 20. Driver's FOV at curve with corresponding time for each element (a) without mental workload and (b) answering the PASAT $\quad 41$

Figure 21. Speed profile according to sign improvements 43

Figure 22. Same traffic density configuration at two different situations: (a) with the driver in the middle of traffic and (b) at free flow between two high density traffic 46 Figure 23. An example of erroneous categorization. A free flow driver at the beginning of the curve is closed by a trucker some seconds later, leading to a car following situation.

Figure 24. Simulation of curve signaling from $500 \mathrm{~m}$ before in (a) previous scenario and (b) improved signaling 


\section{LIST OF TABLES}

Table 1. Drivers' answer about the reason of accidents

Table 2. Length of stretches, total of accidents and radius for each curve on segment

22

Table 3. Comparison of level of services according to flow, speed and comfort (adapted from AASHTO, 2010)

Table 4. Variables identifications for groups 1 and 2

Table 5. Drivers' speed variation in free flow from one position to the next

Table 6. Average speed, total of gear and lane changes for simulations.

Table 7. Total time of elements' eye tracking observations during curve trajectory 42

Table 8. Participants' FOV from eye tracking system 42

Table 9. Results from Presence Questionnaire 



\section{CONTENTS}

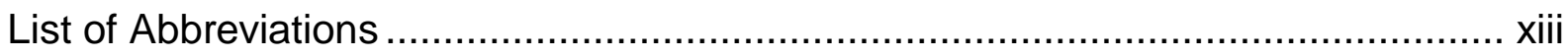

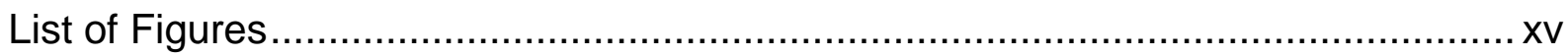

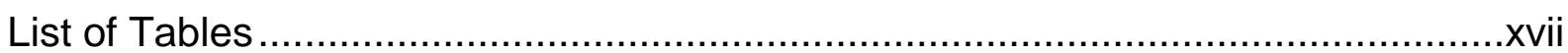

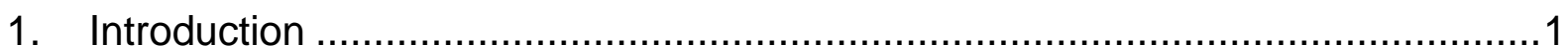

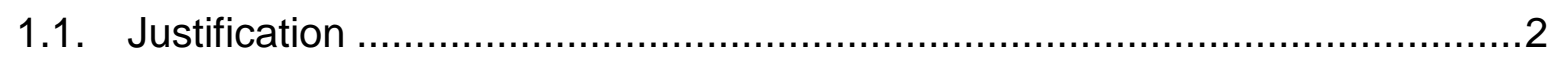

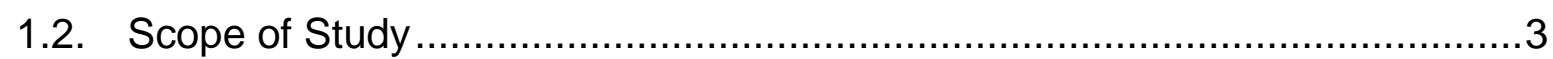

1.3. Objectives and Additional Research Questions ..................................4

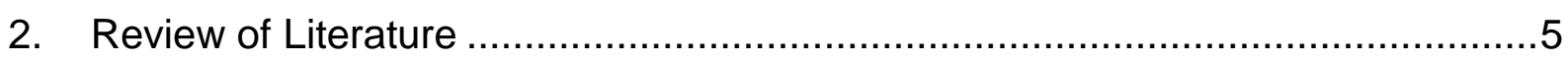

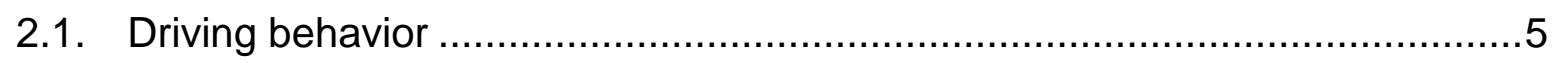

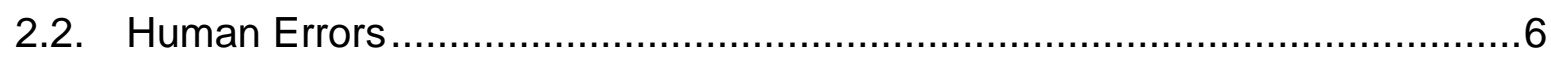

2.2.1. Types of Road, Weather and Traffic Conditions .............................

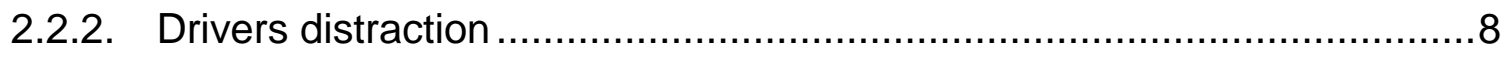

2.3. Mental Workload in the Driving Activity .......................................... 10

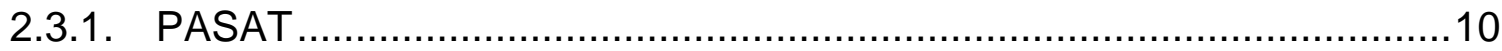

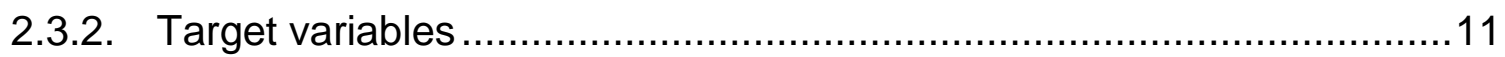

2.4. Driving Simulators in Workload Studies .......................................... 13

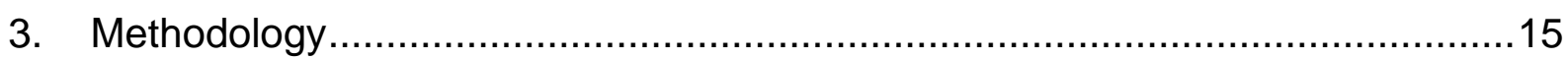

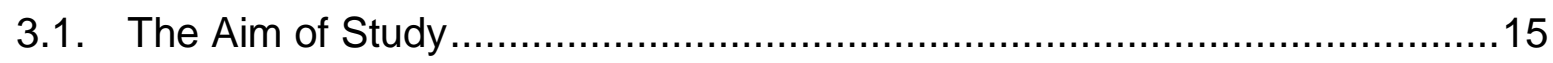

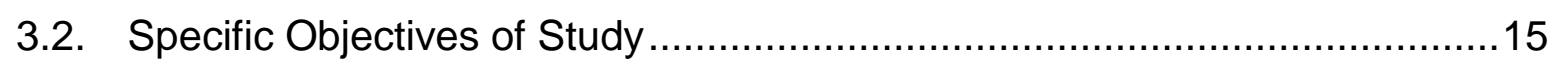

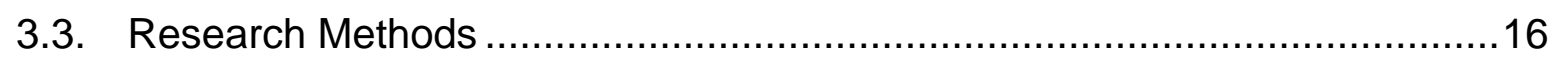

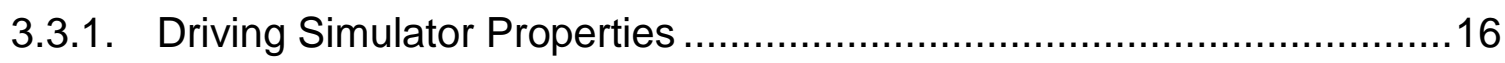

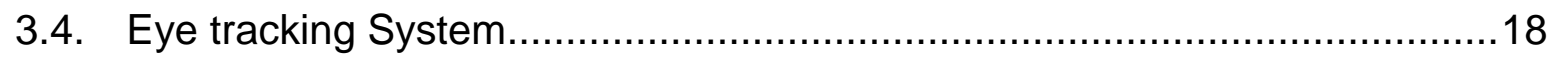

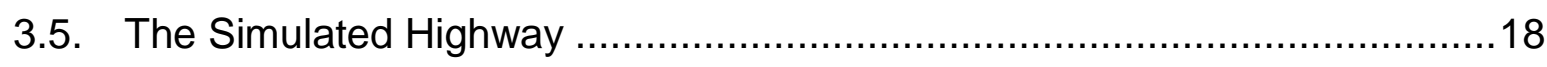

3.6. Determining the Chosen Curve ................................................... 19

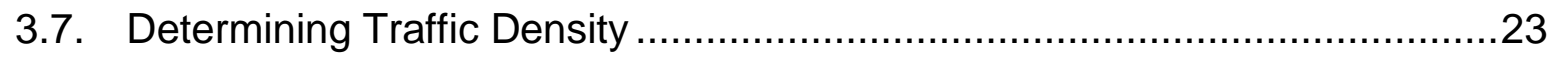




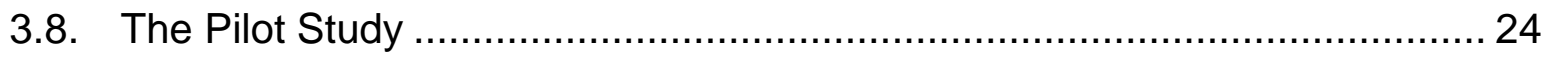

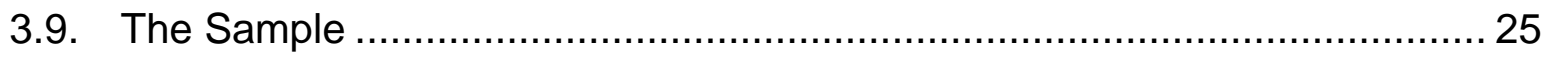

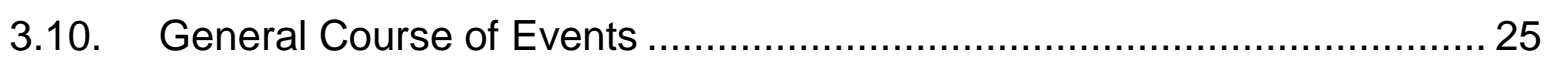

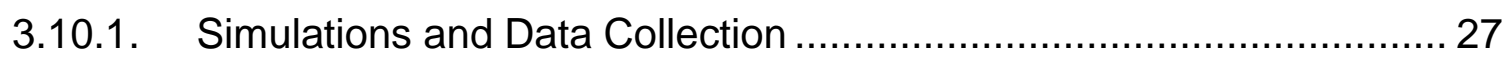

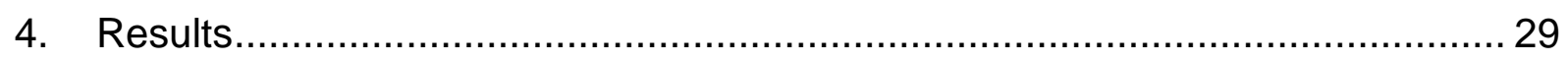

4.1. Average Speed According to the Road's Level of Service.......................... 29

4.2. Average Speed According to Curve's Level of Service............................... 33

4.3. Average speed according to mental workload ......................................... 36

4.3.1. Drivers' behavior with mental workload test ...................................... 39

4.4. Average speed according to the selection of the scenario .......................... 43

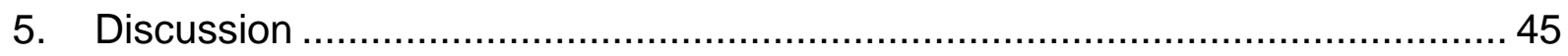

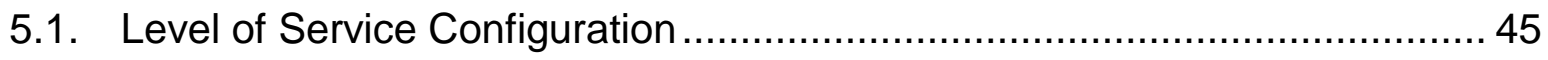

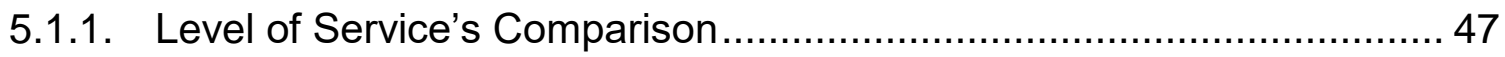

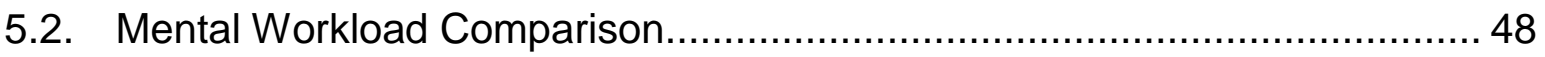

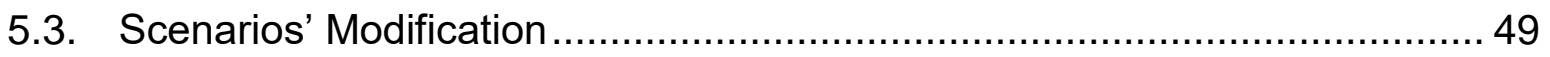

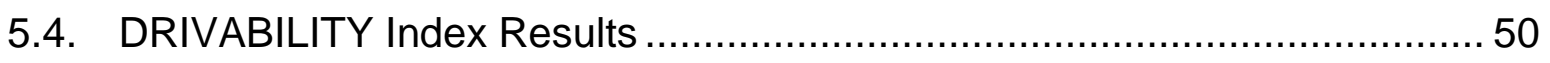

5.5. Presence Questionnaire ……………………..................................... 52

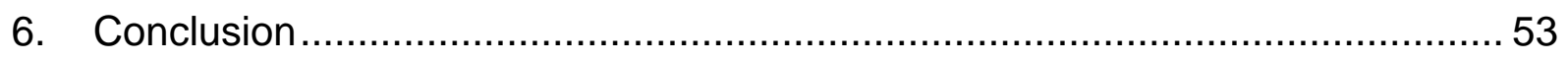

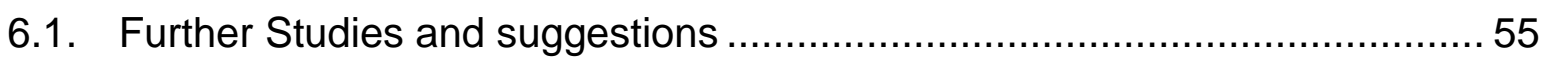

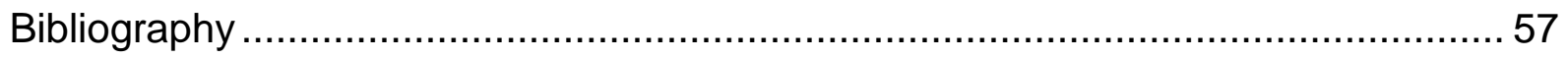

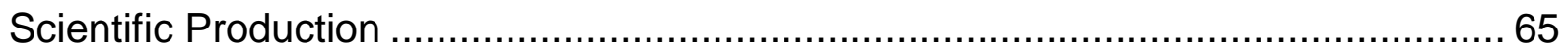

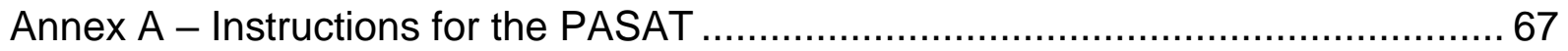

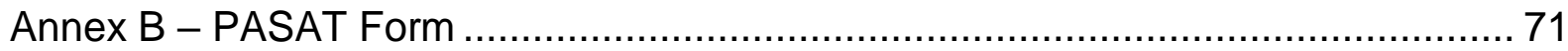

Annex C - Questionário de Caracterização do Condutor ......................................... 73

Annex D - Caracterização de Imersão no Simulador .............................................. 77 


\section{INTRODUCTION}

The aim of this research is to identify Brazilian drivers' behavior while performing driving tasks. Drivers' behavior was assessed by using driving simulations to compare their speed profile while driving around a curve. The virtual environment parameters were controlled in each simulation so that a comparative analysis could be performed in the selected variable. The main analysis was performed comparing the variation of speed profile of drives who were driving normally and when they were performing the same task under some distraction activities.

The driving simulator used in this research comprises a virtualized environment representing one of the main Brazilian highways. The driving simulator was set up on the premises of the São Carlos Engineering University, and consisted of an assembled cockpit-based steering wheel, gear shift and pedals. The virtual scenario was projected on a frontal projection screen $(1.80 \mathrm{~m} \times 1.10 \mathrm{~m})$ and includes sounds reproduction and wheel force feedback. The equipment's immersive perception is classified as a medium fidelity driving simulator in a scale from low to high fidelity (JAMSON, 2011).

This research was conducted in four stages as follows: 1) a pilot test to identify the level of mental distraction and select the curved section to be used in the study; 2) analysis of the vehicles' flow effect on drivers' behavior; 3) distraction-focused simulations and a survey conducted with participants; 4) analysis and validation of results.

The first stage was carried out to select distraction methods that could be used with drivers while they were driving. The main aim of the pilot test was to validate the use of distraction methods in the driving simulator. Eye tracking data was collected during the experiments in order to assess the variation in gaze time fixation due to distraction. 
The aim of the second stage was to identify the maximum level of traffic that would be suitable to generate an extra workload to drivers without changing their behavior. Participants drove on three identical virtual road stretches but with different traffic density levels. After storing the data, the simulations were categorized according to the flow of vehicles at the time of the curve, if it was a free-flowing or car-following situation (synchronous flow) and analyses were performed among these groups.

The third stage included the main experiment itself, i.e., the drivers' behavior and its variations on simulations performed with and without mental workload. The comparisons were determined using the speed profile obtained in the curve segment.

Lastly, results were compared to identify variations among drivers' behavior. Statistical analysis was performed on drivers speed values at points in the tangent ahead of the curve separated from each other by 50 meters, and some points located inside and after the curve. Factors capable of pointing out signaling variations and their influence on drivers' behavior were also identified.

Among the main findings of this research is the direct influence of distraction on driver failure in recognizing a dangerous curve. During the simulation under distraction, drivers failed to identify the beginning of a curve, and drove at high speed along this stretch. The main advantage of using a simulator in this type of experiment is the possibility of using virtual resources to measure behavior of drivers exposed to activities that could be highly risky if they were real driving situations.

\subsection{JUSTIFICATION}

Modelling human behavior is an extensively researched area which focuses on improving vehicle's safety systems and human performance (PANOU; BEKIARIS; PAPAKOSTOPOULOS, 2006). To identify factors that influence or initiate vehicle accidents, TREAT et al. (1956) reported that human errors account for $92.6 \%$ of these car crashes. The question which arises from this alarming statistic is why do humans make so many driving mistakes? The answer is that they do not. A driving task error does not mean that drivers took incorrect actions. It conversely means that they failed to perceive or process enough information to avoid crashing (GREEN, 
2003). Unfortunately, human errors such as those described in this example, can happen to anyone, and may not be eradicated. The possibility of identifying risky behavior and mitigate unsafe situations have been considered worldwide as a way to improve automotive safety (INAGAKI, 2007).

Modelling driver behavior meets this proposal, but the variety of behavior models is almost as numerous as the number of scientists researching it (CARSTEN, 2007). Due to the fact that driving includes numerous tasks and subtasks, and drivers are affected by personal reasons while driving, it is hard to identify and report solutions for every risk situation. However, it is possible to predict and anticipate behavior and situations that would allow improvements in driving laws and regulations, or contribute to improving in-vehicle information systems that would avoid situations where drivers were not paying attention.

Assessing drivers' behavior can be done by comparing drivers' speed profile in different situations. This is done by collecting the drivers' exact speed at different positions on the stretch of the road to build drivers' behavior through the segment (VÁRHELYI, 1998). Drivers' speed profiles on a road may be used to predict operating speeds for different conditions, such as horizontal or vertical curves, and it is not limited only to previously known parameters of road geometry (FITZPATRICK; COLLINS, 2000).

\subsection{SCOPE OF STUDY}

The scope of this research consisted of an initial investigation of drivers' behavior using a driving simulator. The aim of this investigation was to identify levels of comparative analysis that can be achieved with the simulator, particularly an initial comparison of drivers' behavior under distraction tasks. Furthermore, variety in density flows in simulated traffic, in the distraction level of participants and on road signaling could be achieved.

In this context, the scope is limited to comparisons among the selected variables, and does not include the behavioral characterization of the whole group of drivers besides the sample for the research. The drivers that participated in this study were 
sorted by convenience and drivers' personal characteristics related to age, driving skills and familiarization to the road were not taken into account to this selection, even though they contribute to drivers' behavior. Possible variations among drivers in this thesis shall be considered as exploratory research rather than concrete results.

\subsection{ObJectives and Additional Research Questions}

The main hypothesis investigated in this proposal is the measurement of variations on drivers' behavior according to the mental status of drivers: if fully focused on the driving task or distracted by any external source, such as a workload test.

Secondary hypotheses considered comparing the speed profile with variations in traffic density and road signs. These hypotheses helped to develop the main hypothesis and are complementary to the results of the first one.

Furthermore, driving performance can also be compared with distracted drivers' and aware driving. Performance in driving activity is a particularity of drivers' behavior where they try to achieve the best optimization of the situation.

Data concerning the driver's eye movements are extra information that may show the drivers' attention when driving, such as the perception of the scenario and the environment surrounding them while they were distracted or attentive. 


\section{REVIEW OF LITERATURE}

This section highlights the importance of road safety in our society, and how road safety is closely related to driver's behavior. A motorized society needs to be concerned about the enormous human cost of traffic crashes (EVANS, 1991). Although good road infrastructure improves users' safety, even on highways in excellent conditions, human factors can lead to accidents.

\subsection{DRIVING BEHAVIOR}

Drivers perceive their surrounding scenario and behave accordingly to their previous driving experiences. Drivers' actions in a given scenario are motivated by: (1) their concern about safety and (2) their urge to reach out the expected destination as soon as possible (CHAKROBORTY; AGRAWAL; VASISHTHA, 2004).

Driving is also considered as a hierarchical problem-solving task, with three different levels according to task requirements (MICHON, 1985). On top of the pyramid is the strategic level, which comprises all processes regarding trip decisions. Then, at the maneuvering level, all the mechanical decisions are taken as fast as necessary. Overtaking, turning and gap distance to the front vehicle are tasks that are taken according to drivers' motivations of safety and urge to reach the destination. These tasks are also taken obeying to what drivers decided at the first level. Lastly, the control level gathers all tasks related to stimulus response in order to do previous tasks in upper levels. For example, overtakes may demand a gear shifting or wheel steering correction to perform lane-keeping.

Another hierarchical modelling of drivers' behavior classifies human behavior into three levels, and ranks each level according to driving task (RASMUSSEN, 1986). In comparison with the Michon's model, the Rasmussen's model detailed the previous levels with basis on human skills, rules and levels of knowledge. The most recent 
driver behavior model moved from the hierarchical concept to a multi-dimensional sphere also based on human behavior. BEKIARIS, AMDISTIS \& PANOU (2003) developed a new concept for modelling of driver's behavior, namely, DRIVABILITY.

DRIVABILITY is an index that is calculated as a weight sum of the driving performance according to (1) individual performance: physical, social and mental status for each person; (2) knowledge/skills: not only driving task training and experience for each person, but also education level and social responsibility that may influence on the self-awareness of the drivers' skills; and (3) environmental factor: includes vehicle status, traffic hazards, weather and road conditions.

The main reason for modelling drivers' behavior is to identify gaps where drivers take unsafe actions or are exposed to risk situations. Identifying and predicting these situations are useful to mitigate the frequency of human errors in driving.

\subsection{Human ERrors}

Driver is the most critical and prone to failures component of traffic system. EVANS (1985) described the human behavior in the traffic system as a perverse phenomenon (safety changes in opposition to the expected sign) in a safety level scale from no safety change, safety change smaller than expected, safety change as expected, safety change higher than expected, and, finally, to a perverse effect. This means that driver's behavior is one of the key factors influencing the outcome of safety measures.

Human error is a "generic term that encompass all the occasions in which a planned sequence of mental or physical activities fails to achieve its intended outcome, and when these failures cannot be attributed to the intervention of some change agency" (REASON, 2000). This statement refers to road safety when drivers' intention to reach the destination is interrupted by failures, such as a car crash.

Not all failures result in accidents because there are high technology systems that insert defensive layers to protect likely victims and improve safety. Some of these layers include defenses, barriers and safeguards on the road's structure, and alarms, automatic shutdown and assistant driver on vehicles' systems. Even so, Human 
factors is one of the main causes of road crashes, if not the sole contributor (EVANS, 1985).

Studies on Drivers' behavior are intended to avoid or mitigate human errors. Sometimes, it is only caused by the lack of experience of drivers, but it can also be caused by a change in driving conditions not expected by the driver. Every portion of these changes affects the driver's behavior in a specific way, as listed in the topic below.

\subsubsection{TYPES OF ROAD, WEATHER AND TRAFFIC CONDITIONS}

Adverse weather conditions include rain/storms, flooding, snow, fog/smoke, extreme cold or heat, driving towards sunrise or sunset, etc. Drivers need to recognize these conditions that may impart a rather unique challenge to the task. Some of these challenges include reduced visibility, steering and traction ability, and increased time and space to stop the vehicle (DEPARTMENT OF TRANSPORT - ROAD SAFETY DIVISION OF SOUTH AFRICA, 2016). Extreme weather conditions require special skills from drivers to be safe on road, and such skills could be learned if only drivers are exposed to those conditions.

For this reason, the drivers' behavior model changes in severe weather conditions rather than in good weather. Drivers cited compensatory behaviors under extreme weather, for example, speed reduction (KILPELÄINEN; SUMMALA, 2007). Their behavior is not, however, a valid estimative of risk exposure as drivers not always adjust their behavior to the new expected conditions. For instance, drivers on slippery road (friction under 0.20) still drive at a speed slightly higher than the average road speed limit (HEINIJOKI, 1994 apud KILPELÄINEN; SUMMALA, 2007 p. 2).

Besides the overestimations on their own driving capabilities, drivers generally do not perceive changes of weather and road designs that require a change in the driving behavior (EDWARDS, 1999). When questioned about causes of crashes, bad weather, bad road design and traffic jam are three of the most concerned reasons (QUIMBY; DOWNING, 1991). Even though drivers recognize a dangerous situation, as the common examples aforementioned, they fail to avoid or prevent it. 
Traffic conditions reflect the level of service (LOS) of highways. LOS is assessed by parameters, including traffic density, speed, road structure, users' perception and quality of service (AASHTO, 2010). According to the three-phase traffic theory, the relationship between drivers and traffic is complex. Traffic movement is characterized by three indexes of efficiency: flow, density and speed. Figure 1 represents the moment when traffic flow moves from a free flow situation to a car following scheme. Drivers must adapt quickly to this movement, as a new driving ability is required under new conditions (COOPER et al., 2009).

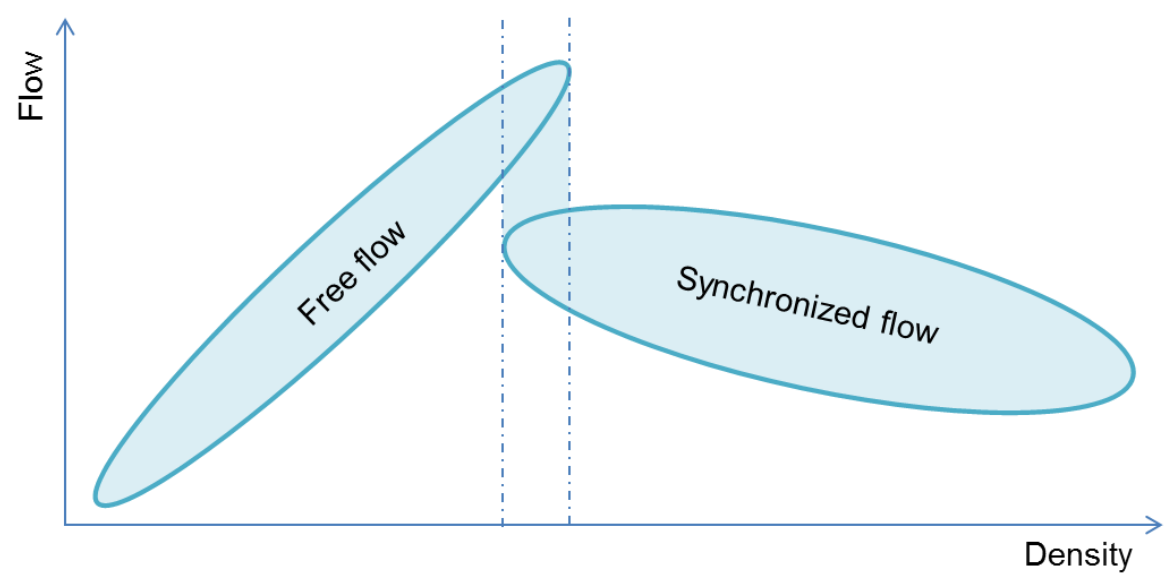

Figure 1. Flow versus density graph. The shaded zone represents the moment when drivers change from a free flow situation to a car following synchronized flow (Adapted from KERNER, 2012)

\subsubsection{DRIVERS DISTRACTION}

Distraction implies lack of attention to a relevant goal. It involves discussing how we should pay attention, how information should be acquired, how information should be processed, and how an action should be taken (RECARTE; NUNES, 2009). A distracted decision while driving may lead to errors, but it may also be a successful task, as it commonly happens. Undemanding and monotonous conditions bring drivers to a fatigue status, which is succeeded by distraction.

Based on a wide range records of drivers' behavior in naturalistic studies, distraction contributed for $78 \%$ of crashes and $65 \%$ of near-crashes (KLAUER S. G., DINGUS T. A., NEALE V. L., SUDWEEKS J., 2006). Further research was conducted with focus on teenager drivers, correlating the three main types of crash with four driving 
distractions categories (NEYENS; BOYLE, 2007). The authors observed that the higher the distraction level the greater the number of accidents and risky situations.

The equation to categorize distraction is described by the total attention of driver minus the workload required by the driving task. Despite the simplicity of this estimation, significant effort has been made to measure the mental workload. How to measure attention? How to detect required workload? We can find examples of useful models to quantify mental workload, as for example, in the assessment of information-processing errors made by operators in the air traffic control (WICKENS, 1984 apud RECARTE; NUNES, 2009: 83), and in the drivers performance (WAARD, D DE; BROOKHUIS, 1997).

The expected relationship between performance and workload is illustrated in Figure 2. Performance represents the driver's ability to develop a task, and demand is related to the driver's attention less distraction. A task performed perfectly requires less attention than one poorly achieved. This means that driving throughout a curve requires more attention than driving in a tangent path.

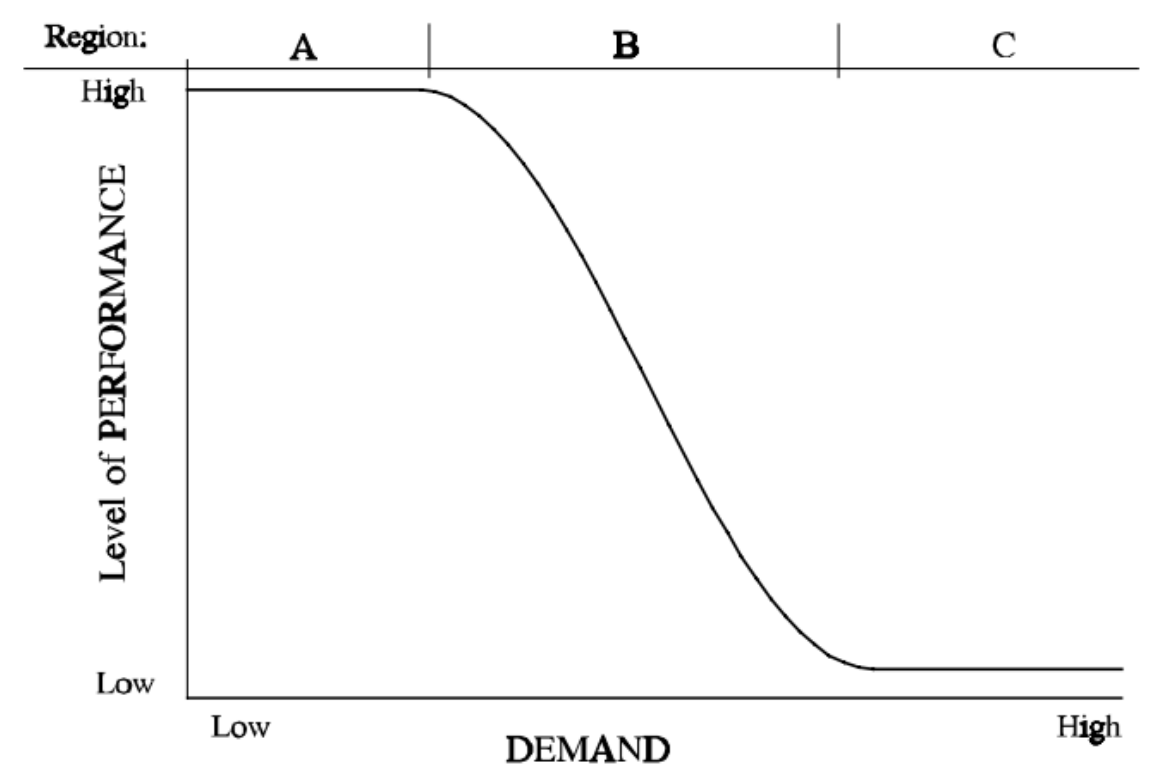

Figure 2. Relationship between demand and performance (MEISTER, 1976)

Mental workload is subtracted from demand. It implies that attention is a critical feature for highly demanded situations. Despite the complexity of the driving activity, the required workload is sufficiently low at most of time so that the drivers can perform secondary tasks, for example, to speak at the mobile. Nevertheless, the 
surrounding environment workload demand can exceed the driver's capacity rapidly, thus resulting in an car crash (CRUNDALL et al., 2003; PRADHAN et al., 2013).

\subsection{Mental Workload in the Driving Activity}

A simple definition of workload is a placed demand that requires some immediate action. More specifically, workload is the amount of information-processing capacity that is needed to perform a task.

Mental workload is commonly assessed by classifying driving activity into primary and secondary tasks. Primary task is related to driving activity itself, while secondary task is related to distraction caused by external factors. PARKES (1991) defines primary task as the "safe control of a vehicle within the traffic environment". Some activities are not easily defined according to this classification as well as workload is not easily split for each task (DE WAARD, DICK, 1996). Sources of mental workload may be found inside or outside the vehicle in a complex junction.

This thesis is focused on investigating how extra mental workload influences drivers' behavior in a highly demanded situation. Because the drivers speed profile is collected in a curve (low performance in a highly demanded situation), any worsening of performance, in comparison with the normal workload demand, would be probably due to the extra workload. The workload used by drivers to correct the curve trajectory in order to improve performance is classified as a primary task, but workload inserted simultaneously to produce distraction is a secondary task. Thus, mental workload as secondary tasks is applied on drivers to produce distraction. The level of distraction is acquired from PASAT, which is described in the topic below.

\subsubsection{PASAT}

An adaptation of PSAT (Paced Serial Addition Task) where applied to produce drivers' distraction. This test was originally designed to measure mental rehabilitation of patients who suffered accidental trauma at brain, which further led to amnesia or coma diagnosis (GRONWALL, 1977; SAMPSON, 1956). 
The adaptive test, named PASAT (Paced Auditory Serial Addition Task) test was developed to distract drivers from primary task, but keeping original instructions and specifications. Currently, PASAT is one of the most common tests used to produce distraction (Annex B - PASAT Form contains instructions about the PASAT procedure). Further adaptations are implemented to create a more precise workload test according to the objectives. For instance, ROYAN et al. (2004) reported a Adjusting-PSAT test, in which the test speed varies depending on the participant's ability to perform the test.

A modified PASAT approach that has been tested in previous simulation researches was applied in this thesis. Its effectiveness confirmed the loss of cognitive ability of the drivers while using mobile phones. LAMBE et al. (1999) investigated the driver's behavior in car following situation and compared the results with PASAT task application. In both cases, the safe distance to the vehicle ahead was kept under safety margins, and consequently there was a decrease in risk perception. A similar investigation evaluating drivers' eye fixation while in a tangent stretch of a rural highway found a loss of ability of drivers to identify the beginning and the end of a curve ahead while answering PASAT task (LEHTONEN; LAPPI; SUMMALA, 2012).

PASAT also revealed the need of enhancing the driving skills of multiple sclerosis patients (KOTTERBA et al., 2003). The same research also identified a significant relationship between cognitive decline caused by physical impairment and rate of accidents. The cognitive decline was also found in subtasks of driving activities (LEl; WELKE; ROETTING, 2009). The performance measurement of cognitive decline was also provided by electroencephalography (EEG) analysis.

\subsubsection{TARGET VARIABLES}

Comparing drivers' behavior according to any target variable is a complex attempt to establish the relationship between driver and traffic system, which is usually constituted of a dynamic interaction (PANOU; BEKIARIS; PAPAKOSTOPOULOS, 2006). 
Workload can be assessed by different methods and can be divided into three main categories (DE WAARD, DICK, 1996):

- Self-report measures: based on questionnaires and scales applied after completion of the task. Users can answer about their self-impression of the overall workload task or their effort to realize it.

- Performance measures: primary and secondly-task performance measures have to be carefully selected to properly assess the workload and remove the user's impression about the activity. Time to complete the task and average or punctual speed can reflect changes in goal settings, while steering-wheel measures can be applied on a known curvature spot of the road. Secondarytasks are related to the driver's experience in driving, such as frequency of mirror-checking and car-following performance.

- Physiological measures: measurement of physiological signals by expertise and specialized equipment. For example, heart rate measure can identify a stress situation during the recent task. To avoid different preconditions among participants, a combination of before and after-task measurements is desired.

In order to assess the additional cognitive load by in-vehicle information systems, the visual occlusion technique is added as an additional category (GELAU; KREMS, 2004). Driving is a visual task, hence if the drivers cannot see, they cannot drive. In this sense, researches intended to determine how often drivers need to look to provide a basis for driving, and presumably any time in excesses of this limits is available for other purposes or redundant information (TSIMHOMI; GREEN, 2001; VAN DER HORST, 2004).

Also, drivers' mental workload is more than just the task's workload. Emotional information and physiological factors, such as monotony and driver's sleepiness, have an important effect on mental workload (MEIJMAN, 1991). Moreover, when traffic research is performed, another set of variables and conditions are included and may be considered (KANTOWITZ, B H, 1992).

HICKS \& WIERWILLE (1979) compared the sensitivity of five methods of mental workload in terms of changes in operator workload: primary and secondary task 
performance, visual occlusion, cardiac arrhythmia and opinion rating scales. The primary task consisted in driving an automobile simulator and the results described relationships between workload and lateral deviation, yaw deviation, and steering reversals.

Physiological measures were not applied in the studies described in this thesis. However, an overall understanding of driving requirement is necessary to assess drivers' behavior facing a secondary task while driving, as well as the influence of this secondary task on the performance of the participants. A secondary task is a task that is not required for safe driving (JOHNSON; PROCTOR, 2004; PEW, 1979).

\subsection{Driving Simulators in Workload Studies}

"Driving simulation was originally developed to avoid the cost of field studies, achieve more control over circumstances and measurements, and safely present hazardous conditions" (ALLEN; ROSENTHAL, T.; COOK, 2011). The main reason to use driving simulators in workload studies is due to subjectivity of the driving activity and the difficulty to assess workload.

Controllability in an experimental environment under controlled conditions and prerequisites are critical in workload studies. The replication of identical scenarios and conditions for each participant allows comparing drivers' performance acceptably (KANTOWITZ, BARRY H., 2011). It is easy to program workload and distraction in driving simulators. Although secondary tasks that produce distraction are not a characteristic of simulators, the control of the first-task environment simplifies comparative analyses (KANTOWITZ, BARRY H; SIMSEK, 2001). Careful use of main tasks is required in order to detect changes of behavior. It is impossible to develop workload studies in real world due to the excessive care of experiment replication.

Drivers can freely perform their driving abilities as long as they obey regulations and federal laws imposed to driving activity. Despite freedom, education has an considerable influence on the society behavior in traffic (KANTOWITZ, BARRY $\mathrm{H}$., 2011). Using driving simulator for this purpose is fast and accurate, due to the total 
control of simulated environment. Experiments conducted in driving simulators worldwide have helped policies for regulation and implementation of road speed management (GHADIRI et al., 2013).

Studying driver's behavior under demanding conditions implies dangerous situations that exclude experiments with distraction in real life. The investigation of actions or lack of actions preceding critical situations under mental workload can be safety conducted on simulators.

Despite some limitations in simulation, such as lack of realism and absence of motion (GOODMANN et al., 1999), driving simulators still achieve psychological reliability in the participants when simulation experience meets the realistic expectation. 


\section{Methodology}

\subsection{THE Aim OF STUdY}

The study conducted in this proposal aimed to compare drivers' behavior while driving along a rural highway's curve under distraction and full attention conditions. The main variable adopted was driver's speed profile, punctually collected along the selected curve, and on tangent stretches located directly before and after it. Other variables were considered to compare behavior, such as driver's ability to control the vehicle, lane position and eye tracking data. Besides the main goal, the comparison was also conducted under other aspects on a simulated vehicle, such as variable density of traffic and scenarios with different road signs.

All the variables were collected in a virtual environment and modifications were controlled through simulation's software and repeated identically to all participants from sample.

\subsection{Specific ObJectives OF Study}

In order to comprehend drivers' behavior and validate their models in driving simulators, this study evaluated driver's speed profile at a selected curve given determined points:

- 200 meters, $150 \mathrm{~m}, 100 \mathrm{~m}$ and $50 \mathrm{~m}$ ahead of the curve

- The beginning, middle point and end site of the curve

- $50 \mathrm{~m}$ after the end of the curve.

The sites chosen to collect data corresponded to begin, end, and midpoints of curve (BIRD; HASHIM, 2005) and spaces of 50 meters on tangents (BROWN, 1999). The four points in advance of the curve aimed to analyze drivers' behavior while they 
were approaching the curve path. These points may be collected in a tangent situation, never if in there were located in a previous curve. The points gathered among the curve measured the inflection point found by drivers when they sought the beginning and the end of the curve. The point after the end of the curve was gathered to compare the behavior when drivers sought the end of the curve and when they actually left it.

The comparisons were held under three aspects, considering the points collected above:

- Variations in the level of service through changes in traffic density: to define the level of traffic parameters for the main goal of the proposal.

- Application of distraction to drivers: using a mental workload test as the main analysis of the thesis.

- Variations in simulated scenarios: changing signs and curve's demarcations as a further study possibility.

\subsection{Research Methods}

\subsubsection{DRIVING SimUlator PROPERTIES}

The driving simulator employed at this proposal was a microworld environment. Microworld are computer-generated environments, operated in real-time and controlled by operator (BREHMER; DîRNER, 1993). The physical structure of the simulator was composed of a driving cockpit with car seat, steering wheel with paddle shift and force feedback and accelerator, brake and clutch pedals (Figure 3). The cockpit station also allows adjustments of distance in height and between the seat and steering wheel.

The simulated environment was projected in a $1.40 \times 0.80 \mathrm{~m}$ flat panel with $1080 \mathrm{p}$ resolution and $60 \mathrm{~Hz}$ projection rate. The projected field of view was $120^{\circ}$ on horizontal vision and $50^{\circ}$ on vertical. Rear and lateral mirrors and speedometer are also projected on panel. To improve immersion, speakers reproduced sounds like vehicle engine, rain and wind. 


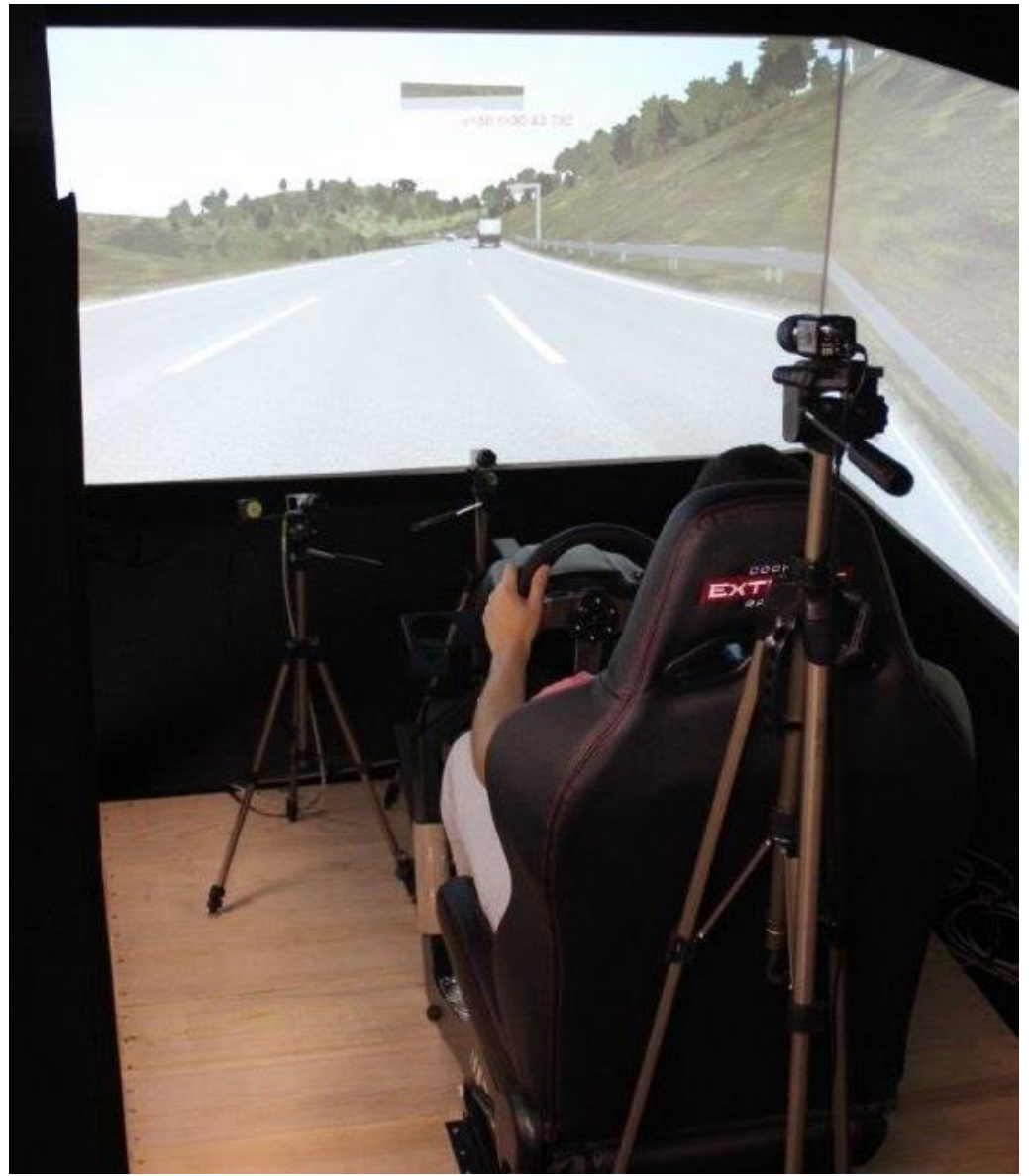

Figure 3. llustration of simulator's cockpit and projection screens. Additionally, 4 eye tracking camera systems captures eye movements.

Three desktops computed real-time simulation. The first one, responsible for environment rendering and simulation running, was strengthened with two GPUs. The second computer modeled vehicle dynamics. This dynamics included interaction road - vehicle and the mechanical answer to operators' actions. Vehicle's dynamics was similar to a Brazilian ordinary vehicle version. The third computer was employed to collect eye tracking data, described on the subchapter below.

These simulator characteristics allowed participants to feel a medium fidelity immersion, with visual and auditory stimuli similar to real driving experience. It was achieved due to high computational capacity that modeled and rendered virtual environment in real-time processing. However, the immersion was limited by three factors, highlighted on results' comparison between real and simulated driving experience. The lack of a motion platform excludes the sensation of force dynamics 
and vibrations produced by track contact with tires; wheel steering and engines operation and usage of a cockpit instead of a passenger compartment also included a lack of immersion perception.

\subsection{EYE TRACKING SYSTEM}

As an assistant variable to track driver's behavior, an eye tracking system was integrated to driving simulator. This system is based on corneal reflexing images. Eye tracking is computed according to the position of an infrared red light reflected on cornea. Three cameras placed in front of user collect reflection at a $60 \mathrm{~Hz}$ rate and assess eye movement in real time. This eye tracking technique is mostly used nowadays for being noninvasive. Other invasive method include electrodes and contact lenses with inductive sensors (YOUNG; SHEENA, 1975). Also, it's a nonwearable system, once the user isn't directly connected to the accessory (like wearing glasses). It also increases comfort and become imperceptible to participant (DUCHOWSKI, 2007).

As infrared and cameras positions were previously known, an estimation of head position can be calculated, as well as eye movement. To determine cornea reflection, a system calibration before simulation increases accuracy and precision. Tracked data is collected by a forth camera that stores user's view.

\subsection{The Simulated Highway}

The rural road used for the development of this master thesis is a main road in Brazil with high traffic connecting São Paulo state to Paraná, in a ten kilometers stretch

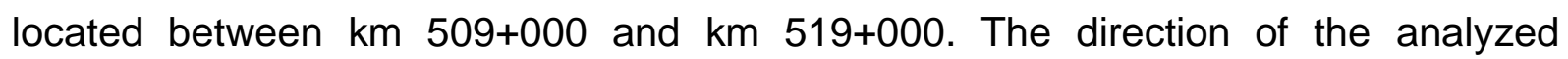
highway is from São Paulo to Curitiba. This section is located in the municipality of Cajati, in a mountainous region named Serra do Azeite.

This road is a 4,513 km long highway. It extends from Ceará state (Northeastern Brazil) to Rio Grande do Sul state, on the southern border with Uruguay. The highway runs through 9 of the 10 most populated states in Brazil. The stretch between the city of São Paulo and Curitiba is named Autopista Régis Bittencourt and 
has $402.6 \mathrm{~km}$ long. It's a duplicated stretch in $92 \%$ of its length. The road is part of the main corridor connecting southern and southeastern Brazilians important economy centers, and these regions with Mercosur countries (AUTOPISTA REGIS BITTENCOURT, 2013).

The highway administrator provided the geometric design of the stretch under study, necessary for the virtual modeling for simulation, as well as the AADT and extra data gathered at the toll stations close to the stretch. The location, type and severity of accidents on the road in recent years have also been provided.

According to its geometric design, the section was subdivided into 20 curves and 19 tangents. The selection of the studied curve was based on its length and curvature, as well as the length of the tangent prior to the curve. It's a $200 \mathrm{~m}$ length curve with $130 \mathrm{~m}$ curvature radius, a very short curvature radius that should measure at least $230 \mathrm{~m}$ for a rural highway Class 1-A, with $80 \mathrm{~km} / \mathrm{h}$ speed guideline (DNER, 1990).

\subsection{Determining the Chosen Curve}

The length of the curve and its previous and afterward tangent were crucial to select the curve on which driver's behavior could be explored. A very short length stretch in any of these segments would increase outliers' occurrence due to low time of collected data. To run across $100 \mathrm{~m}$ along a highway, drivers at $120 \mathrm{~km} / \mathrm{h}$ take around 3 seconds. Short time to perform the curve and subjacent tangents won't be precise to determine speed profile in this section. For this reason, it was determined that the length of tangents and the curve should be long enough so that drivers stays at least twenty seconds on the segment: at least ten seconds on tangents and ten seconds to perform curve. For the estimation, it's considered the highway's current speed limit of $60 \mathrm{~km} / \mathrm{h}$.

However, to select a stretch that requires a high mental workload from participants, the selected curve was chosen after a lookout at car crash statistics on the road in the last 3 years, from 2013 to 2015. Figure 4 presents this statistics and car crashes were classified for each curve. Accidents that happened after the beginning of a curve or in the tangent ahead was categorized as belonging to that curve, as the crash started during or after it for any reason. Also, it was supposed that these 
accidents may have some influence from drivers' inability to concentrate on the driving task.

Table 1 presents the reason of accident reported by drivers to police officers after car crashes or situation observed by police officer in the place of accident. Among the 10 most common answers given, more than $68 \%$ of them may be considered as drivers' inattention to the task. This category also composes the top 4 answers of table.

Table 1. Drivers' answer about the reason of accidents

\begin{tabular}{lr}
\hline \multicolumn{1}{c}{ Reason of accident } & Total of answers (\%) \\
\hline Losing control (inability) & $28 \%$ \\
Excessive speed & $18 \%$ \\
Driver's negligence & $11 \%$ \\
Slept while driving & $10 \%$ \\
Unexpected block & $9 \%$ \\
Rain & $4 \%$ \\
No answer & $2 \%$ \\
Mechanical/Electrical problem & $2 \%$ \\
Skidding & $2 \%$ \\
Cargo heeling & $2 \%$ \\
\hline
\end{tabular}

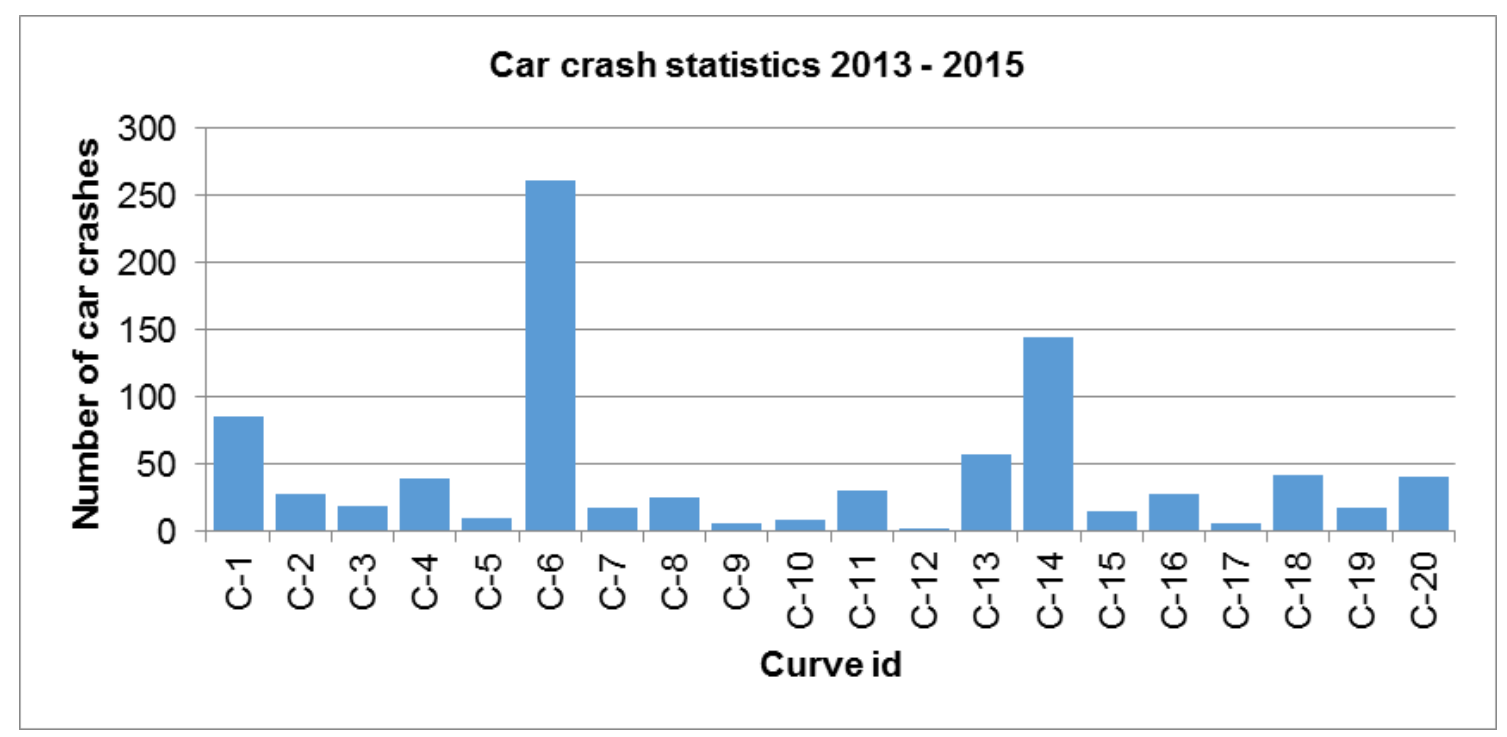

Figure 4. Car crash statistics identified by curves 
Curves with the highest accident rate were C-6, C-14 and C-1 (Figure 4). Just these three curves were responsible for $56 \%$ of all accidents in the stretch for the last three years. Considering the minimum time to perform tangents and the curve, the minimum length of tangents must be $83 \mathrm{~m}$, and $166 \mathrm{~m}$ to the curve stretch. Also, it was preferred to select a sharp curve, with a curve radius inferior to the $230 \mathrm{~m}$ as defined in the guidelines specification. Table 2 presents the total of accidents for each of these segments, as well as the length of tangents and curve, and the curve radius. In light grey are highlighted the most danger curves, and bold numbers are those itens that didn't fulfilled the requirements to this proposition.

The curves without any restriction were: C5 with a total length of $751 \mathrm{~m}, \mathrm{C} 14$ with a total length of $960 \mathrm{~m}, \mathrm{C} 15$ with a total length of $670 \mathrm{~m}$ and C16 with a length of 833 $\mathrm{m}$. The longest and most dangerous curve to support this selection was $\mathrm{C} 14$, which were used in further analysis on this proposal for comparisons on drivers' behavior. Figure 5 and Figure 6 present project configuration of the segment and aerial view of the selected curve's geometry with yellow points determining points of speed detection.

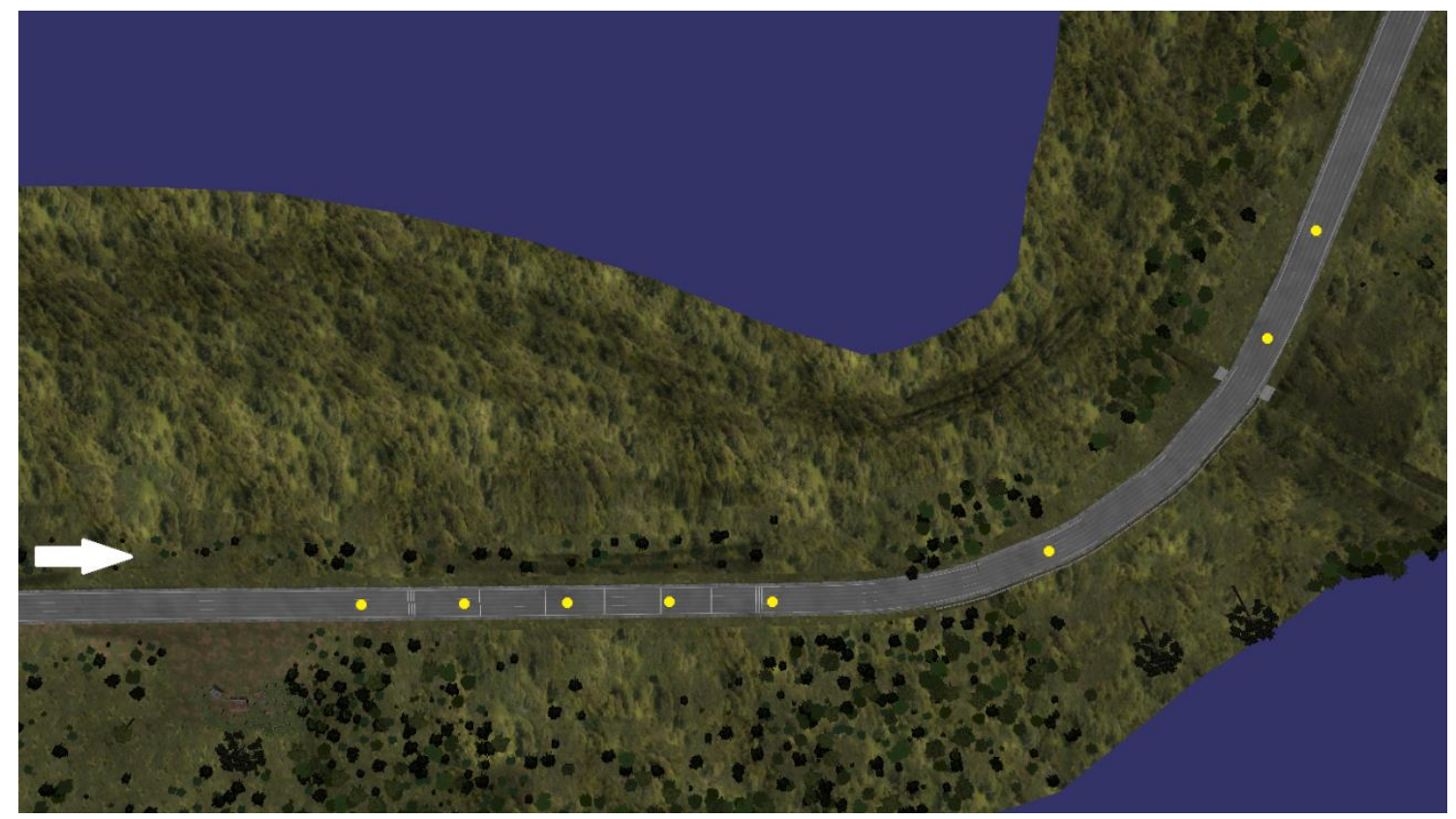

Figure 5. Aerial view of simulated C-14 geometry 


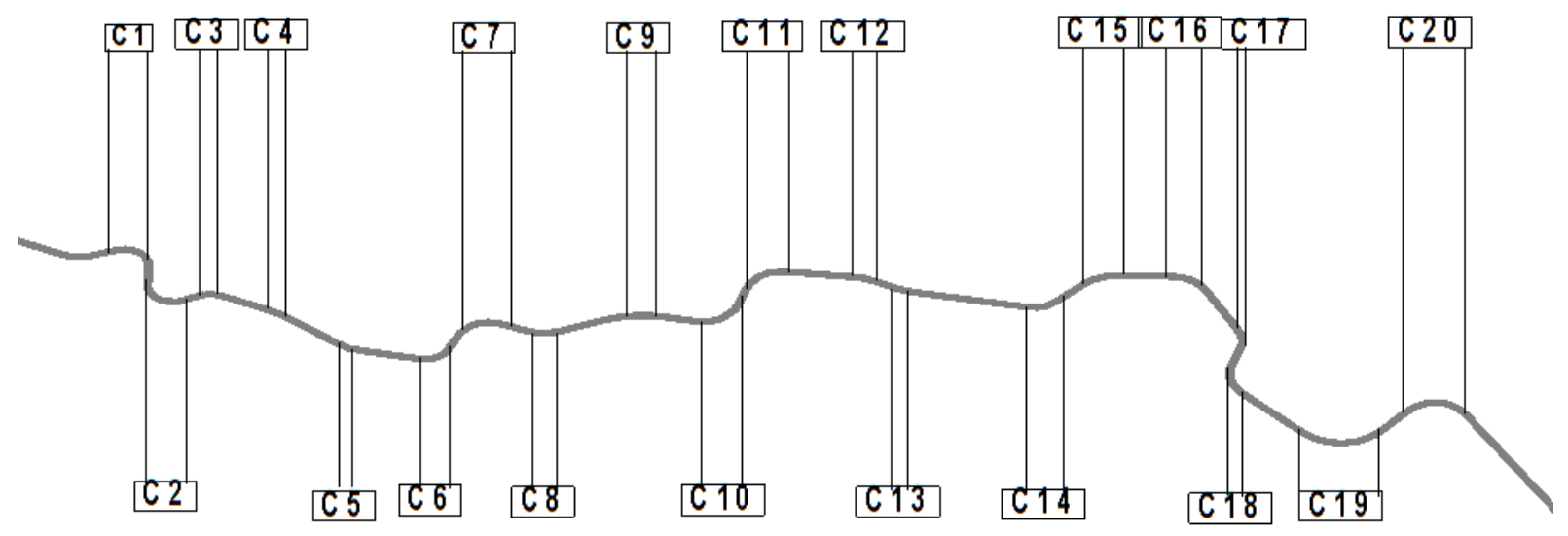

Figure 6. Stretch's profile and curve's identification (C14)

Table 2. Length of stretches, total of accidents and radius for each curve on segment

\begin{tabular}{ccccccc}
\hline ID & $\begin{array}{c}\text { Start Point } \\
(\mathbf{K M})\end{array}$ & $\begin{array}{c}\text { Total of } \\
\text { accidents }\end{array}$ & $\begin{array}{c}\text { Previous tangent } \\
\text { length }(\mathbf{m})\end{array}$ & $\begin{array}{c}\text { Curve } \\
\text { length }(\mathbf{m})\end{array}$ & $\begin{array}{c}\text { Afterward tangent } \\
\text { length }(\mathbf{m})\end{array}$ & $\begin{array}{c}\text { Curve } \\
\text { radius }(\mathbf{m})\end{array}$ \\
\hline C1 & $508+740$ & $10 \%$ & 100 & 347 & $\mathbf{6 5}$ & 130 \\
C2 & $509+175$ & $3 \%$ & $\mathbf{6 5}$ & 338 & $\mathbf{4 0}$ & 130 \\
C3 & $509+550$ & $2 \%$ & $\mathbf{4 0}$ & 174 & 235 & 130 \\
C4 & $509+960$ & $4 \%$ & 235 & $\mathbf{1 4 2}$ & 310 & $\mathbf{6 1 5}$ \\
C5 & $510+435$ & $1 \%$ & 310 & 166 & 275 & 190 \\
C6 & $510+875$ & $30 \%$ & 275 & 261 & 50 & 130 \\
C7 & $511+170$ & $2 \%$ & $\mathbf{5 0}$ & 341 & 65 & 180 \\
C8 & $511+575$ & $3 \%$ & $\mathbf{6 5}$ & 263 & 245 & 230 \\
C9 & $512+080$ & $1 \%$ & 245 & 345 & 115 & $\mathbf{6 1 5}$ \\
C10 & $512+540$ & $1 \%$ & 115 & 369 & 50 & 190 \\
C11 & $512+960$ & $3 \%$ & $\mathbf{5 0}$ & 352 & 300 & 190 \\
C12 & $513+645$ & $0 \%$ & 300 & $\mathbf{1 6 2}$ & $\mathbf{5 0}$ & 230 \\
C13 & $513+860$ & $6 \%$ & $\mathbf{5 0}$ & 170 & 570 & $\mathbf{6 0 5}$ \\
C14 & $514+640$ & $16 \%$ & 570 & 205 & 185 & 130 \\
C15 & $515+030$ & $2 \%$ & 185 & 270 & 215 & 230 \\
C16 & $515+515$ & $3 \%$ & 215 & 288 & 330 & 190 \\
C17 & $516+135$ & $1 \%$ & 330 & 217 & 45 & 155 \\
C18 & $516+395$ & $5 \%$ & 45 & 342 & 395 & 215 \\
C19 & $517+130$ & $2 \%$ & 395 & 564 & 168 & $\mathbf{2 8 5}$ \\
C20 & $517+825$ & $5 \%$ & 168 & 424 & 90 & 185 \\
\hline
\end{tabular}




\subsection{Determining Traffic Density}

The traffic density to distraction simulations was estimated on data collected at toll stations (CASTILLO, 2015). Parameters to compose traffic quality include number of lanes, road's slope, and percentage of heavy vehicles. Average annual daily traffic (AADT) considered for estimation were 872 vehicles/hours. It was composed of $32 \%$ passenger vehicles, $63 \%$ heavy vehicles and $1 \%$ motorcycles.

To compose different level of services to traffic density simulation, equations from AASHTO's (2010) Highway Safety Manual were applied to these three situations. Table 3 presents mainly variations from each level of servicing considering subjective parameters available to drivers experience. To compose traffic variation it was assessed simulations in LOS A, C and E levels of service and Figure 7 an example of traffic in each of these levels.

Table 3. Comparison of level of services according to flow, speed and comfort (adapted from AASHTO, 2010)

\begin{tabular}{cccc}
\hline Level of service & Flow & Speed mobility & Psychological comfort \\
\hline A & Free flow & Complete mobility & High level \\
B & $\begin{array}{r}\text { Reasonably free } \\
\text { flow }\end{array}$ & Speed maintained & High level \\
C & $\begin{array}{r}\text { Near or similar to } \\
\text { free flow }\end{array}$ & Speed maintained & Mostly comfortable \\
D & Synchronous flow & Slightly decrease & Comfort decreases \\
E & Synchronous flow & Speed varies rapidly & Poor comfort \\
& Traffic jam & Slow speed & Lack of comfort \\
& & &
\end{tabular}




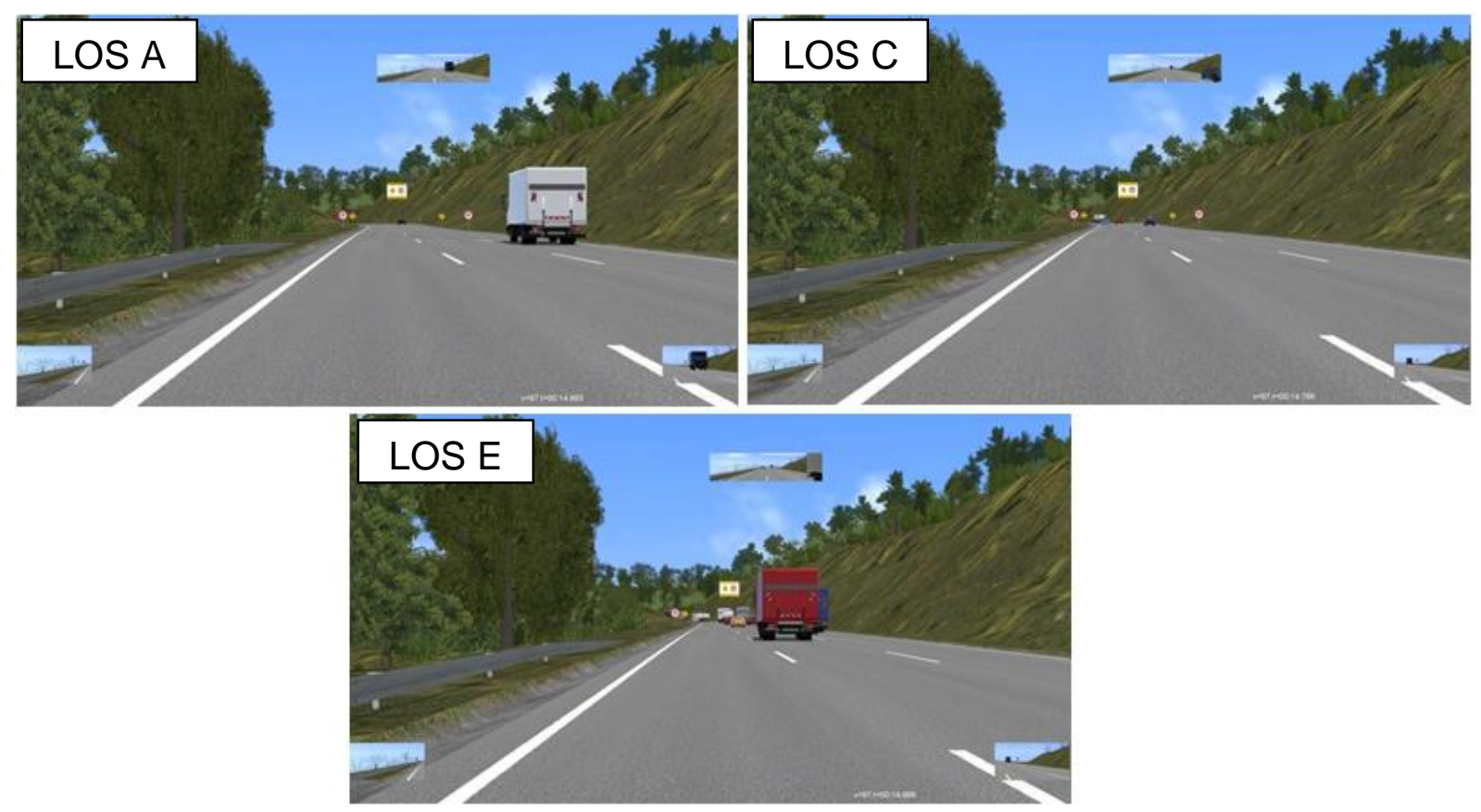

Figure 7. Example of traffic in the three different levels of service

\section{8. $\quad$ The Pilot Study}

A previous study collecting driver's data under the influence of PASAT compared variation of driver's field of view. A 3" PASAT were applied in a limited stretch of simulation, and eye fixation time compared with data from the same driver in another exactly simulation (SARTORI et al., 2015). 16 University's students and employees took part in this study. Analysis couldn't infer discrepant variation in eye fixations time, but a change in driving behavior was found among drivers. While answering the test, participants were keeping their trajectory straight, and not looking for overtaking opportunities or reducing their average speed.

This proposal was molded considering those observations. At first, PASAT was extended from 3 to 5 minutes, including a faster and demanding version. Also, analysis was applied in a unique curve to reduce complexity produced in a scenario with several variables. 


\subsection{THE SAMPLE}

The overall sample consisted of 38 participants (24 males and 14 females) aged between 18 and 31 years old ( $\mathrm{M}=22.5, \mathrm{SE}=1.9$ years). All participants had held a valid driving license for 1 to 10 years $(M=3.7, S E=2.2$ years $)$ and signed a consent term to perform the mental load test.

This proposal's scope doesn't included characterizing driver's behavior of any specific group or population, but to identify a behavior tendency and to validate simulators usage on this kind of research. Under this condition, the sample was defined for convenience. Recruitment was held on Facebook's groups of USP and UFSCAR Universities attracting applicants to try out driving simulator. They answered an online form to check if requirements of holding a driving license and minimum driving experience were fulfilled. The next step was to schedule a free time for simulation.

From participants that took part in distraction test (group one), eight of them were classified themselves as experienced drivers and nine as inexperienced. Among the inexperienced, two of them never drove regularly, despite of holding a driving license. Considering experience in rural roads, three of them never drove on a highway similar to the simulated scenario, six participants drove in this kind of highway at least once a year and eight drivers regularly drove under these conditions. For the selfassessment of driving behavior, ten participants classified themselves as careful, six of them as confident and one as insecure.

\subsection{General Course of Events}

Data were collected for each participant at a time through three types of sources: personal forms, with information provided spontaneously by participants, computed data and a video recording of simulations.

At first participants answered demographics characteristics forms (Annex C Questionário de Caracterização do Condutor). It consists of a consent term for PASAT and information about previous experience of participants in driving simulators similar to the one used in this research. 
Each participant was selected for a different type of collected data. Participants applying for the first week were conducted to group 2 simulations and participants on the second week performed group 1 simulations. Each group isolated a unique variable for comparison. Participants in group 1 took part in workload distraction simulation, performing two identical simulations, once with workload and another one without this task. The second group performed three simulations varying the levels of service of traffic around drivers. Levels of service A, C or E determine an increasing quantity of vehicles on the road, from a free flow to a high density situation. Variables are presented on Table 4, including a comparison among groups 1 and 2. The scenario for each presented group was exactly the same in geometry and traffic, but with improved signs position, including a bigger curve sign to identify the selected curve for group 2 participants.

Before starting simulations, participants were instructed of procedures and mechanical operations. At first they drove on a sample road until they find themselves familiarized with device and feeling comfortable with the simulation. The adaptation simulation lasted for 5 minutes for each participant. After the end of the experiment, they filled a last form (Annex D - Caracterização de Imersão no Simulador) giving their opinion about simulator's immersion. This test assessed driving simulators in six categories: realism, actions in virtual environment, interface, self-performance, possibility to explore virtual location and sounds.

Immersion is closely related to the effectiveness of virtual environment, linked to the sense of presence reported by users in these locations (WITMER; SINGER, 1998). Presence is classified as an experience of being in a determined place, whether a local or virtual place. Although presence varies across a wide range of factors and is a subjective or mental manifestation (SHERIDAN, 1992), individual position can be standardized employing a measurement scale for answers. A seven degree scale, with opposed answers on extremities and an average option in the middle only, cover subjective range of answers and validate immersion assess. 
Table 4. Variables identifications for groups 1 and 2

\begin{tabular}{cccccc}
\hline & \multicolumn{2}{c}{ Previous Scenario } & & \multicolumn{2}{c}{ Improved Scenario } \\
\cline { 2 - 3 } Level of Service & Distraction & Attention & & Distraction & Attention \\
\hline LOS A & & & & Group 2 \\
LOS C & Group 1 & Group 1 & & Group 2 \\
\hline
\end{tabular}

\subsubsection{Simulations and Data Collection}

This thesis examines two parameters associated with participants' behavior at selected curve. Punctual speed were collected in selected points along the curve and on nearby tangents. To compare driver's attention with distraction test, drivers' field of view was also assessed measuring participants' sighting time to mirrors and speedometer, as well as the opening angle of view to the main road. Identifying traffic density at the curve was possible by video recording simulation. Whether it was a car following or free flow situation depends of the quantity of vehicles in front of participant during simulation, and this information was provided by recordings.

It was performed univariate analyses on each dependent measure using paired or unpaired t-tests. A significance level of $p<0.05$ was adopted for all inferential tests. 



\section{Results}

The results obtained from the pilot study were considered as initial parameters to configure the driving activity and the level of service of the simulation. It was decided that the PASAT should be conducted with a higher frequency rate and a heavy traffic simulation to increase the required mental workload. The sections of this chapter present the results according to each analysis.

\subsection{Average Speed According to the Road’s LeVel of Service}

The first analysis consisted of finding the level of traffic that would be applied in the distraction task. The overall scenario can be found in Figure 8 , where is found the average speed profile of drivers from KM 5.000 to KM 8.000 of the virtual road. Similarities in drivers' speed profile are found according to curves and tangents in this stretch and it can also be observed a lower average speed in LOS E simulations. Despite variations between LOS A and LOS C, the highest speed in the road varied for these two traffic densities.

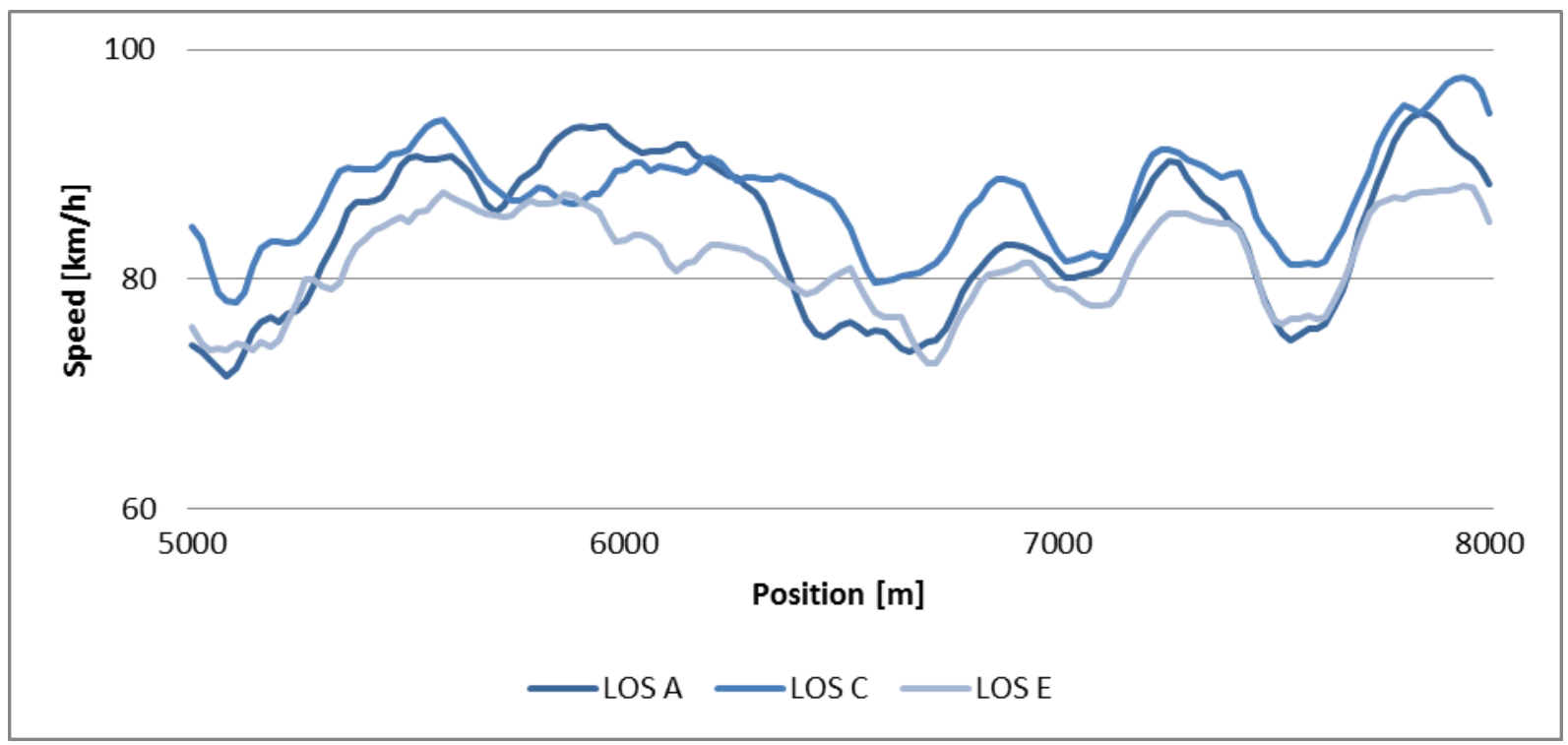

Figure 8. Variations in the average speed according to the level of service. 
Figure 9 shows drivers' punctual speeds only for the selected curve of analysis. It still presents the difference between drivers' behavior according to the three levels of service defined for the simulation. The horizontal axis shows the distance to the beginning of the curve identified by the value 0 in the dotted lines. Furthermore, the end of the curve is found crossing the axis at $200 \mathrm{~m}$ and it is identified with dotted lines as well. From the total of 21 participants belonging to Group 2 who performed the experiment, 3 were excluded for not being able to control the virtual vehicle, or were involved in a car crash in any of the simulations. Therefore, 9 results were excluded from the analysis, as the same participant took part in three simulations with different levels of services. Graphical analysis of this situation reported similar speed developments among the different level of services.

A statistical paired t-test was used three times to obtain the drivers' punctual speed. Comparisons were made between: LOS A with LOS C, LOS A with LOS E and LOS $C$ with LOS E. The first comparison rejected different average speeds from participants while in LOS A or LOS C scenarios for all points, except $150 \mathrm{~m}$ ahead of the curve.

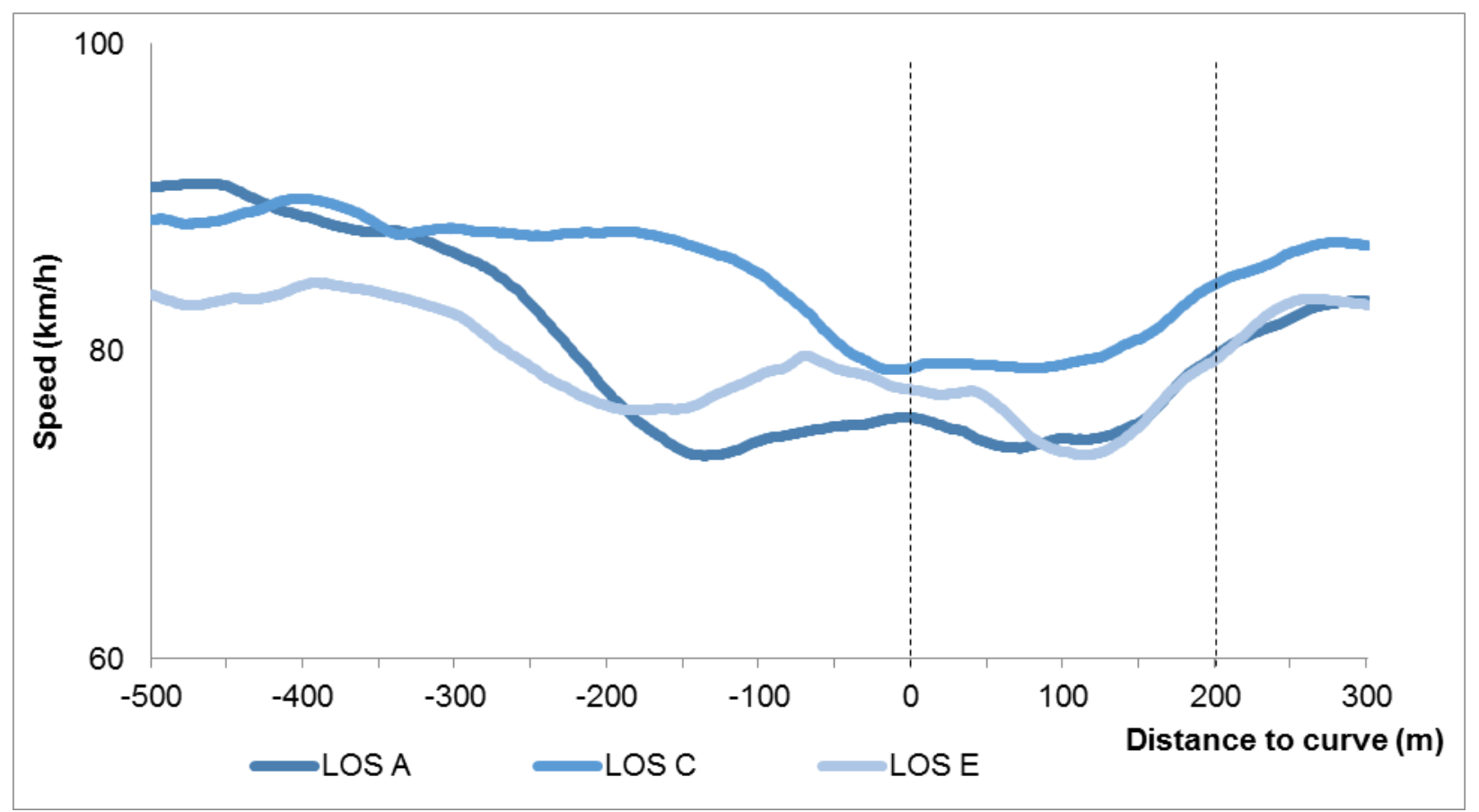

Figure 9. Average speed of Group 2 in different LOS scenarios. 


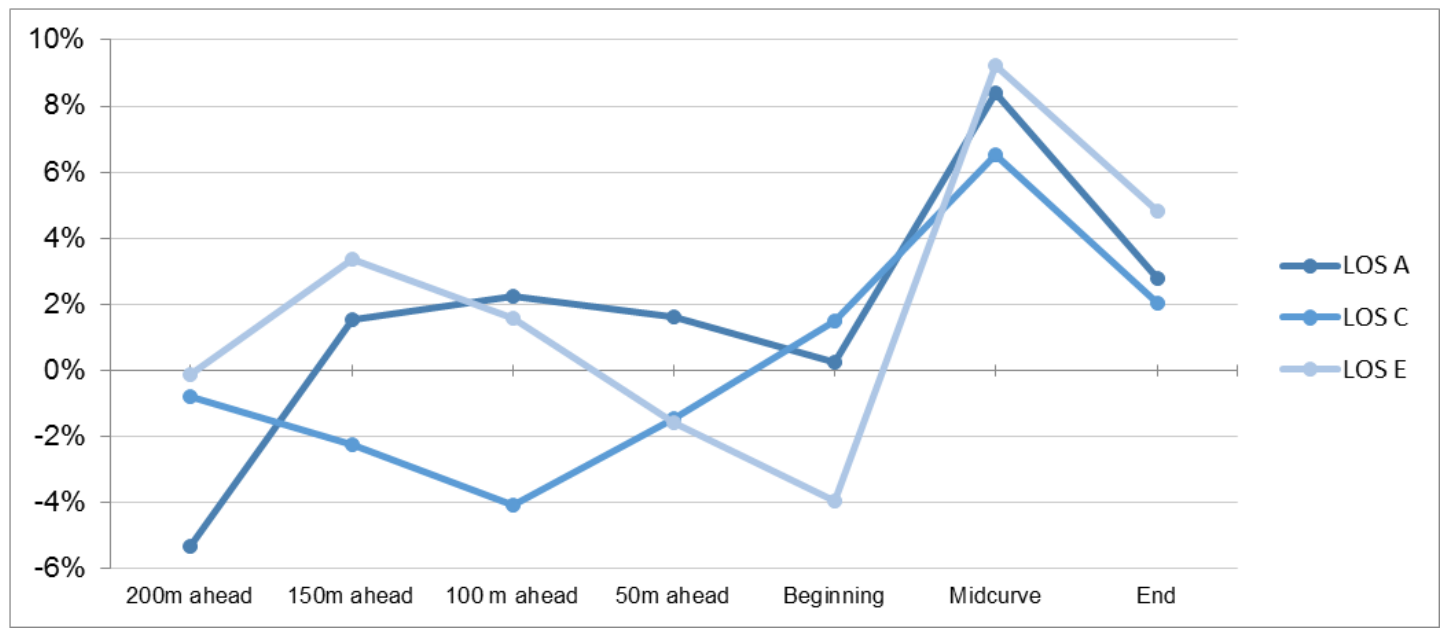

Figure 10. Average speed variation from point to point in different traffic densities

The difference in velocity at this point is because the drivers attained the lowest average speed of $150 \mathrm{~m}$ before the curve in the LOS A scenario, while in the LOS C scenario, they were still reducing their speed in this position.

Average speed presents no significant variation between LOS A and LOS E scenarios at any point, and a similar speed profile for the whole path is considered. When LOS C was compared to LOS E, the average speed was significantly different, $200 \mathrm{~m}, 150 \mathrm{~m}, 100 \mathrm{~m}$ before the curve and at the beginning of the curve. This result can be observed in Figure 10 showing the speed variation from one site to another.

Whereas the drivers accelerated between the $200 \mathrm{~m}$ to $100 \mathrm{~m}$ points before the curve and braked at the beginning of the LOS E simulation, their behavior was exactly the opposite when they drove in the traffic simulation classified as LOS C.

Figure 10 also provides information about the maximum deaccelerating rate reached at different positions ahead of the curve for each situation. Whereas the drivers braked the most $200 \mathrm{~m}$ before the curve at a rate of $5.3 \%$ in simulation $A$, in simulation $\mathrm{C}$ this braking occurred $100 \mathrm{~m}$ before the curve at a rate of $4.1 \%$, and was $4 \%$ immediately before the beginning of the curve in simulation $\mathrm{E}$.

The main reason for not having a significant variation between these scenarios, except for the position when braking started is due to the limitations of the simulator to generate traffic. The simulator's software determines an average traffic zone around the driver according to previously defined parameters. However, this traffic zone does not determine a situation that is maintained for the whole simulation at all 
times. The participants in the simulation were able to break through the traffic zone generated by the simulation, and then found themselves in a free flow zone until a new traffic zone was generated around them, ensuring the initial conditions. Therefore, even with the traffic configuration of the LOS E scenario, the participants drove in free flow zones in $38 \%$ of simulations in the stretch of the curve, which characterizes a $\mathrm{C}$ level of service or even an $\mathrm{A}$ level.

Thus, the next density analyses considered the flow condition around the drivers during the curve, i.e. if the drivers drove in a free flow or a car following situation. Figure 11 shows the number of participants that were in a free flow zone while driving at the beginning of the curve for each LOS scenario. If there was a car in front of the driver with a headway smaller than 9 seconds, the situation was classified as a car following condition (BROWN, 1999), regardless of traffic density previously set.

Instead of using the simulation setup of traffic according to the density of traffic, all the simulated data collected were separated according to the surrounding traffic while drivers performed the curve in analysis. If drivers are in a car following situation, it means that participants' speed is no longer the one they feel safe or intend to drive, but the speed in which they can keep a safe distance to the car ahead and therefore, the speed of the car ahead. The driver's intended speed is only found while in a free flow scenario.

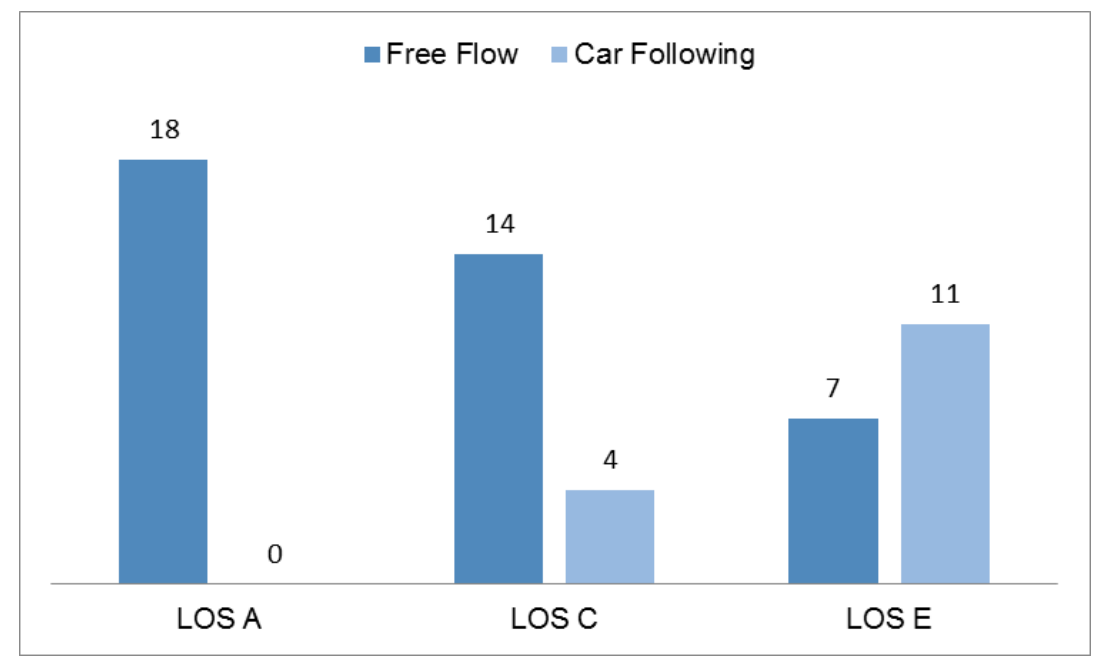

Figure 11. Driver's situation performing the curve, according to the traffic ahead 


\subsection{Average Speed According to Curve’s LeVel of Service}

New analyses followed the classification of drivers according to the traffic flow. From a total of 54 simulations, 39 were classified as a free flow situation and 15 as a car following situation while performing the researched curve. At first, analyses were for each traffic flow regardless of the initial flow configuration, and then for level of service considering the classifications of free flow or car following situations.

Figure 12 represents the speed profile for the first analysis. In both situations, speed profile considered a selected point from $200 \mathrm{~m}$ ahead of the curve to $50 \mathrm{~m}$ after it. For these sites, a decrease in the punctual speed is expected from $200 \mathrm{~m}$ ahead of the curve until the middle of its development, and an increase in speed from this point to $50 \mathrm{~m}$ after the curve's end in a free flow condition.

In the continuous flow simulations (synchronous), the tendency of the drivers was to reduce speed to turn the curve, as well as in the free flow. However, the main influence on the speed profile was that there was a possibility to overtake the vehicle in front or the need to maintain a safe distance from the vehicle. Figure 12 and Figure 13 present the car following speed profiles for LOS C and E simulations.

No statistical analyses was carried between the LOS C and LOS E simulations shown in Figure 11, as the drivers' behaviour is only identified when they are driving freely at the desired speed. For the same reason, the comparison of the speed profile between the flow and the car following, shown in Figure 12, is merely graphical.

The last comparison considers situations of free flow in a simulation according to the level of service (Figure 14). A paired t-test for this analysis was no longer performed as the number of samples in each group was no longer equal. The test was substituted by an unpaired t-test assuming unequal variance, as participants in each group tested differed.

In free flow, the feel of the real level of service transmitted to the user varies between the levels A, B or even C. These levels correspond to free flow, near the free flow or almost free flow. These levels are independent of the initial parameters of the traffic simulation (LOS A, LOS C or LOS E). 


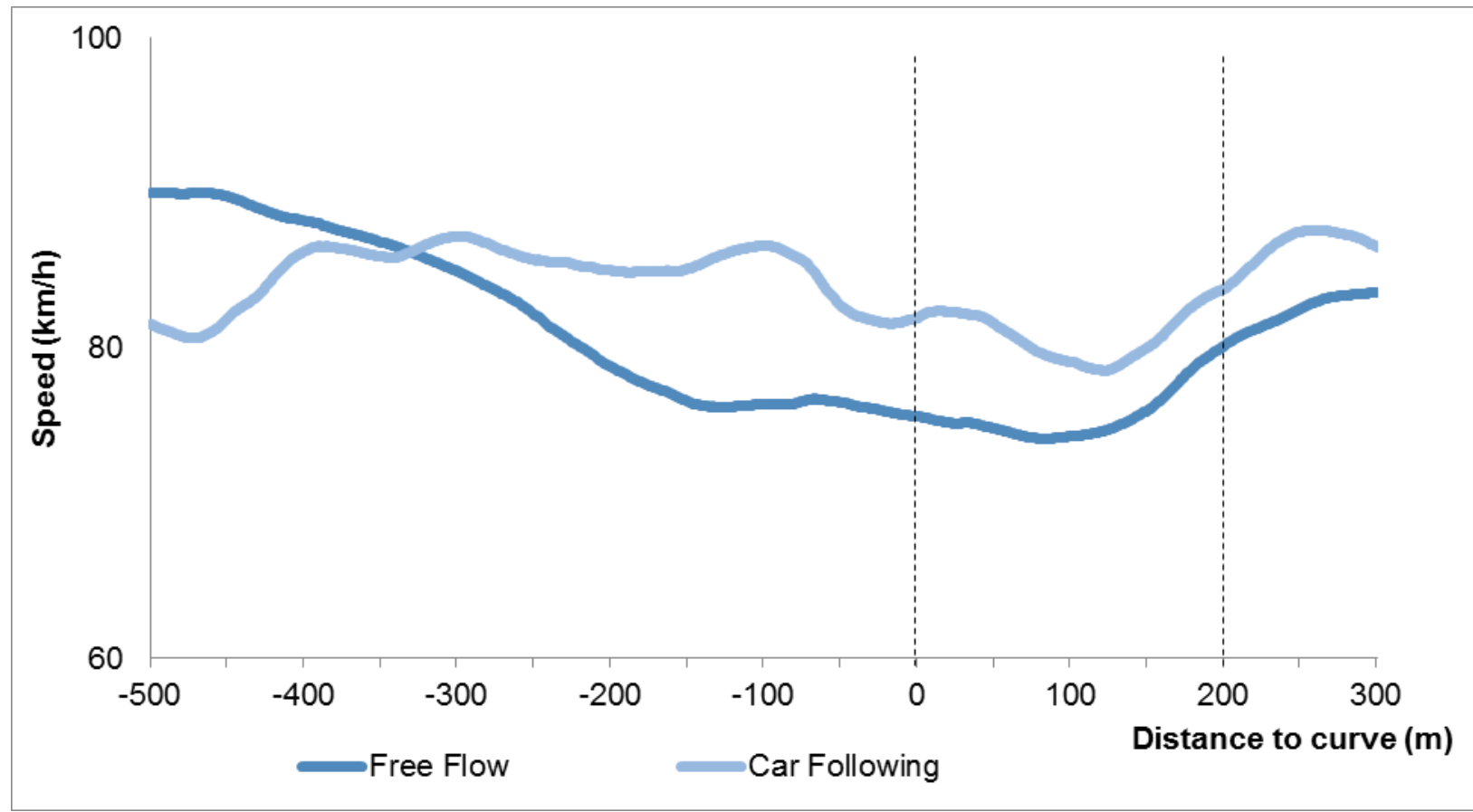

Figure 12. Average speed according to curve flow

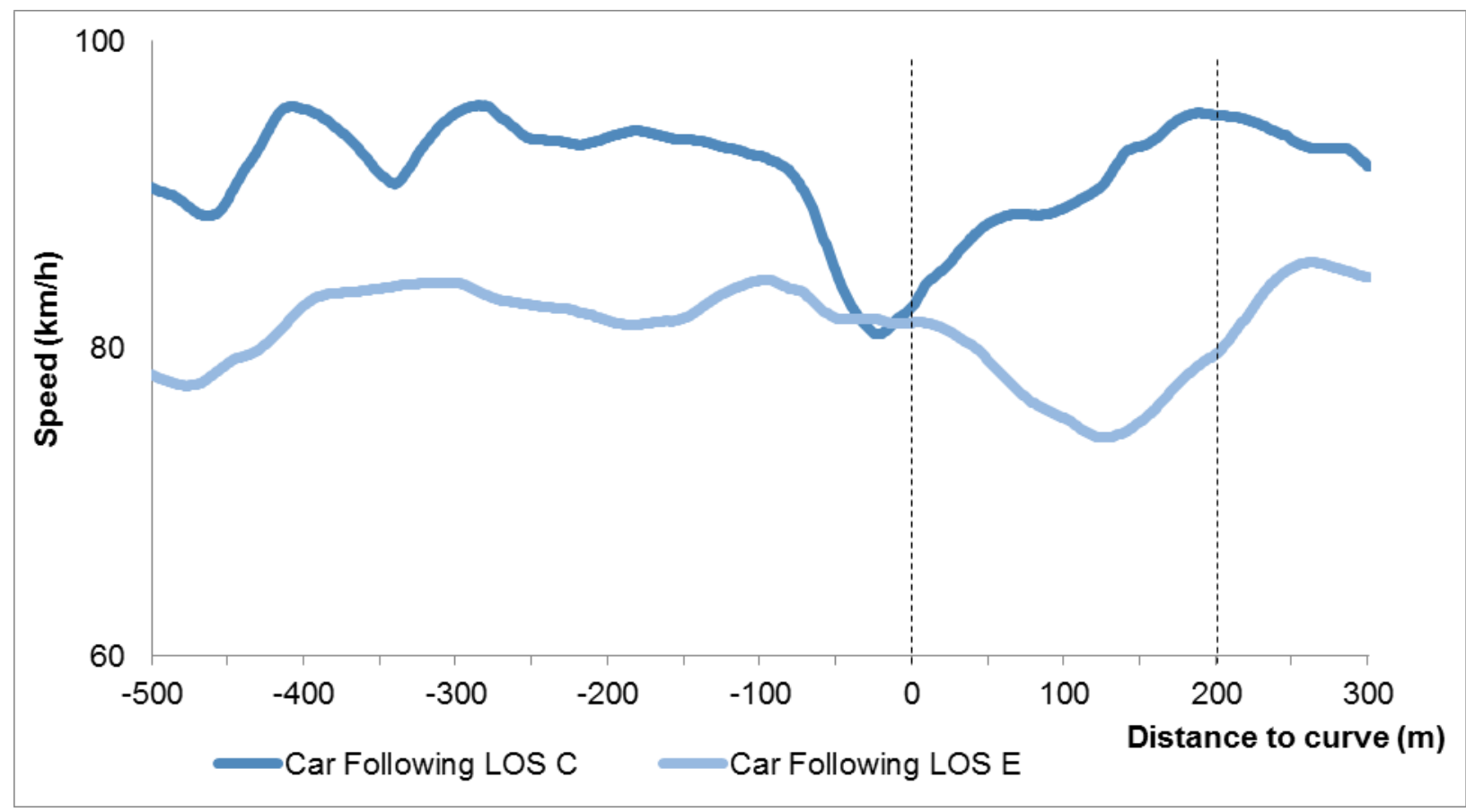

Figure 13. Average speed according to LOS, considering car following flows 


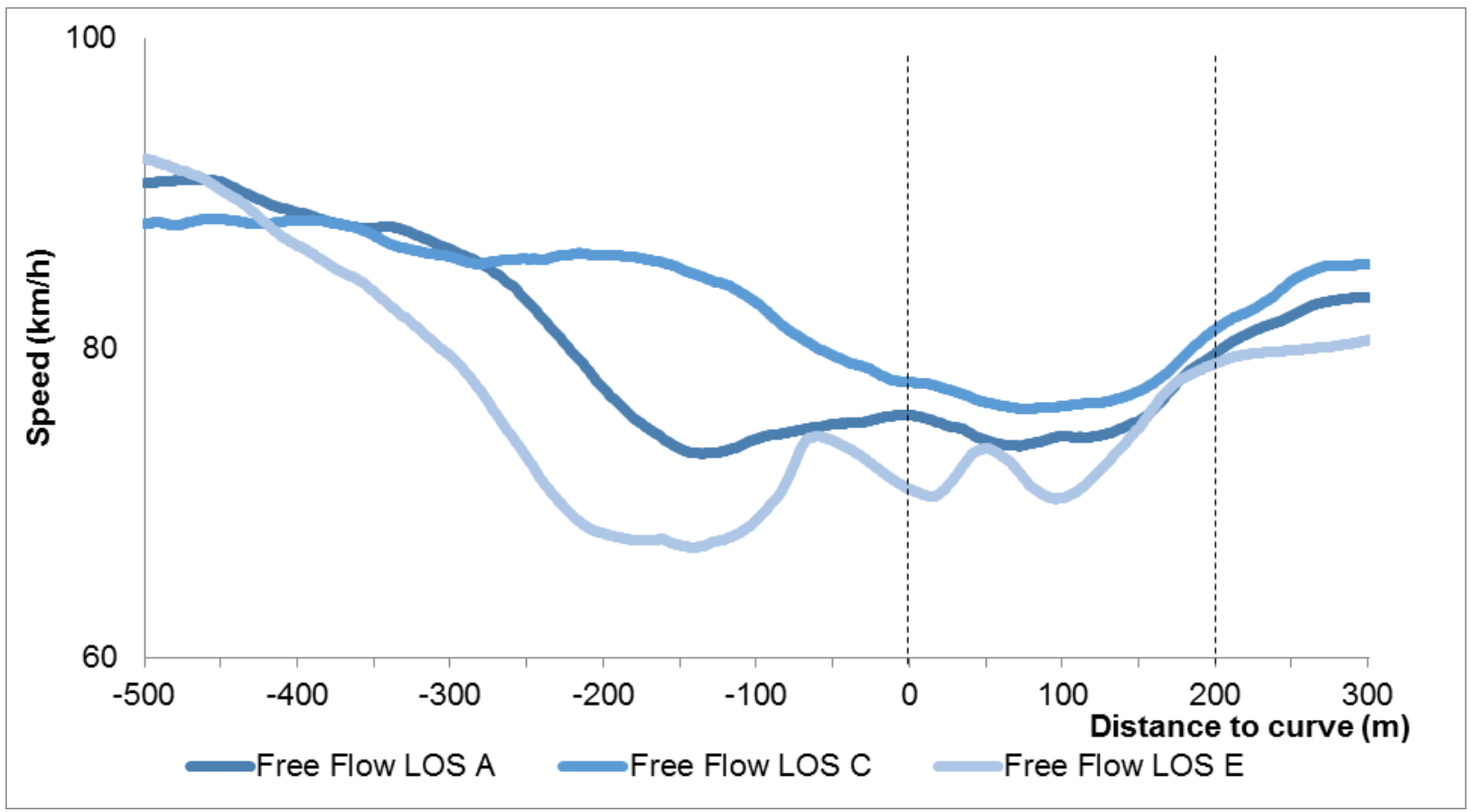

Figure 14. Average speed according to LOS traffic and considering only free flow
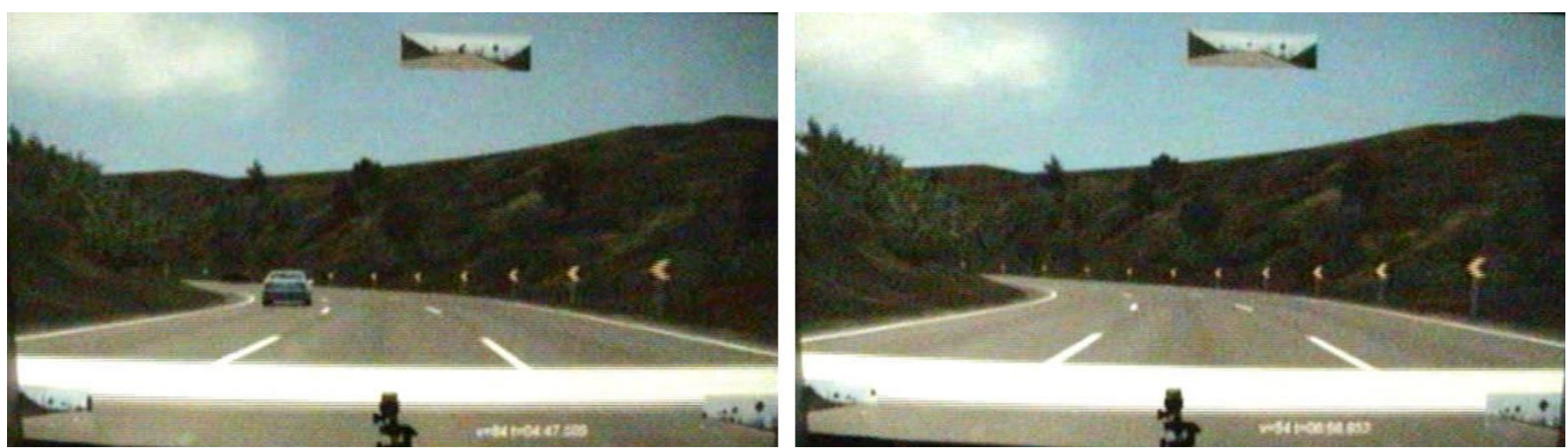

Figure 15. Examples of free flow, with or without vehicles in other lanes and headway requirement achieved

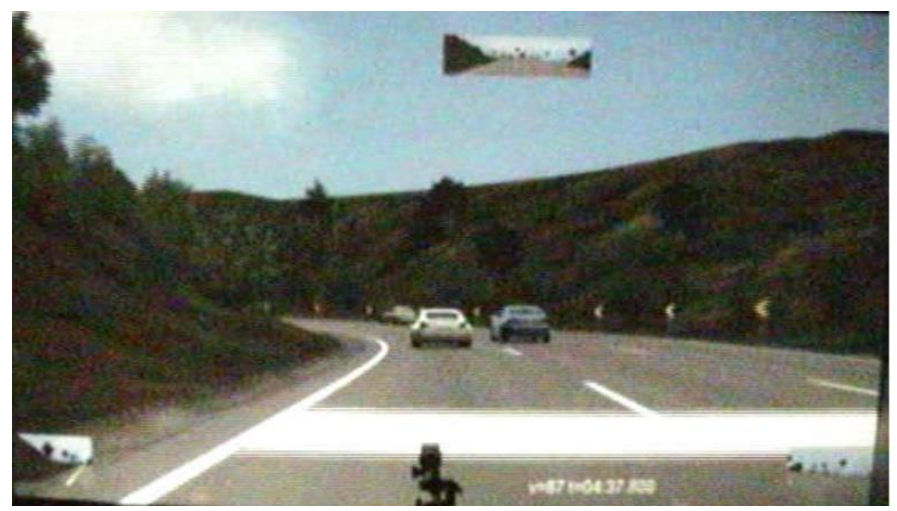

Figure 16. Example of car following flow 
It is hard to exactly define the level of free flow considering only the headway to the vehicle ahead, as the level of services considers parameters other than headway only. Figure 15 illustrates free flow situations. The presence of other vehicles in adjacent lanes to the one used by the participant may change the level of service of the user, but are still considered free flow. Figure 16 is an example of synchronous flow, with a vehicle in front of the participant with a headway less than 9 seconds.

Statistical analysis found no significant variations in speed when comparing the simulations in free flow of the LOS E scenario with the values obtained in the LOS A and LOS $C$ simulations. While the drivers varied their speed abruptly in the simulations in LOS E, the speed profile of the simulations in LOS C had a smooth change, similar to the free flow profile and statistically similar to that obtained in the LOS A simulations.

As the simulations in free flow with the traffic parameters of the LOS E scenario are characterized as 'almost free flow', and the classification of this variable was carried out exactly at the beginning of the curve, the other points located before and after may not present the minimum conditions of free flow, but were misclassified.

These results were based on the definition of the flow of vehicles that was applied in the distraction test. A free flow density is not presented as so low as in the LOS A simulations, but high traffic densities do also not occur as found in the LOS E simulations, which influenced the speed profile of the drivers.

\subsection{AVERAGE SPEED ACCORDING TO MENTAL WORKLOAD}

The second main analysis consists of comparing the driving activity while in full concentration with the simulation where participants were partially distracted by the PASAT workload test. Seventeen participants drove twice in the same simulated scenario; once when they were fully attentive and had no distractions and the other responding to the PASAT randomly. Three participants were omitted for not being able to complete both simulations. Two of them overturned the simulated vehicle and the other one could not adapt to the vehicle control. Figure 18 shows the speed profile for the 14 participants from group 1 according to the PASAT. 
A graphic interpretation of the speed profiles show that the drivers without secondary increased their speed in the tangent before the curve, attempting to maximize their performance. This increase in the average speed reached the maximum value of 120 $\mathrm{km} / \mathrm{h}$ before the beginning of the curve, which is when the drivers began to brake the vehicle until the middle of the curve.

Participants tended to keep their speed constant while responding to PASAT, even after the beginning of the curve. A reduction in the average speed was observed after the curve had already begun, when the drivers found themselves in an unsafe situation. At this moment, the drivers' attention went back to the test for the driving activity when they attempted to correct the trajectory and adjust the speed to turn the curve.

The paired t-test shows that, statistically, the difference in the mean speed comparing the simulations with and without distraction is significant until $50 \mathrm{~m}$ before the curve, which makes it identical after this point. At this point, the drivers' average speed without distraction reduced to the same levels as their average speeds during the test, which generally remained constant throughout the distraction activity.

As indicated in a previous analysis, the car following influence should be removed from the analysis to assess the curve speed profile. After selecting the simulations with the drivers only in free flow, the speed profile is shown in Figure 19, and corresponds to 10 simulations without workload distraction and 6 simulations with the PASAT.

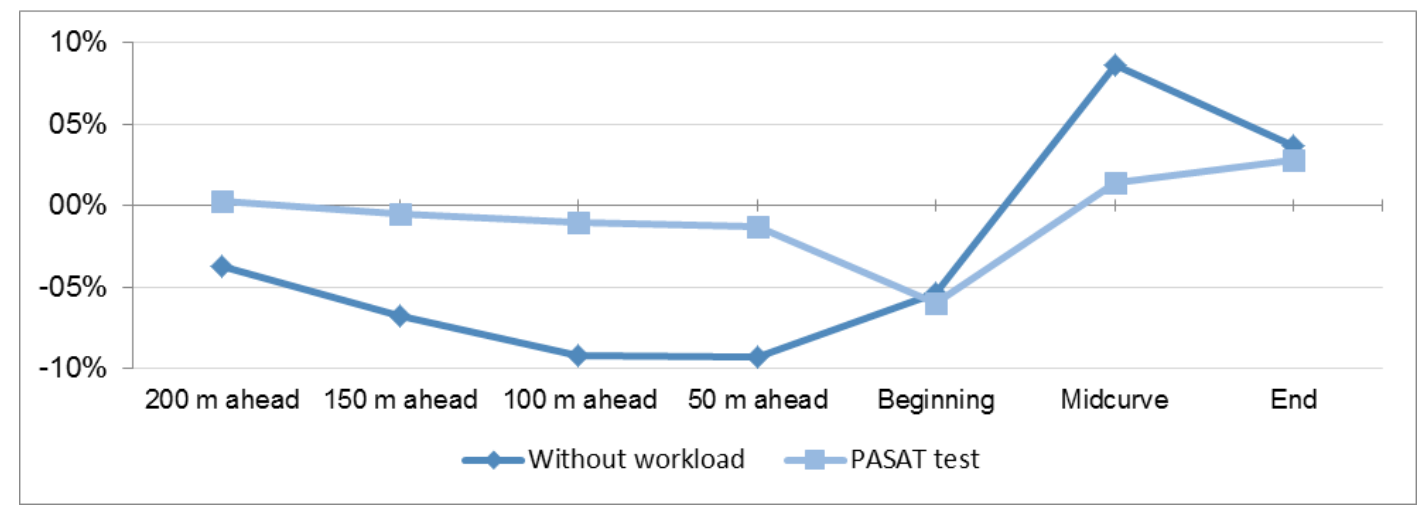

Figure 17. Speed variation from actual position to next site 


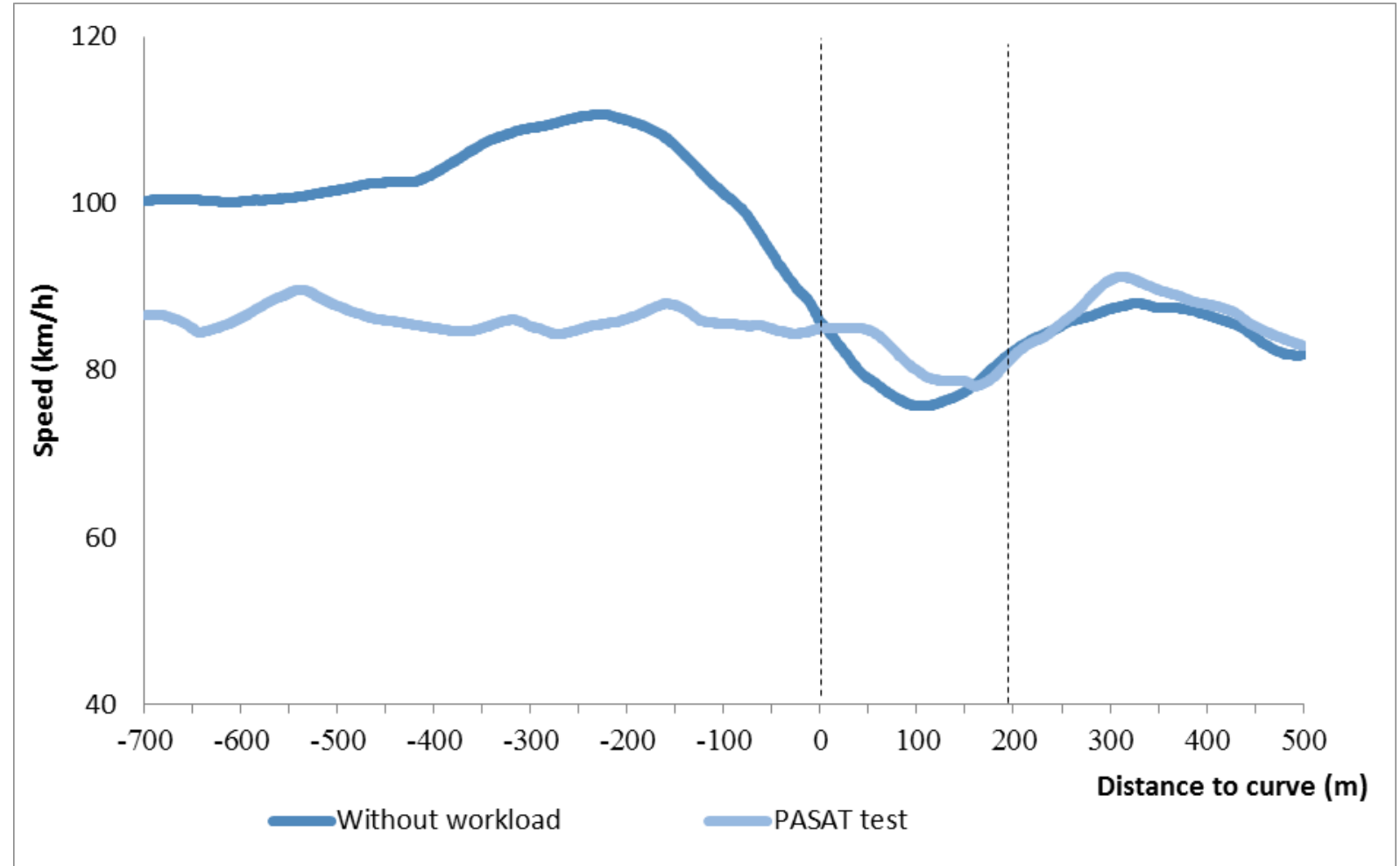

Figure 18. Speed profiles comparing all drivers' simulations without workload with results in the PASAT

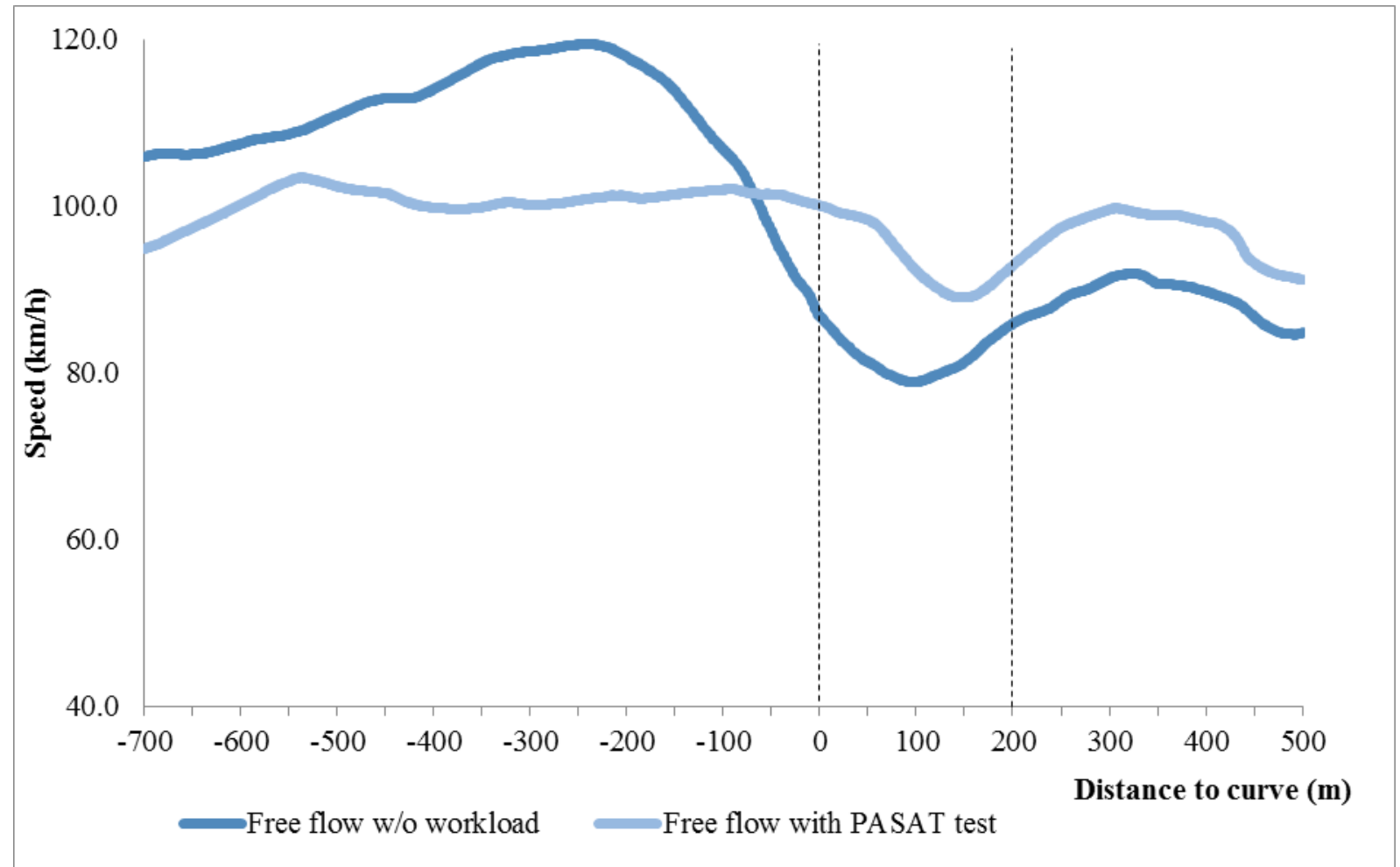

Figure 19. Speed profiles comparing drivers without workload with the test application only for free flow simulations 
Table 5. Drivers' speed variation in free flow from one position to the next

\begin{tabular}{|c|c|c|c|c|c|c|c|}
\hline $\begin{array}{c}\text { Conductor } \\
\text { number }\end{array}$ & $\begin{array}{c}200-150 \mathrm{~m} \\
\text { ahead of } \\
\text { curve }\end{array}$ & $\begin{array}{c}150-100 \mathrm{~m} \\
\text { ahead of } \\
\text { curve }\end{array}$ & $\begin{array}{c}100-50 \mathrm{~m} \\
\text { ahead of } \\
\text { curve }\end{array}$ & $\begin{array}{c}50-0 \mathrm{~m} \\
\text { ahead of } \\
\text { curve }\end{array}$ & $\begin{array}{l}\text { Begin } \\
\text { to } \\
\text { middle }\end{array}$ & $\begin{array}{l}\text { Middle } \\
\text { to end }\end{array}$ & $\begin{array}{l}\text { End to } \\
50 \mathrm{~m} \\
\text { after }\end{array}$ \\
\hline & \multicolumn{7}{|c|}{ ATTENTIVE } \\
\hline \#02 & $-2,2 \%$ & $-7,3 \%$ & $-27,0 \%$ & $-22,9 \%$ & $15,2 \%$ & $21,1 \%$ & $-4,8 \%$ \\
\hline \#03 & $-6,9 \%$ & $-4,8 \%$ & $-4,4 \%$ & $-4,5 \%$ & $-25,5 \%$ & $0,8 \%$ & $20,4 \%$ \\
\hline \#04 & $-2,2 \%$ & $0,4 \%$ & $0,9 \%$ & $-8,5 \%$ & $-32,3 \%$ & $21,5 \%$ & $9,6 \%$ \\
\hline \#05 & $-5,3 \%$ & $-7,6 \%$ & $-7,0 \%$ & $-19,2 \%$ & $-14,0 \%$ & $38,0 \%$ & $-0,7 \%$ \\
\hline \#07 & $-16,6 \%$ & $-28,2 \%$ & $-17,2 \%$ & $1,1 \%$ & $32,4 \%$ & $-7,6 \%$ & $-10,1 \%$ \\
\hline \#09 & $0,8 \%$ & $-3,2 \%$ & $-6,9 \%$ & $-11,2 \%$ & $-18,2 \%$ & $-2,7 \%$ & $3,2 \%$ \\
\hline$\# 11$ & $-2,6 \%$ & $-3,9 \%$ & $-12,5 \%$ & $-11,0 \%$ & $3,4 \%$ & $12,1 \%$ & $8,2 \%$ \\
\hline$\# 12$ & $-2,3 \%$ & $-0,2 \%$ & $-2,5 \%$ & $-5,9 \%$ & $-6,4 \%$ & $0,8 \%$ & $2,8 \%$ \\
\hline$\# 13$ & $-1,1 \%$ & $-1,2 \%$ & $-2,4 \%$ & $-10,6 \%$ & $-14,0 \%$ & $-1,2 \%$ & $2,5 \%$ \\
\hline$\# 14$ & $1,7 \%$ & $-11,7 \%$ & $-13,5 \%$ & $0,1 \%$ & $5,8 \%$ & $3,4 \%$ & $6,0 \%$ \\
\hline \multirow[t]{2}{*}{ Speed variation } & $-3,7 \%$ & $-6,8 \%$ & $-9,2 \%$ & $-9,3 \%$ & $-5,4 \%$ & $8,6 \%$ & $3,7 \%$ \\
\hline & \multicolumn{7}{|c|}{ DISTRACTED } \\
\hline \#02 & $2,2 \%$ & $1,7 \%$ & $0,7 \%$ & $1,1 \%$ & $-13,3 \%$ & $-5,1 \%$ & $6,1 \%$ \\
\hline \#05 & $-2,0 \%$ & $1,3 \%$ & $-4,1 \%$ & $-7,7 \%$ & $-6,9 \%$ & $13,9 \%$ & $9,3 \%$ \\
\hline$\# 09$ & $2,3 \%$ & $2,0 \%$ & $2,0 \%$ & $1,6 \%$ & $0,6 \%$ & $4,7 \%$ & $3,7 \%$ \\
\hline$\# 12$ & $-0,4 \%$ & $0,0 \%$ & $0,5 \%$ & $-1,1 \%$ & $-15,3 \%$ & $-6,4 \%$ & $8,2 \%$ \\
\hline$\# 13$ & $-0,5 \%$ & $-0,6 \%$ & $-0,5 \%$ & $-0,6 \%$ & $-1,8 \%$ & $-1,1 \%$ & $-0,1 \%$ \\
\hline$\# 15$ & $0,1 \%$ & $-0,5 \%$ & $-1,0 \%$ & $-1,3 \%$ & $-6,0 \%$ & $1,4 \%$ & $2,8 \%$ \\
\hline Speed variation & $0,3 \%$ & $-0,5 \%$ & $-1,0 \%$ & $-1,3 \%$ & $-6,0 \%$ & $1,4 \%$ & $2,8 \%$ \\
\hline
\end{tabular}

The unpaired t-test was applied to the speed variation values from one site to the next position. These variations are presented in Table 5 for those participants beginning the curve in a free flow condition (Figure 17). Statistical analysis results show that while drivers decreased their speed from 200 m before the curve until the beginning under no secondary distraction, they kept their speed constant while solving the PASAT. The drivers' behavior was only statistically identical during the curve trajectory for both situations: they reduced their speed until the middle of the curve, then increased it until $50 \mathrm{~m}$ after the end.

\subsubsection{DRIVERS' BEHAVIOR WITH MENTAL WORKLOAD TEST}

Further analysis concerning the drivers' behavior, comparing mental distraction with total awareness when driving, includes the average speed for the whole simulation, 
the driver's ability to control the steering wheel, the number of gear changes and eye tracking data (Table 6). Despite the variation in traffic density during the simulation, these analyses include the simulation as a whole, so that punctual variations throughout the scenario do not interfere significantly in the initial definitions of the simulation control. For this reason, it is not necessary to consider car following or free flow category for these comparisons.

The drivers' average speeds during the whole simulation were lower while they were solving the PASAT. The participants developed an average speed of $84.8 \mathrm{~km} / \mathrm{h}$ without distraction, and this value was $78 \mathrm{~km} / \mathrm{h}$ in the PASAT. A Pearson correlation of 0.81 is considered a high value for this comparison.

The average total of gear changes made by each participant was 15.6 times while in full concentration, compared to 8.6 times during the PASAT. The first gear changes caused by acceleration at the beginning of the simulation were discarded. The considered gear changes were those made during the PASAT and its corresponding position in the simulation without distraction.

The difference in the total number of lane changes was not considered significant statistically, although drivers had overtaken vehicles many times and changed lanes without the PASAT application (6.3 times overtaking while in full attention, 4.5 times overtaking during distraction). A high value in lane change variance is due to some drivers maintaining the vehicle in the same lane during the whole simulation and others overtaking many times during simulation.

Eye tracking data shows whether drivers were paying attention to rear mirrors and the speedometer while turning the curve, and the dispersion of the driver's field of vision for the whole scenario. Table 7 shows a statistical analysis for the drivers' sight in the rear mirrors. The attention to the speedometer follows the same distribution, reducing from 6.3 seconds while attentive to 4.5 seconds distracted. Table 8 compares the participants' FOV with and without the distraction test. 

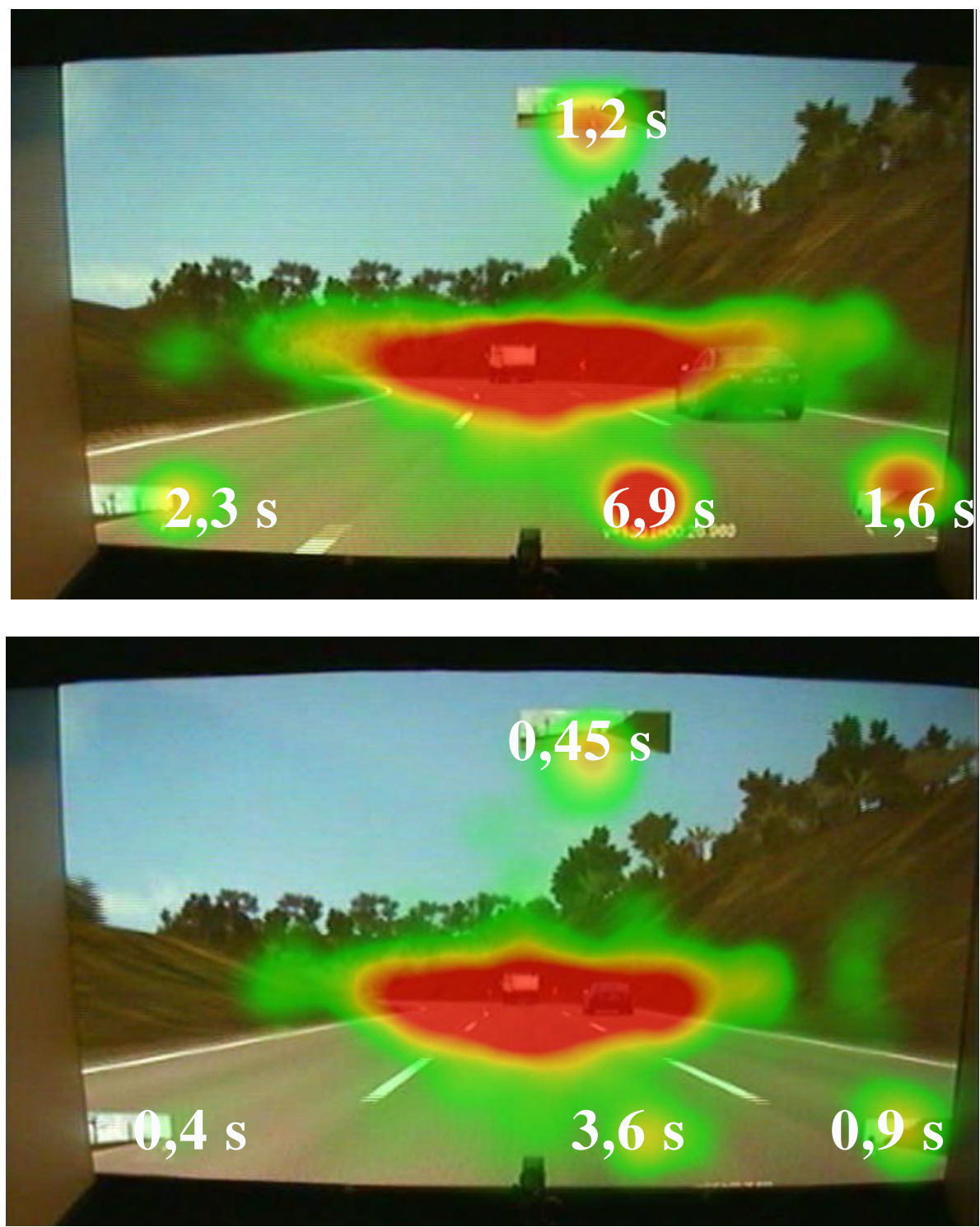

Figure 20. Driver's FOV at curve with corresponding time for each element (a) without mental workload and (b) answering the PASAT

Considering the total time of observations to elements in projection (rear mirrors and speedometer), the drivers' attention was half the normal while distracted. The total time looking at rear views decreased from 5 seconds, while performing the curve and tangents, to glances that totalize 1.72 seconds. Drivers observed the speedometer for 3.55 seconds, but this value represents almost half of the total of 6.91 seconds in the simulations they were fully concentrated on.

The horizontal and peripheral FOV were 28 and 19 pixels narrower in the PASAT, compared to fully attentive drivers. It represents a decrease in the field of vision, and consequently to the elements of the scenario, but without statistical significance. 
Figure 20 illustrates an example of the driver's FOV at a curve trajectory. A light green area indicates observations of less than a second; yellow means between 1 to 3 seconds; orange, from 3 to 6 seconds; and red, more than 6 seconds. Table 7 illustrates a fully concentrated driver, in free flow driving, observing the left and right mirrors (for less than 1 second, inaccurate precision), between 3 to 6 seconds looking at the speedometer, and FOV around the lane ahead. Figure 20.b is the same driver while distracted. The driver did not look in the left and right mirrors, but spent less than one second looking at the rear view mirror, less time observing the speedometer and the same dispersion for the field of vision.

Table 6. Average speed, total of gear and lane changes for simulations.

\begin{tabular}{|c|c|c|c|c|c|c|}
\hline & \multicolumn{2}{|c|}{ Avg Speed [km/h] } & \multicolumn{2}{|c|}{ Gear changes [total] } & \multicolumn{2}{|c|}{ Lane changes [total] } \\
\hline & Attentive & Distracted & Attentive & Distracted & Attentive & Distracted \\
\hline Average & 84,8 & 78,0 & 15,6 & 8,6 & 6,3 & 4,5 \\
\hline Variance & 155,3 & 69,3 & 64,7 & 31,6 & 15,0 & 9,7 \\
\hline Pearson corr. & \multicolumn{2}{|c|}{0,81} & \multicolumn{2}{|c|}{0,51} & \multicolumn{2}{|c|}{0,54} \\
\hline$P(T<=t)$ & \multicolumn{2}{|c|}{$0,5 \%$} & \multicolumn{2}{|c|}{$0,3 \%$} & \multicolumn{2}{|c|}{$10,9 \%$} \\
\hline
\end{tabular}

Table 7. Total time of elements' eye tracking observations during curve trajectory

\begin{tabular}{lcccccccc}
\hline & \multicolumn{2}{c}{ Left rear view } & & \multicolumn{2}{c}{ Right rear view } & & \multicolumn{2}{c}{ Upper rear view } \\
\cline { 2 - 3 } & Attentive & Distracted & & Attentive & Distracted & & Attentive & Distracted \\
\hline Average $(\mathrm{s})$ & 2,27 & 0,36 & & 1,55 & 0,91 & & 1,18 & 0,45 \\
Variance & 5,22 & 0,85 & & 3,87 & 1,89 & & 2,16 & 0,87 \\
Pearson corr. & 0,56 & & 0,54 & & & 0,01 & \\
$\mathrm{P}(\mathrm{T}<=\mathrm{t})$ & $0,8 \%$ & & $24,0 \%$ & & & $19,5 \%$ & \\
\hline
\end{tabular}

Table 8. Participants' FOV from eye tracking system

\begin{tabular}{|c|c|c|c|c|c|c|}
\hline & \multicolumn{2}{|c|}{ Horizontal FOV } & \multicolumn{2}{|c|}{ Vertical FOV } & \multicolumn{2}{|c|}{ Peripheral dispersion } \\
\hline & Attentive & Distracted & Attentive & Distracted & Attentive & Distracted \\
\hline Avg. Pixel size & 228,4 & 200,3 & 97,6 & 100,8 & 178,6 & 159,3 \\
\hline Variance & $2.336,3$ & $1.714,8$ & 70,5 & 144,6 & $4.191,0$ & $1.315,3$ \\
\hline Pearson corr. & \multicolumn{2}{|c|}{0,36} & \multicolumn{2}{|c|}{$-0,34$} & \multicolumn{2}{|l|}{0,43} \\
\hline$P(T<=t)$ & \multicolumn{2}{|c|}{$9,8 \%$} & \multicolumn{2}{|c|}{$54,5 \%$} & \multicolumn{2}{|c|}{$30,4 \%$} \\
\hline
\end{tabular}




\subsection{AVERAGE SPEED ACCORDING TO THE SELECTION OF THE SCENARIO}

The last comparison aims to identify the variation in the speed profile according to improvements in road design. (CASTILLO, 2015) suggested improvements in sign positions considering the braking minimum distance and safe speed developed in a stretch $\left(\mathrm{V}_{85}\right)$ considering the operational speed.

Only drivers in a free flow situation were considered for this comparison, as well as in a previous analysis. Drivers from Group 1 drove in the previous scenario and drivers from Group 2 drove in the improved signaling according to Rangel's (2015) specifications. The traffic density configuration was the same for both groups (LOS C). Figure 21 illustrates the speed profile for this comparison. This analysis highlights the maximum speed developed by drivers on the tangent ahead of the curve. While drivers in Group 1 reached the maximum average speed of $120 \mathrm{~km} / \mathrm{h}$, participants in Group 2 kept their speed constant at an average rate of $90 \mathrm{~km} / \mathrm{h}$. Consequently, participants in Group 2 started the curve with a lower average speed than the participants in Group 1, even when these participants decelerated the most.

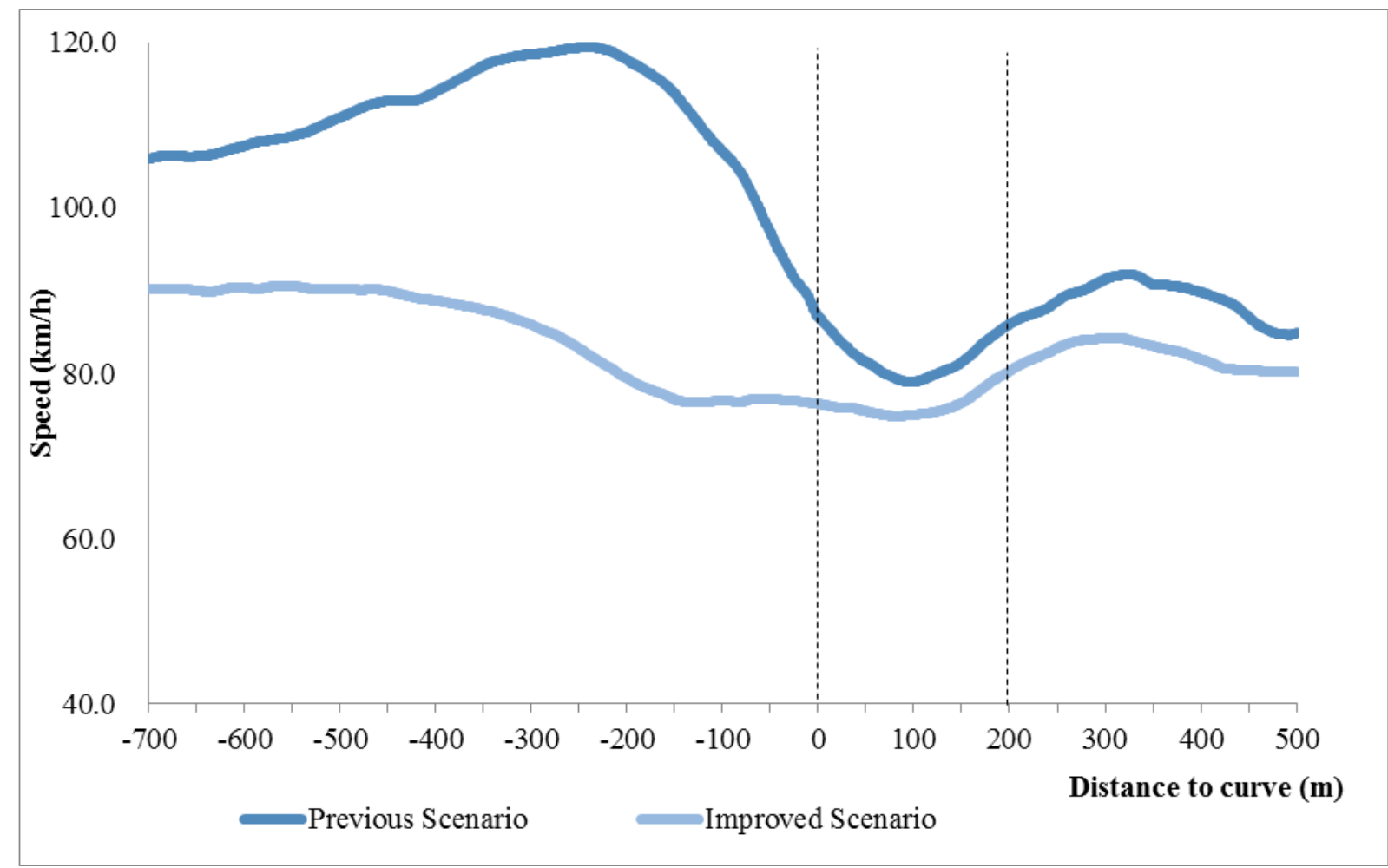

Figure 21. Speed profile according to sign improvements 



\section{Discussion}

In this manuscript, three variables were analyzed to determine drivers' behavior profile to perform a selected curve. This section includes discussion about traffic in simulation design, one subchapter for each of the variables considered and two subchapters about how distraction affects drivers' model behavior and the level of immersion reached by driving simulator.

\subsection{LeVel of Service Configuration}

The first challenge found to develop this thesis was to determine the correct traffic density that could insert difficulty to driving task, but without influencing the speed profiles. As traffic density parameter was not constant, level of service of the highway was changeable either. It was found a software limitation to create and maintain the selected traffic zone for the whole simulation. Even on a situation where traffic was intended to be crowded, according to each participant's developed speed and driver's ability to break through the traffic generated zone, traffic could be classified as a low density in some positions of simulation.

VI-grade's software permits two manners of including traffic to simulations: an automatic manner or by manual configuration. To perform the simulations on this proposal it was used the first setup. The automatic configuration is called "Pulk traffic". It consists of creating a circle area around the participants' simulated vehicle and defining the total of vehicles that are generated at this area. If the driver slow down or speed up faster than other vehicles, those vehicles located out of the generated area disappear and new vehicles are created inside the defined region. If a participant, at any moment, speed up so fast that he passes through all the created vehicles, he enters in a free flow zone, even with a high density configuration. 
This situation is observed in Figure 22. At Figure 22.a the driver identified as "Ego (1)" (yellow labeled) finds himself in the middle of high traffic density (simulated traffic is labeled with red names). At Figure 22.b, Ego was able to leave all traffic behind due to high acceleration. At this situation, participants find themselves in a free flow zone classified as a LOS B scenario, and this configuration is maintained until a next traffic generated zone is found. The generation zone happens in lime green circle around of the drivers, and must be , identified by the green lime circle around (behind and in front of) the driver.
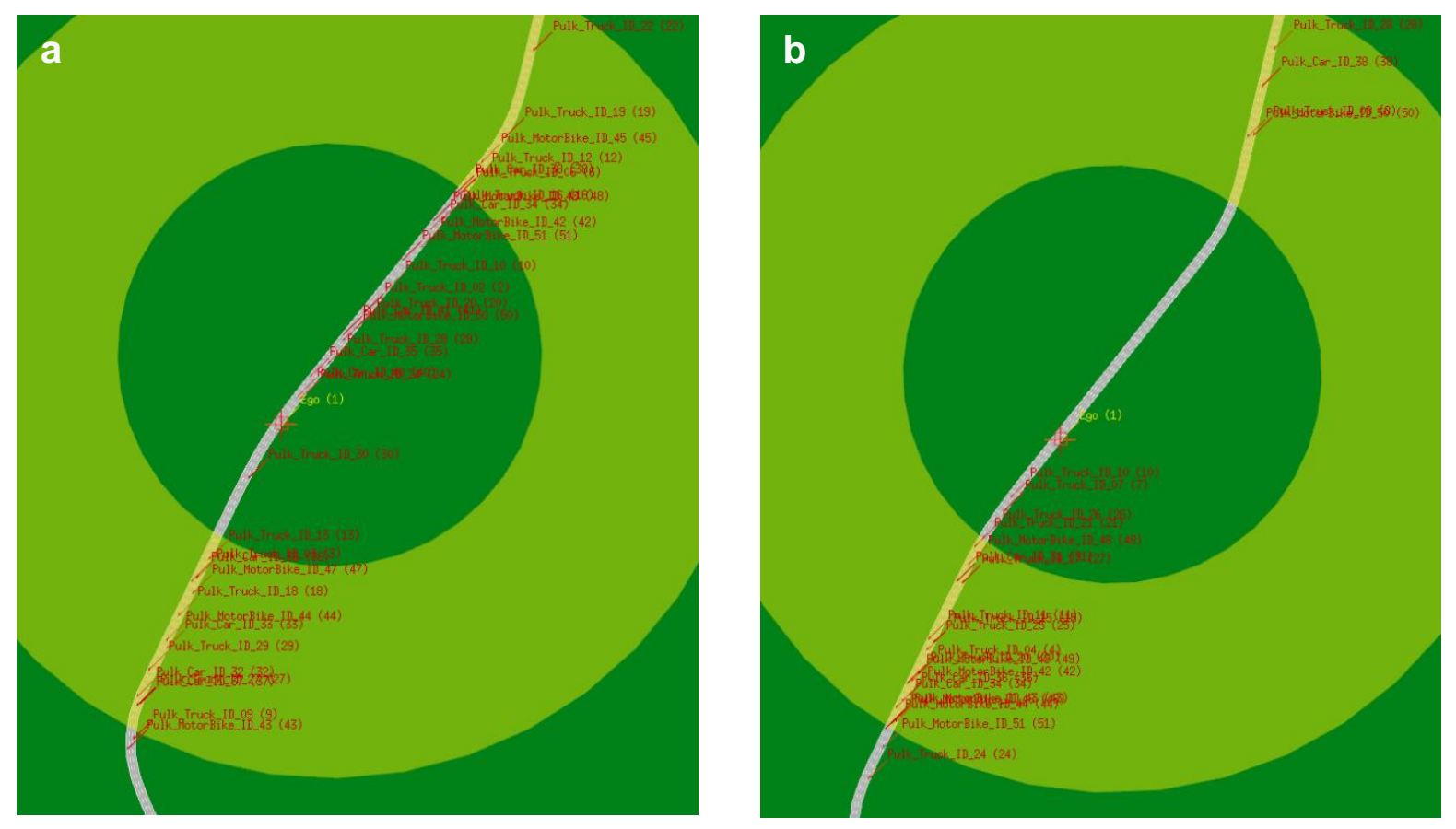

Figure 22. Same traffic density configuration at two different situations: (a) with the driver in the middle of traffic and (b) at free flow between two high density traffic

Even with manual configuration, it's still hard to create a precise scenario that keeps constant level of service for all participants. It's even harder to create an identical scene for both simulations. The main reason is that applicants driving the simulated vehicle have the possibility to press the break or acceleration pedals as long as they wish, as well as perform lane changes through the highway lanes, so they change their position over time randomly, producing a nondeterministic input for software's algorithm.

For using a user's input and operating in a timing-sensitive situation, behave of the algorithm is also classified as non-deterministic. Therefore, losing the ability to 
reproduce the same situation for different simulations is the main disadvantage faced in this project.

\subsubsection{LEVEL OF SERVICE'S COMPARISON}

The first analysis comparing three distinct levels of service resulted in an statistically equal speed profile for the curve. The simulated scenario with LOS E traffic was able to keep these conditions for less than $20 \%$ of the whole simulation. Usually the participants on this scenario found themselves in a LOS D situation, on which the vehicle speeds slightly decrease, the freedom to maneuver within the traffic stream is limited and driver comfort levels decrease (PAPACOSTAS; PREVEDOUROS, 2005), but not in LOS E situation, where shock waves are expected and flow becomes unstable. Some drivers could even find themselves in a LOS C situation, with reasonable free flow traffic.

The only situation on which the simulation setup keeps its promises on the selected traffic service is on LOS A situation. For generating low quantity of vehicles in simulation, even if the driver breaks the traffic generation zone, he still finds himself in a LOS A traffic situation, in other words, with no one or with few vehicles nearby without any influence in drivers' perception.

Further analysis to examine driver's behavior in a curve needs to consider traffic density at the moment of the simulation. Simulations were split in two categories: free flow and car following situations, considering only the amount of vehicle nearby the participant while on curve at the moment of its beginning. Under these conditions, a free-flow simulation could be classified as LOS A, B or C traffic densities at set traffic in software. At these levels of service, the traffic flow is considered free flow, or near free flow. Simulation on free flow situations developed the same speed profile while in the curve trajectory and no significant difference were found on statistical analysis, despite of initial simulation's LOS.

At car following situations, where level of service is expected to be $D$ or $E$, its evident a great variability in participants' average speed, as any disruption on traffic flow, such as lane changes or unexpected brakes of other vehicles, may block the driver's 
lane and interferes in drivers' behavior and punctual speed. At this situation, driver's speed is no longer the participant' desired speed, according to his safety and comfortable behavior, but the speed limited from the vehicle in front of him. It's observed an lower average speed in LOS E situations, compared to LOS C simulations, as in an intense traffic situation, any discomposure in traffic flow generate a shock wave.
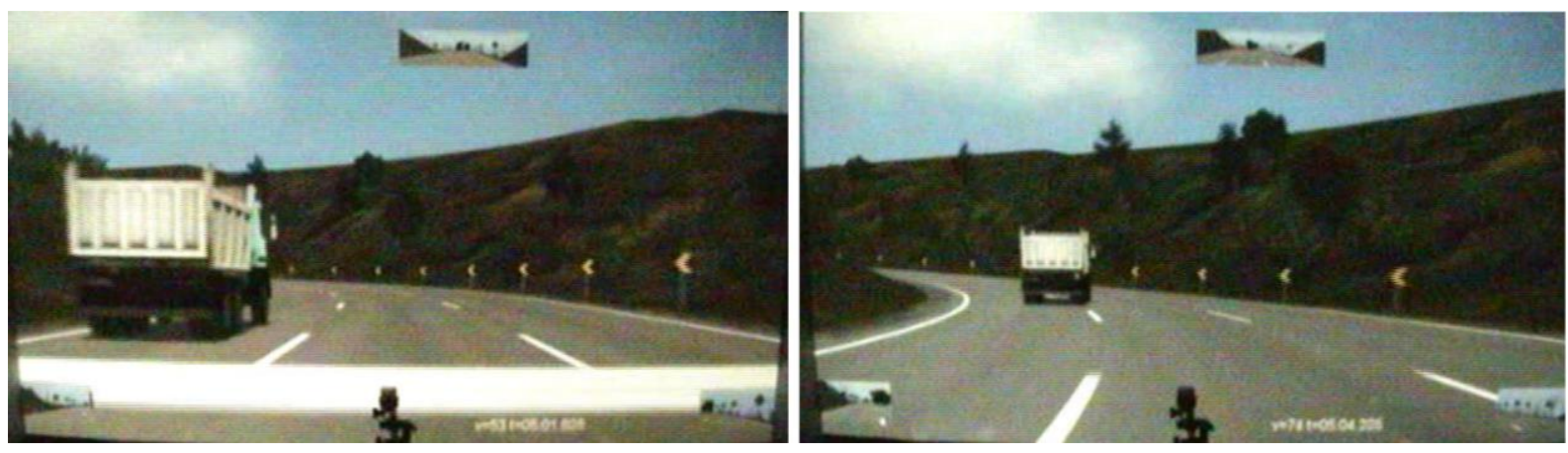

Figure 23. An example of erroneous categorization. A free flow driver at the beginning of the curve is closed by a trucker some seconds later, leading to a car following situation.

It is important to highlight that speed profile where traced considering the situation at the beginning of the curve site. What happened before and after this point may change drivers' behavior. As in the example illustrated at Figure 23. A participant driving in a free flow configuration found himself in a car following seconds later, while developing the curve trajectory. Despite this limitation, these situations did not disturb speed profile developed at this research.

\subsection{Mental Workload Comparison}

The second discussion is about workload distraction comparing simulations. It is notable that drivers' behavior changed at the tangent ahead of the curve while not distracted with PASAT. Even considering those drivers in car following situations, it is observed that drivers tended to optimize their speed while in full concentration to the driving activity. That is, participants increased their speed in the tangent section, but soon decrease it as they anticipate the curve ahead. Even in car following situations, they sought an opportunity to overtake and increase their performance.

While driving answering to distraction test, participants lost their attention to speed control. They developed a safe speed on which it was possible to drive and 
concentrate on test's answer, even while in tangents where they could perform high speed. It was also observed the increased number of car following situations under the task development, as participants preferred to keep a safe distance from another vehicle and reply its actions to focus on test application instead of constantly observing the scenario and setting a safety speed.

Besides the distinct behavior in tangent sections, distracted drivers could only notice the curve when they had already begun perform it. Even driving in a safer and lower speed, they were not able to reduce their speed at the same rate they did while concentrated. That means that their average speed at the curve route was higher than their average speed without the workload.

The discrepancies are even higher when considering only drivers at free flow situations. As they reach the desired speed, the maximum speed on the tangent hit $120 \mathrm{~km} / \mathrm{h}$ at the tangent ahead of the curve. Despite of that, drivers could anticipate the curve and reduced their speed to lower levels when their attention were on the road and not distracted. The average speed in free flow situations were higher than in car following, as conductors tended to use car following as a safety measure to answer PASAT.

\subsection{SCENARIOS' MODIFICATION}

As data from scenario's modification was provided from different samples, results cannot be applied in comparison analysis. This third experiment indicated only a tendency observed in data that may be investigated in future researches, with same sample at group of comparison.

A driver speed profile can only be compared with the same driver's result on other simulation. As well as an average speed profile's group can only be compared with the same group in another simulation. Despite individual results may influence this comparison among groups, the main focus on improving road signaling is to reduce drivers' speed and improve road safety. On both simulations, higher visibility to the curve generated a lower high speed on the tangent ahead. Figure 24 presents 
curve's signaling $500 \mathrm{~m}$ ahead of it beginning. The prior perception of the curve may influence on driver's decision to reach high speed.

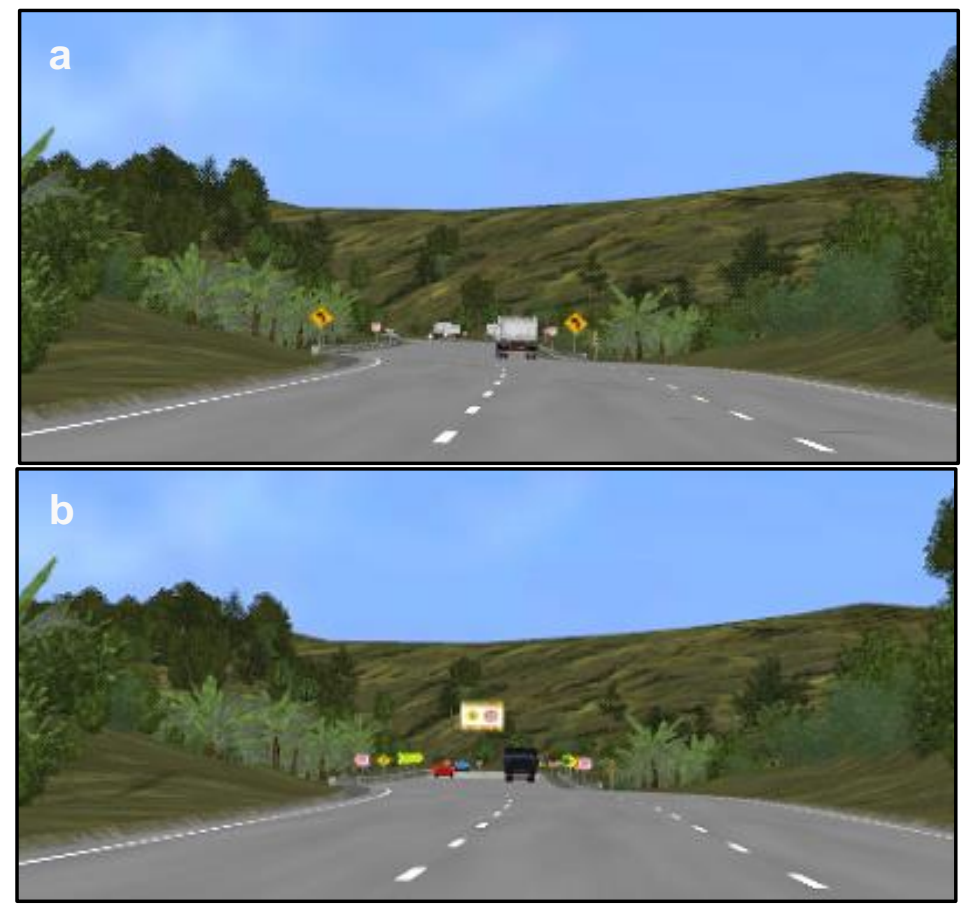

Figure 24. Simulation of curve signaling from $500 \mathrm{~m}$ before in (a) previous scenario and (b) improved signaling

\section{4. $\quad$ DRIVABILITY INDEX RESULTS}

The three main contributors commented in literature review chapter about DRIVABILITY index are also merged to generate two intermediate factors. The fusion of driver resources and environmental status correspond to driver's workload and between drivers' resources and knowledge generates risk awareness. These factors are the key issues to understand driving performance (PANOU; BEKIARIS; PAPAKOSTOPOULOS, 2006). Risk awareness derives from user's ability to recognize specific risk, as well as his level of attention to spot the risk at time and any possible external support (by advanced driver assistance systems - ADAS) while workload is the total concentration demanded or given by the driver at that moment.

These contributors are combined to embrace DRIVABILITY index (DI) of each individual driver at any given moment of time. The overall $D I$ is calculated through the following empirical formula: 


$$
D I=I R I * \frac{K S I}{2} * \frac{W I}{2} * \frac{E F E+R A I}{6},
$$

where $I R I$ is the individual resources index, $K S I$ the knowledge/skills index, $W I$ the workload index, EFE the environmental factors index and $R A /$ the risk awareness index.

The weighted value given by workload to driver's DRIVABILITY index strengthen results presented in this proposal. In the definition of methodology, it was proposed to keep the same driver in different situations. Applying the index to the results expected, we have same IRI and KSI for a comparison of the situations as it is the same driver under same conditions.

In the first situation, with variations on the traffic density, it's performed alterations only in EFE and consequently RAI varies as well. Environmental factors and the increase of risk awareness represents only $4 \%$ of total weight to the composition of index, so results tends to present less variation.

Analyzing driver's behavior among distracted situations, workload corresponds to a weight of $23 \%$ to driver's driving ability. Results displayed with this comparison where higher than previous one, as expected.

While comparing different scenarios, as an additional research, it was presented a huge variation in the comparisons results. The main reason for the variation is considering an average speed profile of two different groups of drivers. Individual knowledge and skills are responsible for $69 \%$ of users' DRIVABILITY, not only the $8 \%$ caused by environmental changes and increase of risk perception.

Under this analysis, DRIVABILTY index support results extracted from distinct variations in traffic density and workload variation. Results obtained from different scenarios may be resulted by comparison in user's behavior with same samples to investigate the effective variations achieved due to signs and improvements on highway. 


\subsection{Presence Questionnaire}

The last discussion about this proposal relies on driver's perception of immersion in the driving simulator. After the simulations, drivers evaluated the simulator according to the immersion experience (Annex D - Caracterização de Imersão no Simulador).

This questionnaire originally classifies drivers' level of immersion in 7 categories (WITMER; SINGER, 1998): realism, possibility to act, quality of interface, possibility to examine the virtual scenario, self-evaluation in performance of controls, sounds and haptic. Despite of "haptic" evaluation, assessed only in tactile virtual environments, all others categories were measured following LEWIS \& SAURO (2009) system usability scaled for 7 -values measured from 1 to 7 . Table 9 presents driver's self-evaluation of immersion's experience in driving simulator. Considering the intermediate level of driving simulator applied in research, results are reasonable highly valuated, above average. Lowest scored categories, with high standard deviations, are self-evaluation of performance and sounds.

Self-evaluation results from drivers' skills to adaptation on simulator's controls. The total time drivers have to get used to control are enough to simulate, but not enough to fully dominate its mechanisms (SAHAMI; SAYED, 2013). Participants main complain about simulations are related to sound system, which they classifies as bellow the expected in real driving activity.

Table 9. Results from Presence Questionnaire

\begin{tabular}{lcc}
\hline & Average & SD \\
\hline Realism & 5.43 & 0.93 \\
Possibility to act & 5.92 & 0.48 \\
Quality of interface & 5.83 & 0.74 \\
Possibility to explore & 5.19 & 0.80 \\
Self-evaluation of performance & 5.16 & 1.50 \\
Sounds & 5.06 & 1.06 \\
\hline
\end{tabular}




\section{Conclusion}

This thesis proposed to compare drivers' behavior performing a curve segment of a rural highway with and without secondary tasks. The PASAT was applied for this secondary task in order to generate mental workload and distract drivers from the main activity. The road scenario modelled in the simulator of this research was validated with the corresponding real world road by RANGEL (2015). It was identified that driver's behavior in the virtual road was not the same, but has varied with the same tendency in several aspects, such as speed profile and signaling gaze. The corresponding validation of the simulator was related to a relative validation. An observed value under a relative validation may be accepted as an observed tendency, but this value may not be considered as an absolute result for the analysis extrapolation. In the comparison of driver's behavior in simulations, drivers' behavior can generally be extrapolated to the real world under relative validation.

The main results of drivers' behavior turning a curve are:

- When distracted, drivers tend to pay less attention to driving tasks, and focus on the secondary task. This is achieved mainly by following the car ahead, keeping a safe headway, and reproducing its actions.

- As a result of this lack of attention to driving task, drivers did not notice the beginning of the curve while they were answering PASAT. It caused an delay in braking to complete the stretch of curve, with brakes being activated after the beginning of the curve.

- When aware of the driving task, drivers tried to achieve a high performance in the simulation. High performance means maximize the speed to complete the stretch in lower time but with safety conditions. This conclusion comes from the analysis of the speed developed in long tangents, generally above the mean speed developed in other stretches, and from a high braking rate ahead of curves to develop it. 
- Comparing the level of attention of the drivers to the environment and surroundings of the virtual scenario, it was concluded that drivers had a reduced field of view when they were distracted. It means that distracted drivers gaze and keep track only on the lane in front of them. When fully focused on the driving task, drivers' attention to the scenario's elements such as speedometers and rear mirrors increased significantly, as well as the attention to the surrounding scenario. The total of time that drivers spent looking at other elements in the projection (mirrors and speedometer) while attentive to driving task was twice as high as when they were distracted.

Results obtained in this proposal are valid only for the sample involved in the simulations. Due to limitations of sample selection, results do not represent the behavior of the whole population. Graduate students prevailed in the sample: younger drivers, of an average of 23 years old, and with drive permit for an average time of 5 years.

Drivers' behaviour in a real road cannot be inferred from behaviour obtained in driving simulations due to the amount of attention from drivers to the distraction task. While in a driving simulator participants prioritize the attention to PASAT with a significant loss in safety in the driving task, the same level of distraction could be seriously danger in a real situation. The changing in priority from PASAT to primary tasks only occurred when participants found themselves in a near collision risk situation. In real driving, drivers must prioritize primary tasks above all circumstances, as distracted driving may lead to serious accidents or fatalities. Drivers would not allow distraction at the same levels during real vehicle driving the way they were in a simulator.

Despite the lack of similarity on attention to answer PASAT in simulations and real driving, distraction in real driving activities may be caused by diverse situations not related to mental distraction, and drivers may not be aware of the dangers. Selection of music on radio or navigation systems or handling the mobile phones are known examples of harmful tasks derived from distraction and may be compared to PASAT results in distraction levels. 
Considering the aforementioned distractions, drivers are subject to serious accidents if distracted in the stretch analyzed for this thesis. Complementing, sections with high accident rates should be intensively signalized to ensure full attention of drivers for driving activity. This goal can be achieved by the use of rumble strips or traffic calming signaling.

Further conclusions of drivers' behavior were observed from simulations with different level of services:

- Despite total control in simulation and expected situations, it is not possible to predict constant traffic density for the whole simulation.

- For that reason, the traffic density supported in a simulator's software should be categorized in: free flow, reasonably free flow and synchronous flow.

- Car following flow cannot represent drivers' behavior, as drivers are behaving exactly like the vehicle ahead (under a headway limit). The comparison of drivers' behavior as proposed by this thesis could only be achieved in free flow traffic.

\subsection{FURTHER STUdIES AND SUGgeStIONS}

Under these considerations, additional questions about drivers' behavior have come to the forefront and can be investigated in future studies. At first, related to traffic flow in comparison to mental workload, new investigations may identify relations in free flow and reasonably free traffic, as drivers in simulators tend to focus on the distraction task and prefer car following situations for this action.

This proposal only considers one of the most dangerous curves in the whole simulated scenario. Further studies may also include diverse situations with different curve lengths and tangent sizes, as well as the influence of each of these aspects on the driving speed profile of the participants.

One last suggestion of further studies includes investigating the configuration of virtual drivers on roads, and their influence on participants' behavior. Virtual drivers are related to the behavior of the simulated traffic in the surrounding of the participants, how the vehicles near the participant may behave. Drivers can be 
defined as aggressive, peaceful, careful, or self-confident, for example, and parameter about their behavior can be set, as the level of accordance to signalling, level of hurry, if the vehicle will be conducted by a calm or aggressiveness driver, the ability to control the vehicle or the self-confidence of the driver in the activity. The behaviour of these virtual drivers around the participant can affect the way that drivers react to activities in the simulator. 


\section{BIBLIOGRAPHY}

AASHTO. Highway Safety Manual. Washington, DC: [s.n.], 2010.

ALLEN, R. W.; ROSENTHAL, T., J.; COOK, M. A short history of driving simulation. Handbook of driving simulation for engineering, medicine, and psychology. [S.1.]: CRC Press, 2011. p. 2-1; 2-11.

AUTOPISTA REGIS BITTENCOURT. Institucional. Disponível em: <http://www.autopistaregis.com.br/?link=institucional>. Acesso em: 9 set. 2015.

BEKIARIS, E.; AMDITIS, A.; PANOU, M. DRIVABILITY: a new concept for modelling driving performance. Cognition, Technology \& Work, v. 5, p. 152-161, 2003.

BIRD, R.; HASHIM, I. H. Operating Speed and Geometry Relationships for Rural Single Carriageways in the UK. 3rd International Symposium on Highway Geometric Design, v. 1, n. 0, p. 1-22, 2005.

BREHMER, B.; DÎRNER, D. Experiments with computer simulated microworlds: escaping both the narrox straits of the labiratory and the deep blue sea of the field study. computers in Human Behavior, v. 9 , p. 171-184, 1993.

BROWN, L. Perceptual Countermeasures: Experimental Research Perceptual Countermeasures : 1999.

CARSTEN, O. From driver models to modelling the driver: What do we really need to know about the driver? Modelling Driver Behaviour in Automotive Environments: Critical Issues in Driver Interactions with Intelligent Transport Systems. [S.1: s.n.], 2007. p. 105-120.

CASTIllo, M. Análise Da Percepção Da Sinalização Vertical Rodoviária Utilizando Um Ambiente Simulado De Direção. Um Estudo De Caso Na Rodovia Br-116. 2015. EESC - USP Universidade de São Paulo, 2015. 
CHAKROBORTY, P.; AGRAWAL, S.; VASISHTHA, K. Microscopic Modeling of Driver Behavior in Uninterrupted Traffic Flow. Journal of Transportation Engineering, v. 130, n. 4, p. 438-451, 2004.

COOPER, J. M. et al. An Investigation of Driver Distraction Near the Tipping Point of Traffic Flow Stability. v. 51, n. 2, p. 261-268, 2009.

CRUNDALL, D. et al. Eye movements and hazard perception in police pursuit and emergency response driving. Journal of experimental psychology. Applied, v. 9, n. 3, p. 163$174,2003$.

DE WAARD, D. The Measurement of Drivers 'Mental Workload. 1996. 198 f. Traffic Research Center Netherlands, $1996 . \quad$ Disponível em: <http://dissertations.ub.rug.nl/FILES/faculties/ppsw/1996/d.de.waard/09_thesis.pdf>.

DEPARTMENT OF TRANSPORT - ROAD SAFETY DIVISION OF SOUTH AFRICA. Arrive Alive. Disponível em: <www.arrivealive.co.za>. Acesso em: 3 fev. 2016.

DNER. Manual de Drenagem de Rodovias. Rio de Janeiro: [s.n.], 1990.

DUCHOWSKI, A. T. Eye Tracking Methodology. Theory and Practice. Second edition. [S.1: s.n.], $2007 . \quad$ Disponível em: <http://site.ebrary.com/lib/stanford/reader.action?docID=10202868>.

EDWARDS, J. B. Speed adjustment of motorway commuter traffic to inclement weather. Transportation Research Part F: Traffic Psychology and Behaviour. [S.1: s.n.]. Disponível em: <http://www.sciencedirect.com/science/article/pii/S1369847899000030>., 1999

EVANS, L. Human behavior feedback and traffic safety. Human Factors, v. 27, n. 5, p. 555576, 1985. Disponível em: <http://www.scopus.com/inward/record.url?eid=2-s2.00022143583\&partnerID=tZOtx3y1>.

EVANS, L. Traffic safety and the driver. [S.1: s.n.], 1991.

FITZPATRICK, K.; COLLINS, J. Speed-Profile Model for Two-Lane Rural Highways. Transportation Research Record: Journal of the Transportation Research Board, v. 1737, n. 1, p. 42-49, 2000. Disponível em: <http://trrjournalonline.trb.org/doi/10.3141/1737-06>. 
GELAU, C.; KREMS, J. F. The occlusion technique: A procedure to assess the HMI of invehicle information and communication systems. Applied Ergonomics, v. 35, n. 3, p. 185187, 2004. Disponível em: <http://www.ncbi.nlm.nih.gov/pubmed/15145280>.

GHADIRI, S. M. R. et al. Intelligent speed adaptation: Preliminary results of on-road study in Penang, Malaysia. IATSS Research, v. 36, n. 2, p. 106-114, 2013. Disponível em: <http://dx.doi.org/10.1016/j.iatssr.2012.08.001>.

GOODMANN, M. J. et al. Using cellular telephones in vehicles: Safe or unsafe? Transportation Human Factors, v. 1, n. 1, p. 3-42, 1999. Disponível em: <http://www.tandfonline.com/doi/abs/10.1207/sthf0101_2>.

GREEN, M. Skewed View: Accident Investigation. Occupational Health \& Safety Canada, 2003.

GRONWALL, D. M. A. Paced Auditory Serial-Addition Task: a Measure of Recovery From Concussion. Perceptual and Motor Skills, v. 44, n. 2, p. 367-373, 1977. Disponível em: <http://www.amsciepub.com/doi/abs/10.2466/pms.1977.44.2.367>.

HEINIJOKI, H. Kelin kokemisen, rengaskunnon ja rengastyypin vaikutus nopeuskä yttäytymiseen. Tielaitos, Liikenteen palvelukeskus, 1994.

HICKS, T. G.; WIERWILlE, W. W. Comparison of Five Mental Workload Assessment Procedures in a Moving-Base Driving Simulator. Human Factors: The Journal of the Human Factors and Ergonomics Society, v. 21, n. 2, p. 129-143, 1979. Disponível em: <http://hfs.sagepub.com/content/21/2/129.short>.

HOLLANDS, J. G.; WICKENS, C. D. Engineering psychology and human performance. Journal of surgical oncology, 1999.

INAGAKI, T. Towards monitoring and modelling for situation-adaptive driver assist systems. Modelling Driver Behaviour in Automotive Environments: Critical Issues in Driver Interactions with Intelligent Transport Systems. [S.1: s.n.], 2007. p. 43-57.

JAMSON, H. Cross-Platform Validation Issues. Handbook of Driving Simulation for Engineering, Medicine, and Psychology. [S.1: s.n.], 2011. p. 12.1-12.13. 
JOHNSON, A.; PROCTOR, R. Attention: Theory and Practice. 2455 Teller Road, Thousand Oaks California 91320 United States: SAGE Publications, Inc., 2004. Disponível em: <http://books.google.es/books?id=Wwu4W_aO8oAChttp://sk.sagepub.com/books/attention>.

KANTOWITZ, B. H. Selecting measures for human factors research. Human factors, v. 34, n. 4, p. 387-398, 1992.

KANTOWITZ, B. H. Using Driving Simulators Outside of North America. Handbook of Driving Simulation for Engineering , Medicine , and Psicology., p. 3-1, 3-14, 2011.

KANTOWITZ, B. H.; SIMSEK, O. Secondary-task measures of driver workload. Stress, workload and fatigue, p. 395-408, 2001.

KERNER, B. S. The Physics of Traffic. [S.1.]: Springer US, 2004. v. 26. Disponível em: <http://link.springer.com/10.1007/978-3-540-40986-1>.

KILPELÄINEN, M.; SUMMALA, H. Effects of weather and weather forecasts on driver behaviour. Transportation Research Part F: Traffic Psychology and Behaviour, v. 10, n. 4, p. 288-299, 2007.

KLAUER S. G., DINGUS T. A., NEALE V. L., SUDWEEKS J., R. D. J. The impact of driver inattention on near-crash/crask risk. An analysis using the 100-Car Naturalistic Driving Study Data. Blacksburg: Virginia Tech Transportation Institute, 2006.

KOTTERBA, S. et al. Assessment of driving performance in patients with relapsing-remitting multiple sclerosis by a driving simulator. European Neurology, v. 50, n. 3, p. 160-164, 2003.

LAMBLE, D. et al. Cognitive load and detection thresholds in car following situations. Safety implications for using mobile (cellular) telephones while driving, v. 31, n. 6, p. 617-624, 1999.

LEHTONEN, E.; LAPPI, O.; SUMMALA, H. Anticipatory eye movements when approaching a curve on a rural road depend on working memory load. Transportation Research Part F: Traffic Psychology and Behaviour, v. 15, n. 3, p. 369-377, 2012. Disponível em: <http://dx.doi.org/10.1016/j.trf.2011.08.007>. 
LEI, S.; WELKE, S.; ROETTING, M. Driver's Mental Workload Assessment Using EEG Data in a Dual Task Paradigm. International Technical Conference on the Enhanced Safety of Vehicles, p. 1-8, 2009.

LEWIS, J. R.; SAURO, J. The factor structure of the system usability scale. Lecture Notes in Computer Science (including subseries Lecture Notes in Artificial Intelligence and Lecture Notes in Bioinformatics), v. 5619 LNCS, n. 3, p. 94-103, 2009.

MEIJMAN, T. F. Over vermoeidheid: arbeidspsychologische studies naar beleving van belastingseffecten. [Fatigue: studies on the perception of workload effects](Dissertation). 1991. Amsterdam: University of Amsterdam, 1991.

MEISTER, D. Behavioral Foundations of System Development. 1976.

MICHON, J. A critical view of driver behaviour models: What do we know, what should we do? Boston, MA: Springer US, 1985. Disponível em: <http://link.springer.com/chapter/10.1007/978-1-4613-2173-6_19>.

NEYENS, D. M.; BOYLE, L. N. The effect of distractions on the crash types of teenage drivers. Accident Analysis and Prevention, v. 39, n. 1, p. 206-212, 2007.

PANOU, M.; BEKIARIS, E.; PAPAKOSTOPOULOS, V. Modelling Driver Behaviour in European and International Projects. Modelling Driving Behaviour in Automotive Environments. [S.1.]: Springer US, 2006. p. 440.

PAPACOSTAS, C. S.; PREVEDOUROS, P. D. Transportation Engineering and Planning. [S.1.]: Prentice Hall, 2005.

PARKES, A. M. Data capture techniques for RTI usability evaluation. In Commission of the European Communities, Advanced telematics in road transport, Proceedings of the DRIVE conference, p. 1440-1456, 1991.

PEW, R. W. Secondary tasks and workload measurement. Mental Workload. [S.1: s.n.], 1979. p. 23-28. 
PRADHAN, A. K. et al. Measuring Young Drivers' Behaviors during Complex Driving Situations. Proceedings of the seventh international driving symposium on human factors in driver assessment, training and vehicle design, v. 1, p. 460, 466, 2013. Disponível em: <http://drivingassessment.uiowa.edu/sites/default/files/DA2013/Papers/070_Pradhan_0.pdf>.

QUIMBY, A.; DOWNING, C. Road users' attitudes to some road safety and transportation issues. [S.1: s.n.], 1991.

RAO, S. M. et al. Correlation of magnetic resonance imaging with neuropsychological testing in multiple sclerosis. Neurology, v. 39, p. 161-166, 1989.

RASMUSSEN, J. Information Processing and Human-Machine Interaction. An Approach to Cognitive Engineering. [S.1: $\quad$ s.n.], 1986. Disponível em: <http://www.citeulike.org/group/1480/article/794973>.

REASON, J. Human error: models and management. West J Med, v. 172, n. 6, p. 393-396, 18 mar. 2000. Disponível em: <http://www.ncbi.nlm.nih.gov/pubmed/10854390>.

RECARTE, M. A.; NUNES, L. M. Driver distractions. Human factors of visual and cognitive performance in driving. [S.1: s.n.], 2009. p. 75-89. Disponível em: $<$ http://books.google.com/books?hl=en\&lr=\&id=hjEqGfVXzJoC\&oi=fnd\&pg=PA75\&dq="p rocessing, + and + action. + A + great + effort + was + made + to + implement + the" + " (the + Argos + instru mented+vehicle),+allowing+realistic+onroad"+"several+hours+per+driver+of+continuous+and+accurat $>$.

ROYAN, J. et al. The Adjusting-Paced Serial Addition Test (Adjusting-PSAT): Thresholds for speed of information processing as a function of stimulus modality and problem complexity. Archives of Clinical Neuropsychology, v. 19, n. 1, p. 131-143, 2004.

SAHAMI, S.; SAYED, T. How drivers adapt to drive in driving simulator, and what is the impact of practice scenario on the research? Transportation Research Part F: Traffic Psychology and Behaviour, v. 16, p. 41-52, 2013. Disponível em: <http://dx.doi.org/10.1016/j.trf.2012.08.003>. 
SAMPSON, H. Pacing and performance on a serial addition task. Canadian Journal of Psychology/Revue canadienne ..., v. 10, n. 4, p. 219-225, 1956. Disponível em: <http://psycnet.apa.org/journals/cep/10/4/219/>.

SARTORI, F. et al. Análise da Fixação Ocular de condutores através de teste de carga mental. 2015, Ouro Preto/MG: [s.n.], 2015. p. $1402-1413$.

SHERIDAN, T. B. Musings on telepresence and virtual presence. Presence Teleoperators and Virtual Environments, v. 1, p. 120-126, 1992. Disponível em: <http://dl.acm.org/citation.cfm?id=128947.128956>.

TREAT, J. R. et al. Causes of Road Accidents. Bmj, v. 1, n. 4975, p. 1098-1099, 1956. Disponível em: <http://www.bmj.com/cgi/doi/10.1136/bmj.1.4975.1098>.

TSIMHOMI, O.; GREEN, P. Visual occlusion to assess the demands of driving tasks: the Literature. 2001, Michigan: [s.n.], 2001. p. 1-18. Disponível em: <http://www.umich.edu/ driving/occlusionworkshop2001/papers/OW2001_Green.pdf>.

VAN DER HORST, R. Occlusion as a measure for visual workload: An overview of TNO occlusion research in car driving. Applied Ergonomics, v. 35, p. 189-196, 2004.

VÁRHELYI, A. Drivers' speed behaviour at a zebra crossing: A case study. Accident Analysis and Prevention, v. 30, n. 6, p. 731-743, 1998.

WAARD, D. DE; BROOKHUIS, K. A. On the measurement of driver workload. Traffic \& Transportation Psychology. Theory and Application, p. 161-171, 1997.

WITMER, B. G.; SINGER, M. J. Measuring Presence in Virtual Environments: A Presence Questionnaire. Presence: Teleoper. Virtual Environ., v. 7, n. 3, p. 225-240, 1998. Disponível em: 〈http://www.mitpressjournals.org/doi/abs/10.1162/105474698565686>.

YOUNG, L. R.; SHEENA, D. Survey of eye movement recording methods. Behavior Research Methods \& Instrumentation, v. 7, n. 5, p. 397-429, 1975. 
Scientific Production

\section{Complete works published in proceedings of conferences}

SARTORI, F. V.; TORQUATO, T.; LAROCCA, A. P. C.; SIMÕES, A. Análise da Fixação Ocular de condutores através de teste de carga mental. In: ANPET, Ouro Preto/MG.XXIX Congresso Nacional de Pesquisa em Transportes da ANPET. Ouro Preto/MG: 2015.

\section{Summary published in proceedings of conferences}

SARTORI, F. V.; LAROCCA, A. P. C.; ALMQVIST, R.; O Simulador De Direção Veicular E O Processo De Habilitação Do Condutor No Brasil: Estudos De Validação E Proposta De Melhoria. In: ANPET, Curitiba/PR. XXIII Congresso Nacional de Pesquisa em Transportes da ANPET. Curitiba/PR. 2014.

\section{Articles submitted to Scientific Journals}

SARTORI, F. V., LAROCCA, A. P. C.; Drivers' speed profile at curves under distraction task. Transportation Research Part F: Traffic Psychology and Behaviour. in prelo. 



\section{ANNEX A - INSTRUCTIONS FOR THE PASAT}

\section{DESCRIPTION}

The Paced Auditory Serial Addition Test (PASAT) is a measure of cognitive function that specifically assesses auditory information processing speed and flexibility, as well as calculation ability. It was initially developed by Gronwall (1977) to monitor the recovery of patients who had sustained mild head injuries. Stimulus presentation rates were adapted for use with MS patients by Rao et al. (1989), and the measure has been widely used in MS studies during the last decade. The PASAT is presented on audiocassette tape or compact disk to control the rate of stimulus presentation. Single digits are presented either every 3" (3" PASAT) or every 2" (2" PASAT) and the patient must add each new digit to the one immediately prior to it. The test result is the number of correct sums given (out of 60 possible). To minimize familiarity with stimulus items in clinical trials and other serial studies, two alternate forms have been developed; the order of these should be counterbalanced across testing sessions.

\section{MATERIALS NEEDED}

An audiocassette tape or CD player, audiocassette tape or CD with PASAT stimuli, clipboard and PASAT Record Forms to administer the test.

\section{DISCONTINUE RULES}

1. If the patient cannot get at least two answers correct (consecutive or not) on any one of the three 3" practice sequences.

2. If the patient cannot get at least one answer correct on PASAT-3" test, do not administer the 2" test. This patient is considered unable to perform the test.

ADMINISTRATION 
Verify that you have the correct Record Form (Form A or B) before you start reading the instructions for the 3" Practice Trial to the patient.

PASAT-3" Practice Trials

For Part 1 (stimuli every 3.) say, "On this tape you are going to hear a series of single digit numbers that will be presented at the rate of one every 3 seconds. Listen for the first two numbers, add them up, and tell me your answer. When you hear the next number, add it to the one you heard on the tape right before it. Continue to add the next number to each preceding one. Remember, you are not being asked to give me a running total, but rather the sum of the last two numbers that were spoken on the tape."

Then give the following example: "For example, if the first two numbers were ' 5 ' and '7,' you would say '12.' If the next number were '3,' you would say '10.' Then if the next number were '2,' you would say '5.' If the patient is having difficulty understanding these instructions, write $5,7,3$, and 2 on a sheet of paper and repeat the instructions, demonstrating how the task is done.

Then say, "This is a challenging task. If you lose your place, just jump right back in - listen for two numbers in a row and add them up and keep going. There are some practice items at the beginning of the tape. Let's try those first." Play the sample items, stopping the tape after the last practice item. Repeat the practice items, if necessary, until the subject understands the instructions (up to three times). You should always administer at least one practice trial before administering the actual test. If the patient begins to give you a running total, stop the practice immediately and explain the task again, emphasizing that he/she is not to give you a running total. Then start the practice items again from the beginning. If the patient begins adding each number to the number two previous to it, again stop the practice immediately, explain the correct way to do the task, and start the practice items from the beginning. If the patient merely makes a math error, do not stop the tape; continue with the practice items. After two consecutive "no responses" prompt him/her to resume by saying, "Jump back in with the next two numbers you hear." 
Administer the practice sequence a maximum of three times. Record answers in the space provided on the back of the PASAT Record Form.

\section{PASAT-3"}

Once it is clear that the patient possesses sufficient understanding of the task, begin Part 1. Before starting Part 1, remind him/her: "Remember, if you get lost, just jump back in because I can't stop the test once it has begun." Discourage talking and oral calculations during the test; only the patient's answers should be spoken out loud. The patient may need prompting to continue the test if she/he gets lost. After five consecutive "no responses" redirect the patient quickly by saying, “Jump back in," but do not stop the tape.

PASAT-2" Practice Trials

Before Part 2 (stimuli every 2") say, “There is a second part to this test, identical to the first, except that the numbers will come a little faster, one every 2 seconds. Let's try some practice items." Emphasize that the patient's task is the same but that it is important to try to get his/her answer out as quickly as possible so as to hear the next number spoken on the tape. Every visit, at least one 2" Practice trial must be administered before administering the 2" test. Allow up to three practice trials.

\section{PASAT-2"}

After the practice items, proceed directly with the 2" administration. If the patient completed the 3" PASAT, the 2" version is to be administered regardless of the patient's performance on the 2 " practice items.

Completing the PASAT Record Form

Place a check next to all correct answers. Write in any incorrect responses in the space provided. Place a dash when no response was given. If the patient corrects him/herself after giving a response, count the amended answer as the response. The amended response is the one that will be used in determining total correct, regardless of whether it was the correct or incorrect response. Slash through the old response and write in 'SC' with a circle around it to indicate that the patient selfcorrected. Each section of the PASAT has a maximum of 60 correct answers (i.e. 61 
digits are presented for each part). Count the total number correct (number of circled answers) for PASAT-3" and record on the PASAT Record Form. Repeat the same scoring procedure for PASAT-2". (Additional scores can also be computed to examine patterns of responses on the PASAT, but these are beyond the scope of this manual.)

Finally, record any circumstances that you believe may have affected the patient's performance. These are factors that may have affected the trial, but were not severe enough to necessitate repetition of the trial. Examples include, but are not limited to, the following:

- Subtle noises outside of the testing room

- Patient reports frustration or mild distress

- Patient talked during test (other than to give answers)

If a trial must be repeated, indicate this and specify the reason why it had to be repeated. Examples of reasons to repeat a trial include, but are not limited to the following:

- Test interrupted (e.g. someone walked into the room or other major disturbance)

- Examiner error, such as starting the tape in the wrong place or using the wrong form.

Record only totals for the successfully completed PASAT-3" and PASAT-2". If the patient is unable to perform the PASAT (i.e., cannot get at least two correct on any 3 . Practice and at least one correct on the test portion), the examiner should indicate "unable to complete due to cognitive limitations" and record any specific observations. If the patient did not complete a trial for any other reason, record the reasons for this as well (e.g., patient refused to complete test, examiner forgot to administer PASAT2", etc.). 
ANNEX B - PASAT FORM

PASAT - Form A

Name

Date

PRACTICE

\begin{tabular}{|l|l|l|l|l|l|l|l|l|l|}
\hline $9+1$ & 3 & 5 & 2 & 6 & 4 & 9 & 7 & 1 & 4 \\
10 & 4 & 8 & 7 & 8 & 10 & 13 & 16 & 8 & 5 \\
\hline
\end{tabular}

RATE \#1

$\left(3^{n}\right)$

\begin{tabular}{|c|c|c|c|c|c|c|c|c|c|}
\hline $\begin{array}{l}1+4 \\
5 \\
\end{array}$ & $\begin{array}{l}8 \\
12 \\
\end{array}$ & $\begin{array}{l}1 \\
9 \\
\end{array}$ & $\begin{array}{l}5 \\
6 \\
\end{array}$ & $\begin{array}{l}1 \\
6 \\
\end{array}$ & $\begin{array}{l}3 \\
4 \\
\end{array}$ & $\begin{array}{l}7 \\
10 \\
\end{array}$ & $\begin{array}{l}2 \\
9 \\
\end{array}$ & $\begin{array}{l}6 \\
8 \\
\end{array}$ & $\begin{array}{l}9 \\
15\end{array}$ \\
\hline 4 & 7 & 3 & 5 & 3 & 6 & 8 & 2 & 5 & 1 \\
\hline 13 & 11 & 10 & 8 & 8 & 9 & 14 & 10 & 7 & 6 \\
\hline 5 & 4 & 6 & 3 & 8 & 1 & 7 & 4 & 9 & 3 \\
\hline $6-$ & $9-$ & 10 & $9-$ & 11 & 9 & 8 & 11 & 13 & 12 \\
\hline 7 & 2 & 6 & 9 & 5 & 2 & 4 & 8 & 3 & 1 \\
\hline 10 & 9 & 8 & 15 & 14 & 7 & 6 & 12 & 11 & 4 \\
\hline 8 & 5 & 7 & 1 & 8 & 2 & 4 & 9 & 7 & 9 \\
\hline 9 & 13 & 12 & 8 & 9 & 10 & 6 & 13 & 16 & 16 \\
\hline 3 & 1 & 5 & 7 & 4 & 8 & 1 & 3 & 8 & 2 \\
\hline 12 & 4 & 6 & 12 & 11 & 12 & 9 & 4 & 11 & 10 \\
\hline
\end{tabular}

Total Correct (raw) =

Percent Correct $=$

PRACTICE

\begin{tabular}{|l|l|l|l|l|l|l|l|l|l|}
\hline $3+8$ & 2 & 7 & 9 & 1 & 8 & 5 & 2 & 6 & 4 \\
$11-$ & $10 \ldots$ & 9 & 16 & $10 \ldots$ & 9 & $13 \ldots$ & 7 & 8 & 10 \\
\hline
\end{tabular}

RATE \#2

$\left(2^{\prime \prime}\right)$

\begin{tabular}{|c|c|c|c|c|c|c|c|c|c|}
\hline $\begin{array}{l}4+3 \\
7 \\
\end{array}$ & $\begin{array}{l}7 \\
10 \\
\end{array}$ & $\begin{array}{l}2 \\
9 \\
\end{array}$ & $\begin{array}{l}5 \\
7 \\
\end{array}$ & $\begin{array}{l}1 \\
6 \\
\end{array}$ & $\begin{array}{l}8 \\
9 \\
\end{array}$ & $\begin{array}{l}6 \\
14 \\
\end{array}$ & $\begin{array}{l}9 \\
15\end{array}$ & $\begin{array}{l}1 \\
10\end{array}$ & $\begin{array}{l}7 \\
8\end{array}$ \\
\hline 9 & 4 & 6 & 3 & 5 & 8 & 1 & 6 & 2 & 7 \\
\hline 16 & 13 & 10 & 9 & 8 & 13 & 9 & 7 & 8 & 9 \\
\hline 5 & 9 & 4 & 5 & 2 & 6 & 4 & 8 & 3 & 5 \\
\hline 12 & 14 & 13 & $9-$ & 7 & 8 & 10 & 12 & 11 & 8 \\
\hline 9 & 7 & 4 & 2 & 8 & 5 & 2 & 1 & 6 & 4 \\
\hline 14 & 16 & 11 & 6 & 10 & 13 & 7 & 3 & 7 & 10 \\
\hline 7 & 3 & 5 & 9 & 6 & 4 & 5 & 3 & 9 & 4 \\
\hline 11 & 10 & 8 & 14 & 15 & 10 & 9 & 8 & & \\
\hline 1 & 8 & 3 & 1 & 6 & 8 & 5 & 4 & 2 & 6 \\
\hline 5 & 9 & 11 & 4 & 7 & 14 & 13 & 9 & 6 & 8 \\
\hline
\end{tabular}

Total Correct (raw) =

Percent Correct $=$ 



\section{Annex C - Questionário de CaracterizaÇÃo do Condutor}

Prezado participante

Inicialmente gostaríamos de agradecer sua participação no experimento de Avaliação do Comportamento de Condutores em Ambientes Simulados. Por meio deste, pedimos o seu consentimento para usar os resultados do trabalho em publicações futuras. Ressaltamos que seus dados pessoais nunca serão divulgados, sendo apenas utilizados para caracterização dos grupos de amostra.

Segue abaixo questões que serão utilizadas para o prosseguimento de nossos estudos:

1) O que te motivou a participar do experimento?

2) „Numa semana da sua rotina habitual, quantos dias você dirige por semana?
( ) Nenhum dia ( ) 1 a 3 dias
( ) 4 a 6 dias
( ) Todos os dias

3) Num dia da sua rotina habitual, quantas vezes por dia você dirige?
( ) Não dirijo
( ) 1 ou 2 vezes
( ) 3 a 5 vezes
( ) Mais de 6 vezes

4) Num dia da sua rotina habitual, quanto tempo por dia você dirige?

( ) Não dirijo ( ) Até $30 \mathrm{~min}$ （）Até 2 horas （）Mais de 2 horas

5) Você se considera um condutor:

( ) Experiente ( ) Inexperiente

6) Quais características melhor descrevem o tipo de condutor que você é?
( ) Inseguro
( ) Cauteloso
( ) Confiante
( ) Agressivo 
7) Você já levou multas de trânsito?

( ) Não

( ) Sim.

- Considerando as multas cometidas nos últimos 12 meses, quais foram:

( ) Infrações leves. Quantas?

( ) Infrações médias. Quantas?

( ) Infrações graves. Quantas?

( ) Infrações gravíssimas. Quantas?

8) Como condutor você já se envolveu em acidentes de trânsito?

( ) Não

( ) Sim, em batidas leves. Quantas?

( ) Sim, em acidentes com vítimas. Quantos?

9) Já participou de outras simulações com cockpit e manopla de comandos do tipo Racing wheels?

( ) $\operatorname{Sim}$ ( ) Não

10) Você habitualmente joga no celular, computador ou consoles?

( ) Sim ( ) Não

- Se joga, com que frequência?

( ) Diariamente

( ) Algumas vezes por semana

( ) Algumas vezes por mês

( ) Raramente

- Você se entretém com jogos de corrida ou carros? Com que frequência?

( ) Diariamente

( ) Algumas vezes por semana

( ) Algumas vezes por mês

( ) Raramente 
Idade:

Categoria da Habilitação:

Tempo de Habilitação:

Experiência em trecho urbano:

Experiência em pista dupla:

Experiência em pista simples:

Data

Assinatura 


\section{ANNEX D - CARACTERIZAÇÃo DE IMERSÃo NO SimULADOR}

Caracterize sua experiência na simulação, marcando um " $x$ " em um dos 7 campos que melhor traduz a sua sensação durante o experimento. Por favor, considere toda a escala quando assinalar as respostas, inclusive os níveis intermediários. Responda as questões na ordem apresentada, sem pular ou alterar uma resposta após assinalá-la.

COM RELAÇÃO À SUA EXPERIÊNCIA NA SIMULAÇÃO...

1. Quanto você conseguiu controlar o veículo simulado?

\begin{tabular}{|l|l|l|l|l|l|}
\hline $\begin{array}{l}\text { Nenhum } \\
\text { controle }\end{array}$ & & Algum controle & & & Controle total \\
\hline
\end{tabular}

2. Qual o nível de realidade sentida, em função das respostas do simulador, para suas ações?

\begin{tabular}{|l|l|l|l|l|l|l|}
\hline Não respondeu & & $\begin{array}{l}\text { Resposta } \\
\text { moderada }\end{array}$ & & & $\begin{array}{c}\text { Respondeu } \\
\text { completamente }\end{array}$ \\
\hline
\end{tabular}

3. Qual o nível de naturalidade com o qual você interagiu com o simulador?

\begin{tabular}{|c|l|l|l|l|l|l|}
\hline $\begin{array}{c}\text { Extremamente } \\
\text { artificial }\end{array}$ & & Médio & & & $\begin{array}{c}\text { Completamente } \\
\text { natural }\end{array}$ \\
\hline
\end{tabular}

4. Em que nível o aspecto visual (apenas) do simulador conseguiu te envolver no ambiente?

\begin{tabular}{|l|l|l|l|l|l|}
\hline Nenhum & & $\begin{array}{c}\text { Envolvimento } \\
\text { mediano }\end{array}$ & & Completamente \\
\hline
\end{tabular}

5. Quão natural foi o seu controle dos mecanismos de direção do simulador?

\begin{tabular}{|c|l|l|l|l|l|l|}
\hline $\begin{array}{c}\text { Extremamente } \\
\text { artificial }\end{array}$ & & & Médio & & & $\begin{array}{c}\text { Completamente } \\
\text { natural }\end{array}$ \\
\hline
\end{tabular}


6. Qual o nível de convicção que você daria para os objetos presentes na simulação?

\begin{tabular}{|c|l|l|l|l|l|l|}
\hline Nenhuma & & & $\begin{array}{c}\text { Convicção } \\
\text { mediana }\end{array}$ & & & $\begin{array}{c}\text { Completamente } \\
\text { convincente }\end{array}$ \\
\hline
\end{tabular}

7. Qual o nível de coerência que você daria ao comparar o ambiente simulado com uma experiência de direção real?

\begin{tabular}{|l|l|l|l|l|l|l|}
\hline $\begin{array}{l}\text { Nenhuma } \\
\text { coerência }\end{array}$ & & Base coerente & & & $\begin{array}{c}\text { Completamente } \\
\text { idêntico }\end{array}$ \\
\hline
\end{tabular}

8. Quantas vezes você foi capaz de prever o que aconteceria logo após executar alguma ação no simulador? (Rotacionar o volante, acionar os freios...)

\begin{tabular}{|l|l|l|l|l|l|l|}
\hline Nenhuma vez & & & Algumas vezes & & & Todas as vezes \\
\hline
\end{tabular}

9. Quanto você conseguiu monitorar e explorar visualmente o ambiente e tomar decisões baseadas no entorno?

\begin{tabular}{|c|l|l|l|l|l|l|}
\hline $\begin{array}{c}\text { Nenhum } \\
\text { monitoramento }\end{array}$ & & $\begin{array}{c}\text { Algum } \\
\text { monitoramento }\end{array}$ & & & $\begin{array}{c}\text { Monitoramento } \\
\text { constante }\end{array}$ \\
\hline
\end{tabular}

10. Quantos detalhes que você foi capaz de identificar nos objetos ao observálos?

\begin{tabular}{|l|l|l|l|l|l|l|}
\hline $\begin{array}{l}\text { Nenhum } \\
\text { detalhe }\end{array}$ & & & Alguns detalhes & & & Muitos detalhes \\
\end{tabular}

11. Considerando um mesmo objeto a diferentes distâncias, você percebeu diferença no nível de detalhamento?

\begin{tabular}{|l|l|l|l|l|l|l|}
\hline $\begin{array}{l}\text { Nenhuma } \\
\text { diferença }\end{array}$ & & & $\begin{array}{c}\text { Alguma } \\
\text { diferença }\end{array}$ & & & Muita diferença \\
\hline
\end{tabular}


12. Quão envolvido com o ambiente virtual você esteve?

\begin{tabular}{|c|l|l|l|l|l|l|}
\hline $\begin{array}{c}\text { Nenhum } \\
\text { envolvimento }\end{array}$ & & Alguma relação & & & $\begin{array}{c}\text { Completamente } \\
\text { absolvido }\end{array}$ \\
\hline
\end{tabular}

13. Quanto tempo de atraso você encontrou entre uma ação tomada e a resposta do simulador?

\begin{tabular}{|l|l|l|l|l|l|}
\hline Nenhum atraso & & $\begin{array}{c}\text { Atrasos } \\
\text { toleráveis }\end{array}$ & & Respostas \\
lentas
\end{tabular}

14. Quanto tempo você demorou para se adaptar ao simulador?

\begin{tabular}{|c|c|c|c|c|c|c|}
\hline $\begin{array}{l}\text { Menos de } 1 \\
\text { minuto }\end{array}$ & $\begin{array}{l}\text { Menos de } 5 \\
\text { minutos }\end{array}$ & $\begin{array}{c}\text { Ao fim do } \\
\text { cenário teste }\end{array}$ & $\begin{array}{l}\text { Apenas na } 1^{\text {a }} \\
\text { volta }\end{array}$ & $\begin{array}{l}\text { Ao fim da } 1^{0} \\
\text { volta }\end{array}$ & $\begin{array}{c}\text { Apenas na } 2^{\mathrm{a}} \\
\text { volta }\end{array}$ & Não me adaptei \\
\hline
\end{tabular}

15. No fim do experimento, como você classificaria seu nível de aptidão para dirigir no simulador?

\begin{tabular}{|c|l|l|l|l|c|}
\hline Não consigo & & $\begin{array}{c}\text { Razoávelmente } \\
\text { experiente }\end{array}$ & & & $\begin{array}{c}\text { Bastante } \\
\text { competente }\end{array}$ \\
\hline
\end{tabular}

16. Quanto à qualidade da resolução do vídeo, esse te distraiu ou não permitiu que você realizasse a tarefa?

\begin{tabular}{|c|l|l|l|l|l|c|}
\hline Não interferiu & & $\begin{array}{c}\text { Interferiu de } \\
\text { alguma forma }\end{array}$ & & & $\begin{array}{c}\text { Não consegui } \\
\text { realizar tarefas }\end{array}$ \\
\hline
\end{tabular}

17. Quanto aos mecanismos de direção do cockpit, esses interferiram, ou não permitiram, que você conseguisse realizar alguma tarefa?

\begin{tabular}{|c|c|c|c|c|c|}
\hline Não interferiu & & $\begin{array}{c}\text { Interferiu de } \\
\text { alguma forma }\end{array}$ & & $\begin{array}{c}\text { Não consegui } \\
\text { comandar }\end{array}$ \\
\hline
\end{tabular}


18. Quanto você conseguiu se concentrar efetivamente na direção, ao invés de desviar a atenção para os mecanismos de direção?

\begin{tabular}{|c|l|l|l|l|l|l|}
\hline $\begin{array}{c}\text { Desviei muito a } \\
\text { atenção }\end{array}$ & Algumas vezes & & & $\begin{array}{c}\text { Totalmente } \\
\text { concentrado }\end{array}$ \\
\hline
\end{tabular}

19. Em que nível o aspecto auditivo (apenas) conseguiu te envolver no ambiente?

\begin{tabular}{|l|l|l|l|l|l|l|}
\hline Nenhum & & $\begin{array}{c}\text { Algum } \\
\text { envolvimento }\end{array}$ & & & Completamente \\
\hline
\end{tabular}

20. Quão bem você conseguiu identificar os sons?

\begin{tabular}{|c|c|c|c|l|l|l|}
\hline Não identifiquei & & & $\begin{array}{c}\text { Identifiquei } \\
\text { alguns }\end{array}$ & & & $\begin{array}{c}\text { Identifiquei } \\
\text { claramente }\end{array}$ \\
\hline
\end{tabular}

21. Quão bem você conseguiu identificar as origens dos sons?

\begin{tabular}{|c|c|c|c|c|c|c|}
\hline Não identifiquei & & & $\begin{array}{c}\text { Identifiquei } \\
\text { alguns }\end{array}$ & & & $\begin{array}{c}\text { Identifiquei } \\
\text { todos }\end{array}$ \\
& & & & & & \\
\hline
\end{tabular}


